Published in final edited form as:

Adv Exp Med Biol. 2019 ; 1175: 45-91. doi:10.1007/978-981-13-9913-8_3.

\title{
Physiology of Astroglia
}

\author{
Alexei Verkhratsky, \\ Faculty of Biology, Medicine and Health, The University of Manchester, Manchester M13 9PT, UK \\ Faculty of Health and Medical Sciences, Center for Basic and Translational Neuroscience, \\ University of Copenhagen, 2200 Copenhagen, Denmark \\ Achucarro Center for Neuroscience, IKERBASQUE, Basque Foundation for Science, 48011 \\ Bilbao, Spain \\ Vladimir Parpura \\ Department of Neurobiology, The University of Alabama at Birmingham, Birmingham, AL, USA

\section{Nina Vardjan, Robert Zorec} \\ Laboratory of Neuroendocrinology-Molecular Cell Physiology, Faculty of Medicine, Institute of \\ Pathophysiology, University of Ljubljana, Ljubljana, Slovenia \\ Celica Biomedical, Ljubljana, Slovenia
}

\section{Abstract}

Astrocytes are principal cells responsible for maintaining the brain homeostasis. Additionally, these glial cells are also involved in homocellular (astrocyte-astrocyte) and heterocellular (astrocyte-other cell types) signalling and metabolism. These astroglial functions require an expression of the assortment of molecules, be that transporters or pumps, to maintain ion concentration gradients across the plasmalemma and the membrane of the endoplasmic reticulum. Astrocytes sense and balance their neurochemical environment via variety of transmitter receptors and transporters. As they are electrically non-excitable, astrocytes display intracellular calcium and sodium fluctuations, which are not only used for operative signalling but can also affect metabolism. In this chapter we discuss the molecules that achieve ionic gradients and underlie astrocyte signalling.

\section{Keywords}

Astrocytes; Brain homoeostasis; Neurotransmitter receptors; Ion channels; SLC transporters; $\mathrm{Ca}^{2+}$ signaling; $\mathrm{Na}^{+}$signalling

\subsection{Definition of Astroglia}

Astroglia (also known as astrocytes) are a class of neural cells of ectodermal, neuroepithelial origin that sustain homeostasis and provide for defence of the central nervous system (CNS)

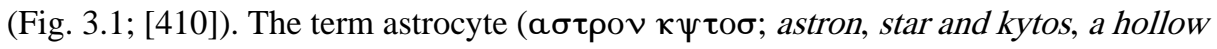

A. Verkhratsky Alexej.Verkhratsky@manchester.ac.uk. 
vessel, later cell; that is a star-like cell) was introduced by Michael von Lenhossék in 1895 [213]; of note, he proposed to name all parenchymal glia spongiocytes, with only a subtype of these cells having characteristic morphology in Golgi's stained preparations being identified as astrocyte. On this matter Lenhossék wrote: 'I would suggest that all supporting cells be named spongiocytes. And the most common form in vertebrates be named spider cells or astrocytes, and use the term neuroglia only cum grano salis (with a grain of salt), at least until we have a clearer view'. The terms of protoplasmic (white matter) and fibrous (grey matter) glia were introduced by Albert von Kölliker and William Lloyd Andriezen [13, 195]).

Astrocytes demonstrate quite heterogeneous morphology across different brain structures (see Chap. 1). Nevertheless, the main physiological features of astroglial cells are somewhat similar, being specifically tailored for their homeostatic function. Astrocytes maintain homeostasis of the CNS at all levels of organisation [408-410] from molecular (ion and transmitter homeostasis, regulation of $\mathrm{pH}$, metabolic energy support, Fig. 3.1), cellular (neurogenesis), network (synaptogenesis and synaptic maturation, maintenance and extinction), organ (regulation of the blood-brain barrier, operation of the glymphatic system) and systemic (chemosensing of oxygen, $\mathrm{CO}_{2}$ and systemic $\mathrm{Na}^{+}$concentration).

In the CNS, astrocytes are integrated into cellular networks (known as syncytia), by gap junctions, which are specialised areas of apposing membranes of adjacent cells pierced by many hundreds of intercellular channels or connexons that form the conduit for intercellular transport of ions, second messengers and other biologically active molecules with a molecular weight lesser than $1000 \mathrm{Da}$. In the mammalian CNS, astroglial syncytia are anatomically segregated within different anatomical structures. In the sensory cortex, astroglial syncytia are confined to individual barrels and in the olfactory bulb to individual glomeruli [118, 148, 332]. Panglial syncytia that connect astrocytes and oligodendrocytes have been identified in the thalamus, neocortex and hippocampus [59, 123, 181, 296]. Whether astroglia form syncytia with neurones, remains an open issue.

\subsection{Membrane Physiology and Ion Distribution}

Astrocytes are electrically non-excitable cells, with a rather negative resting membrane potential $\left(\mathrm{V}_{\mathrm{m}}\right)$ of about $-80 \mathrm{mV}$. Disparity between cytosolic and extracellular ion concentrations (Fig. 3.2), together with the specific membrane ion permeability, define this negative $\mathrm{V}_{\mathrm{m}}$ of astrocytes. At rest intra-astrocytic concentration of $\mathrm{K}^{+}$is between 120 and $140 \mathrm{mM}$ and extracellular $\mathrm{K}^{+}$concentration is about $3 \mathrm{mM}$, which sets the equilibrium potential for $\mathrm{K}^{+}\left(\mathrm{E}_{\mathrm{K}}\right)$ at $-98 \mathrm{mV}$ (at $37^{\circ} \mathrm{C}$ ). Concentration of cytosolic $\mathrm{Na}^{+}$in astrocytes $(15-20 \mathrm{mM})$ is generally higher than in the majority of neurones $(8-10 \mathrm{mM})$. With $\mathrm{Na}^{+}$ concentration in the cerebrospinal fluid (CSF) around $145-155 \mathrm{mM}$, the corresponding $\mathrm{E}_{\mathrm{Na}}$ ranges between +55 and $+60 \mathrm{mV}[192,331]$. Concentration of ionised $\mathrm{Ca}^{2+}$ in the cytosol of astrocytes ranges between 50 and $150 \mathrm{nM}$, which for extracellular $\left[\mathrm{Ca}^{2+}\right]$ of $1.4 \mathrm{mM}$ sets the $\mathrm{E}_{\mathrm{Ca}}{ }^{2+}$ at +120 to $+140 \mathrm{mV}$. Cytosolic concentration of free $\mathrm{Mg}^{2+}$ in cultured astrocytes measured with a fluorescent probe Mag-Fura-2 is around $125 \mu \mathrm{M}$ [20]; the CSF $\mathrm{Mg}^{2+}$ has been determined at $\sim 0.9 \mathrm{mM}[384]$ giving $\mathrm{E}_{\mathrm{Mg}^{2+}}^{2+}+25 \mathrm{mV}$. 
High cytosolic $\mathrm{Cl}^{-}$concentration (30-50 mM) has been measured in cultured astrocytes and Bergmann glial cells in cerebellar slices [403]; this sets the $\mathrm{E}_{\mathrm{Cl}}{ }^{-}$around $-35 \mathrm{mV}$ (the $\left[\mathrm{Cl}^{-}\right]_{\mathrm{o}}$ is $\sim 120 \mathrm{mM}$ ). The concentration of protons in astroglial cytosol is $\sim 63 \mathrm{nM}$ (pH 7.2), which, assuming the extracellular $\mathrm{H}^{+}$concentration to be $\sim 40 \mathrm{nM}\left(\mathrm{pH}\right.$ 7.4) sets the $\mathrm{E}_{\mathrm{H}}{ }^{+}$at $\sim-12 \mathrm{mV}$. The cytosol of astrocytes is rich in $\mathrm{CO}_{2}(\sim 1.2 \mathrm{mM})$ and $\mathrm{HCO}_{3}{ }^{-}(\sim 17 \mathrm{mM})$.

The most characteristic electrophysiological signature of mature astrocytes is hyperpolarised resting potential $(\sim-80 \mathrm{mV})$ and low input resistance (5-20 M $\Omega$ ) indicative of high resting membrane permeability for $\mathrm{K}^{+}[242,243]$; the current to voltage relationship of astroglial cells is nearly linear $[2,73,161,168]$. Fluctuations of astroglial $V_{m}$ generally reflect changes in extracellular $\mathrm{K}^{+}$concentration $[11,81]$.

\subsection{Ion Channels}

\subsubsection{Potassium Channels}

Glial membrane permeability is dominated by $\mathrm{K}^{+}$channels, several types of which are expressed in astrocytes (Fig. 3.3). These channels have distinct voltage-dependence, which covers the whole range of physiological membrane potentials, thus ensuring the passive properties of astroglial plasma membrane. This prominent $\mathrm{K}^{+}$conductance of astrocytic plasmalemma defines the homeostatic capabilities of astrocytes [269], supporting movement of ions and providing electrical driving force for membrane transporters.

3.3.1.1 Inward Rectifier Potassium Channels, $\mathrm{K}_{\mathrm{ir}}$-Inward rectifying $\mathrm{K}^{+}$channels are so-called because they pass $\mathrm{K}^{+}$ions more easily into the cell (the inward direction) than out of the cell (the outward direction). The inward rectification occurs due to a voltagedependent intracellular block by $\mathrm{Mg}^{2+}$ and polyamines [225]. These two transmembrane domain channels belong to a gene super-family represented by 16 subtypes (KCNJ1$K C N J 18$ ), which are further divided into 7 families from $\mathrm{K}_{\mathrm{ir}} 1 . \mathrm{x}$ to $\mathrm{K}_{\mathrm{ir}} 7 . \mathrm{x}$ [139].

The main astroglial inward rectifying $\mathrm{K}^{+}$channels are represented by the $\mathrm{K}_{\mathrm{ir}} 4.1$ subtype (product of $K C N J 10$ gene). These channels are detected in many types of astroglia including protoplasmic and fibrous astrocytes, from all brain areas including hippocampus, neocortex, optic nerve, cerebellum, spinal cord and retina [58, 140, 169], with some regional variations; astroglia such as Müller glia and Bergmann glia express them as well. High $\mathrm{K}_{\mathrm{ir}} 4.1$ immunoreactivity was detected in hippocampal astrocytes, in astroglial cells in the cerebral cortex, in the deep cerebellar nuclei, in Bergmann glia and in Müller cells but not in astrocytes in white matter [309]. In the spinal cord, the expression of $\mathrm{K}_{\mathrm{ir}} 4.1$ channels is the highest in astrocytes from the ventral horn and the lowest in astrocytes from the apex of the dorsal horn [273]. The $\mathrm{K}_{\mathrm{ir}} 4.1$ channels are major contributors to the resting membrane potential of astroglial cells: functional inhibition or genetic deletion of $\mathrm{K}_{\mathrm{ir}}$ currents markedly increases input resistance (up to 20-fold) and depolarises astrocytes (by $20 \mathrm{mV}$ ) $[273,350]$.

The $\mathrm{K}_{\mathrm{ir}} 4.1$ may co-assemble with $\mathrm{K}_{\mathrm{ir}} 5.1$ channels forming heteromers, which were found in parenchymal and radial astrocytes, in the olfactory bulb, neocortex, cerebellum and retina $[50,138,159,251]$. The $\mathrm{K}_{\mathrm{ir}} 4.1 / \mathrm{K}_{\mathrm{ir}} 5.1$ heteromeric channels are concentrated in perisynaptic and perivascular processes of astrocytes and their processes close to the pia mater [138].

Adv Exp Med Biol. Author manuscript; available in PMC 2020 June 02. 
Some astrocytes in the hippocampus and cerebellum (including Bergmann glia) along with retinal Müller glia were found to express $\mathrm{K}_{\mathrm{ir}} 2.1, \mathrm{~K}_{\mathrm{ir}} 2.2$ and $\mathrm{K}_{\mathrm{ir}} 2.4$ channels [194, 214, 317, 380]. Astrocytes also express ATP-sensitive inward rectifying $\mathrm{K}^{+}$channels assembled from $\mathrm{K}_{\mathrm{ir}} 6 . \mathrm{x}$ subunit and SUR1/2; these channels open upon intracellular ATP depletion [96, 174, $365,395,431]$.

3.3.1.2 Voltage-Independent $\mathrm{K}^{+}$Channels-Another type of $\mathrm{K}^{+}$channels, which contributes to the resting membrane permeability of astrocytes is represented by members of the two-pore-domain potassium channels $\left(\mathrm{K}_{2 \mathrm{P}}\right)$ family encoded by $15 \mathrm{KCNK}$ genes [100]. Hippocampal astrocytes were found to express functional TREK1/K $2 \mathrm{P}^{2} .1(K C N K 2)$, TREK2/K $2 \mathrm{P} 10.1(K C N K 10)$ and TWIK1/K $2 \mathrm{P} 1.1(K C N K 1)$ channels [350, 432]. In cultured cortical astrocytes and astrocytes in hippocampal slices expression of TWIK-1/TREK-1 heterodimer (formed by disulphide bridge between cysteine-cysteine residuals of both subunits) has been demonstrated as the predominant channel type [156].

3.3.1.3 Voltage-Gated $\mathbf{K}^{+}$Channels, $\mathbf{K}_{\mathbf{v}}$-Astrocytes express delayed rectifying $\left(\mathrm{K}_{\mathrm{D}}\right)$ and transient $\left(\mathrm{K}_{\mathrm{A}}\right)$ voltage-gated $\mathrm{K}^{+}$channels. The delayed rectifying $\mathrm{K}^{+}$currents were identified in astrocytes throughout the CNS including the cortex, hippocampus, cerebellum and spinal cord [48]. At the molecular level, $\mathrm{K}_{\mathrm{v}} 1.5$ (KCNA5), $\mathrm{K}_{\mathrm{v}} 1.4\left(\right.$ KCNA4) and $\mathrm{K}_{\mathrm{v}} 11.1$ / ERG1 (KCNH2) have been identified in astrocytes from the hippocampus and spinal cord [97, 98, 334]. Astrocytes are also in possession of fast (rapidly activating and inactivating) A-type $\mathrm{K}^{+}$currents mediated by $\mathrm{K}_{\mathrm{v}} 1, \mathrm{~K}_{\mathrm{v}} 3$ and $\mathrm{K}_{\mathrm{v}} 4$ channels [32].

3.3.1.4 $\mathrm{Ca}^{2+}$-Dependent $\mathrm{K}^{+}$Channels, $\mathrm{K}_{\mathrm{Ca}}$-Several types of $\mathrm{Ca}^{2+}$-dependent $\mathrm{K}^{+}$ channels $\left(\mathrm{K}_{\mathrm{Ca}}\right)$ were found in astrocytes in vitro and in situ. At the mRNA level SK (small conductance $\mathrm{K}_{\mathrm{Ca}}$ 2.3/KCNN3) and IK (intermediate conductance $\mathrm{K}_{\mathrm{Ca}} 3.1 / \mathrm{KCNN} 4$ ) channels were detected in mouse cortical astrocytes in acutely isolated slices [222]. The $\mathrm{K}_{\mathrm{Ca}} 2.3$ immunoreactivity was found in astroglial processes in the rat supraoptic nucleus [17]. BK (big conductance) channels $\left(\mathrm{K}_{\mathrm{Ca}} 1.1 / \mathrm{KCNMA} 1\right)$ were identified in the perivascular astroglial endfeet in the hippocampus and cerebellum [315], whereas patch-clamp recordings obtained from endfeet revealed large-conductance (225 pS) BK-single channel currents [107].

\subsubsection{Sodium Channels}

3.3.2.1 Voltage-Gated Sodium Channels-Although being non-excitable cells, astrocytes express voltage-gated $\mathrm{Na}^{+}$channels $\left(\mathrm{Na}_{\mathrm{v}}\right)$, which were detected in vitro and in situ, albeit at low density [26, 28, 42, 371-374]. Cultured astrocytes from the optic nerve, hippocampus and spinal cord were found to express fast tetrodotoxin (TTX)-sensitive and slow TTX-resistant $\mathrm{Na}^{+}$currents [373, 374]. At the molecular level astrocytes mainly express $\mathrm{Na}_{\mathrm{v}} 1.5$ subunit which was identified both in vitro and in situ at mRNA and protein levels [40, 41, 286]; relatively low expression of $\mathrm{Na}_{\mathrm{v}} 1.2, \mathrm{Na}_{\mathrm{v}} 1.3$ [44] and $\mathrm{Na}_{\mathrm{v}} 1.6[321,345]$ were also detected; incidentally expression of $\mathrm{Na}_{\mathrm{v}} 1.6$ channels was found to increase in reactive astroglia [434].

Distribution of $\mathrm{Na}^{+}$channels in astrocytes from different brain regions as well as their physiological role remain poorly understood; hitherto $\mathrm{Na}^{+}$currents have not been recorded 
from astroglial cells in vivo. Possibly voltage-gated $\mathrm{Na}^{+}$channels contribute to $\mathrm{Na}^{+}$ signalling; it was also suggested that $\mathrm{Na}^{+}$influx mediated by these channels is needed for sustained activity of $\mathrm{Na}^{+} / \mathrm{K}^{+}$pump (see $[43,285,287]$ for further details).

3.3.2.2 $\left[\mathrm{Na}^{+}\right]_{0}-$ Regulated $\mathrm{Na}^{+}$Channels, $\mathrm{Na}_{\mathbf{x}}$-Specific type of $\mathrm{Na}^{+}$channels regulated by extracellular $\mathrm{Na}^{+}$concentration $\left(\left[\mathrm{Na}^{+}\right]_{\mathrm{o}}\right)$ are named $\mathrm{Na}_{\mathrm{x}}$ channels. They are expressed in astrocytes of the subfornical organ and organum vasculosum of the lamina terminalis (that are parts of circumventricular organs surrounding ventricles, structures where the blood-brain barrier is not as tight as in other parts of the brain) [267, 420]. These channels in vitro are opened following an increase in $\left[\mathrm{Na}^{+}\right]_{\mathrm{o}}$ to $150 \mathrm{mM}$. In vivo, in the presence of endothelin-3, which activates $\mathrm{ET}_{\mathrm{B}}$ receptors expressed in astroglia, the threshold for $\mathrm{Na}_{\mathrm{X}}$ channel activation is lowered to $140 \mathrm{mM}$ of $\left[\mathrm{Na}^{+}\right]_{\mathrm{o}}$ [141]. The $\mathrm{Na}_{\mathrm{x}}$ channels appear to operate as molecular sensors for $\left[\mathrm{Na}^{+}\right]$in the circulation (Fig. 3.4).

3.3.2.3 Epithelial Sodium Channel, ENaC-The epithelial $\mathrm{Na}^{+}$channels are nonvoltage gated, amiloride-sensitive $\mathrm{Na}^{+}$channels widely expressed in the CNS $[10,238,416]$. Immunohistochemistry found strong expression of ENaCs in astrocytes in circumventricular organs, white matter and pia mater [237]. These channels, together with $\mathrm{Na}_{\mathrm{x}}$ channels, may be involved in the regulation of systemic $\mathrm{Na}^{+}$homeostasis.

\subsubsection{Calcium Channels}

3.3.3.1 Voltage-Gated $\mathrm{Ca}^{2+}$ Channels-Early patch clamp recordings from astrocytes in culture revealed $\mathrm{Ba}^{2+}$ and $\mathrm{Ca}^{2+}$ currents sensitive to classic voltage-gated $\mathrm{Ca}^{2+}$ channel antagonists and enhanced by norepinephrine or by an increase in cytosolic $3^{\prime}, 5^{\prime}$-cyclic adenosine monophosphate, i.e. cAMP [27, 72, 228], the signalling by this second messenger complementing $\mathrm{Ca}^{2+}$ signalling in astrocytes [146]. Subsequently $\mathrm{Ca}_{\mathrm{v}} 1.2$ and $\mathrm{Ca}_{\mathrm{v}} 1.3$ channels were detected in the transcriptome of rodent cortical astrocytes [60, 430]. Several types of $\mathrm{Ca}^{2+}$ channel subunits (a1B or N-type, a 1C/D or L-type, a 1E or R-type and a 1G or T-type) were detected at mRNA and protein levels in astrocytes in culture [209]. Pituicytes analysed immunohistochemically in situ were found to possess $\mathrm{Ca}_{\mathrm{v}} 2.2$ (N-type) and $\mathrm{Ca}_{\mathrm{v}} 2.3$ (R-type) channels [418]. Evidence for functional activity of voltage-gated $\mathrm{Ca}^{2+}$ channels in situ is rather thin and indirect (see for example [215, 294]) and no evidence from the in vivo experiments exist at all. There are some indications for increased expression of voltage-gated $\mathrm{Ca}^{2+}$ channels in pathological or reactive astrocytes [419, 421].

3.3.3.2 Orai or $\mathrm{Ca}^{2+}$-Release Activated $\mathrm{Ca}^{2+}$ Channels-The $\mathrm{Ca}^{2+}$-release activated $\mathrm{Ca}^{2+}$ channels of Orai family (Orai1,2,3) represent one of the main molecular pathways of the store-operated $\mathrm{Ca}^{2+}$ entry (SOCE) in non-excitable cells [289]. Activation of these plasmalemmal channels is controlled by the stromal interacting molecules, STIM1 and STIM2, which act as $\mathrm{Ca}^{2+}$ sensors of the endoplasmic reticulum (ER) [368]. In cultured astrocytes Orai1 and STIM1 were detected at a protein level; over-expression of Orai1 increased the amplitude of SOCE, whereas siRNA knock out decreased SOCE [248]. Electrophysiological recordings of $\mathrm{I}_{\mathrm{CRAC}}$ performed on acutely dissociated Müller cells demonstrated sensitivity of the current to ORAI inhibitor Synta 66 [246]. 
3.3.3.3 $\mathrm{Ca}^{2+}$ Release Channels-Release of $\mathrm{Ca}^{2+}$ from the ER store in astrocytes is mainly mediated by Inositol 1,4,5-trisphosphate receptors $\left(\mathrm{InsP}_{3} \mathrm{R}\right)$, of which type 2 predominates $[133,144,354,356,414]$. Genetic deletion of $\operatorname{InsP}_{3} \mathrm{R}$ type $2\left(\mathrm{InsP}_{3} \mathrm{R} 2\right)$ has been shown to significantly reduce or even completely abolish $\mathrm{Ca}^{2+}$ signalling in astroglial cells from the hippocampus and cortex $[171,302]$. Other studies, however, reported $\left[\mathrm{Ca}^{2+}\right]_{\mathrm{i}}$ transients in $\mathrm{InsP}_{3} \mathrm{R}^{-/-}$mice astrocytes [130]. There is evidence for functional expression of InsP $\mathrm{P}_{3}$ Rs type 1 and 2 in astroglia [125, 327, 357].

Ryanodine receptors also have been identified in astrocytes [364, 414], although their functional role remains unclear. They supply $\mathrm{Ca}^{2+}$ necessary for $\mathrm{Ca}^{2+}$-dependent glutamate release from cortical astrocytes in culture. $\mathrm{Ca}^{2+}$-dependent glutamate release involves two classes of $\mathrm{ER} \mathrm{Ca}^{2+}$ stores in astrocytes [150]. There is some evidence for astroglial expression of the two-pore channels (TPC) that release $\mathrm{Ca}^{2+}$, and are activated by nicotinic acid adenine dinucleotide phosphate, i.e. NAADP [25, 301].

\subsubsection{Transient Receptor Potential (TRP) Channels}

Astrocytes express several types of cationic channels of TRP (transient receptor potential) family (Fig. 3.5). The 'ankyrin' channel TRPA1 was found in somata and processes of astrocytes in the brain stem in the rat trigeminal caudal nucleus using immunogold electron microscopy [211]. Functional expression of TRPA1 was also demonstrated in a subpopulation of hippocampal astrocytes [360, 362]. The TRPC ('canonical') channels were detected in freshly isolated and in primary cultured astrocytes, which were reported to express all subtypes of these channels from TRPC1 to TRPC6 [124, 244, 308]. These TRPC channels contribute to astroglial $\mathrm{Ca}^{2+}$ signalling induced by purinergic, glutamatergic and mechanical stimulation [231, 323, 324]. Astroglial TRPC channels represent a substantial pathway for store-operated $\mathrm{Ca}^{2+}$ entry in astroglia [412].

Rodent astrocytes from the brain and the spinal cord have been also reported to express TRPV1 channels [91, 151, 398]. Similarly TRPV4 channels have been identified in cortical and hippocampal astrocytes [22, 33, 57, 220]; these channels can be activated by hypoosmotic stress and by cell swelling $[33,57]$ in the absence of addition of membrane by exocytosis [283].

\subsubsection{Hyperpolarisation-Activated Cyclic Nucleotide-Gated (HCN) Channels}

The cationic $\left(\mathrm{Na}^{+} / \mathrm{K}^{+}\right) \mathrm{HCN}$ channels are found in both healthy and reactive astrocytes in situ [145, 337].

\subsubsection{Acid-Sensitive Ion Channels}

The acid-sensitive ion channels (ASIC1-3) were described in reactive astrocytes in the context of chronic epilepsy, and their activation was claimed to contribute to seizure generation [423].

\subsubsection{Anion Channels}

Astrocytes express the following anion channels: (i) cystic fibrosis transmembrane conductance regulator or CFTR channels, (ii) voltage-dependent anion-selective channels or 
VDAC, (iii) $\mathrm{Ca}^{2+}$-dependent $\mathrm{Cl}^{-}$channels (iv) volume-regulated anion channels or VRAC and (v) ClC-1, -2 and -3 channels [186, 291, 410, 429]. The ClC-2 channels are concentrated in astroglial processes enwrapping GABAergic synapses [363], which may indicate their role for regulation of intra-cleft $\mathrm{Cl}^{-}$concentration and hence of GABAergic transmission. Astrocytes also express an anion channel of Bestrophin (Best) family; these channels were suggested to contribute to the $\mathrm{Ca}^{2+}$-dependent secretion of glutamate and GABA [290, 422].

\subsubsection{Aquaporins}

Three types of aquaporins, the AQP1, AQP4 and AQP9 were identified in astroglia although AQP4 is the most abundant [21, 256, 342]; the plasma membrane contains mainly the AQP4e isoform [219, 313]. Astroglial AQP4 channels are concentrated in the perivascular and subpial endfeet [256]. Genetic deletion of AQP4 affects olfaction [224] and hearing; it results in a decrease in astroglial water permeability [370], deficient $\mathrm{K}^{+}$buffering, compromised volume regulation [39, 219], and deficits in synaptic plasticity [346, 367], and memory [367, 427].

\subsubsection{Connexons}

Connexons form gap junctional channels that integrate astrocytes into functional syncytia, subject to regulation by G-protein coupled receptors [392]. Astrocyte-astrocyte homocellular gap junctions are composed of Cx26, Cx30 and Cx43 [117, 198, 258], of which Cx43 is the most abundant [257]. The Cx43 is expressed in astroglial cells in all CNS regions, whereas Cx30 is mostly expressed in the thalamus and leptomeninges [257, 369]. The Cx26 subtype has been detected in astrocytes in the hypothalamus, reticular thalamic and subthalamic nuclei [259]. Astrocyte-oligodendrocyte heterocellular gap junctions are composed of heterotypic channels represented, in vitro, by four complexes: $\mathrm{Cx} 47 / \mathrm{Cx} 43, \mathrm{Cx} 47 / \mathrm{Cx} 30$, Cx32/Cx30 or Cx32/Cx26 [230], although in situ Cx32/Cx30 and Cx47/Cx43 complexes appear to predominate $[8,277]$. There are some sporadic reports of astrocyte-neuronal heterocellular contacts $[9,255,279]$, and these contacts are arguably limited to developing brain.

Unpaired connexons, or hemichannels, have been identified in astrocytes in vitro and in vivo; all three major connexons ( $\mathrm{Cx} 26, \mathrm{Cx} 30$ and $\mathrm{Cx} 43$ ) expressed in astrocytes can act as hemichannels [119]. The hemichannels are non-operational in healthy astrocytes, but can be activated by low external calcium concentration, by substantial depolarisation, by some specific intracellular $\mathrm{Ca}^{2+}$ signals, or by exposure to pro-inflammatory agents [274, 275]. The hemichannels can contribute to secretion of neurotransmitters and neuromodulators [293] and are subject to regulation via transmitters and G-protein coupled receptors.

\subsubsection{Pannexons}

Transcripts for pannexin 1 (Panx1) were identified in astroglia in vitro and in situ $[153,320]$, with Panx1 currents characterised in cultured cortical astrocytes [157]. Astroglial pannexons are activated by voltage and by activation of $\mathrm{P} 2 \mathrm{X}_{7}$ receptors; they are inhibited by broadspectrum gap junction antagonists carbenoxolone and mefloquine, and they are permeable to 
fluorescent tracer YoPro [157]. Panx1 containing pannexons have been considered as a transmembrane conduit for ATP [78].

\subsection{Receptors}

Conceptually, astrocytes have been shown to express virtually any type of receptor found in the CNS. At the same time the pattern of receptors expressed by astrocytes in situ and in vivo is restrictive and is regulated by the local neurochemical environment [183, 410, 411].

\subsubsection{Purinoceptors}

3.4.1.1 Adenosine Receptors-All four types of adenosine receptors $\left(A_{1}, A_{2 A}, A_{2 B}\right.$ and $\mathrm{A}_{3}$ ) were found in astrocytes in the in vitro and in situ preparations [84]. These receptors are linked to intracellular second messenger systems including $\mathrm{InsP}_{3}, \mathrm{Ca}^{2+}$ and cAMP cascades (Fig. 3.6). Activation of $\mathrm{A}_{1}$ receptors triggered intracellular $\mathrm{Ca}^{2+}$ release as well as $\mathrm{Ca}^{2+}$ entry and potentiated histamine-induced $\mathrm{Ca}^{2+}$ mobilisation [297, 310]. Similarly, $\mathrm{A}_{2 \mathrm{~A}}$ receptors were responsible for $\mathrm{Ca}^{2+}$ signalling in astrocytes from the olfactory bulb [90], whereas $\mathrm{A}_{2 \mathrm{~B}}$ receptors triggered $\mathrm{Ca}^{2+}$ signals in cortical astroglia [306]. The $\mathrm{A}_{3}$ receptors mediated adenosine- and guanosine-evoked $\left[\mathrm{Ca}^{2+}\right]_{\mathrm{i}}$ transients in cultured mouse astrocytes [68].

3.4.1.2 P2X Purinoceptors-Transcripts for all seven types of ionotropic purinoceptors ( $\mathrm{P} 2 \mathrm{X}_{1}-\mathrm{P} 2 \mathrm{X}_{7}$, Fig. 3.6) have been detected in astrocytes in vitro and in tissue extracts [89, $109,113,162]$. At the protein level, $\mathrm{P} 2 \mathrm{X}_{2,3,4}$ receptors were found in astrocytes from the nucleus accumbens [109]. $\mathrm{P} 2 \mathrm{X}_{1}$ and $\mathrm{P} 2 \mathrm{X}_{2}$ receptors were found in astroglial cells in the cerebellum [173, 221]; $\mathrm{P} 2 \mathrm{X}_{4}$ receptors were identified in astrocytes from the brainstem [18] and in Müller glia [142], whereas hippocampal astrocytes were immunoreactive for $\mathrm{P}_{2} \mathrm{X}_{1-4}$, $\mathrm{P}^{2} \mathrm{X}_{6}$ and $\mathrm{P} 2 \mathrm{X}_{7}$ receptors [197].

Ion currents mediated by heteromeric $\mathrm{P} 2 \mathrm{X}_{1 / 5}$ receptors were characterised in cortical mouse astrocytes [204]). These receptors contribute to 'glial synaptic currents' monitored in astrocytes in response to stimulation of neuronal afferents [200, 203]; in addition P2 $\mathrm{X}_{1 / 5}$ receptors produced spontaneous 'miniature' post-synaptic currents in astrocytes in cortical slices [203]. Astroglial $\mathrm{P} 2 \mathrm{X}_{1 / 5}$ receptors have intermediate $\mathrm{Ca}^{2+}$ permeability $\left(\mathrm{P}_{\mathrm{Ca}}{ }^{2+} /\right.$ $\mathrm{P}_{\text {monovalent }} \sim 2.2$ ), and their activation by endogenous agonosts, or by synaptically released ATP, triggers transient cytoplasmic $\mathrm{Ca}^{2+}$ signals [281].

Astrocytes have been reported to express $\mathrm{P} 2 \mathrm{X}_{7}$ receptors both in healthy and pathological contexts $[111,158]$. In astrocytes in vitro $\mathrm{P} 2 \mathrm{X}_{7}$ receptors were detected at mRNA and protein levels [89, 93, 113, 154, 164, 260, 282, 417]. Astroglial expression of $\mathrm{P}_{2} \mathrm{X}_{7}$ receptors, as a rule, increases after brain injury of various aetiology [109, 110, 260]. In astrocytes in culture both $\mathrm{P} 2 \mathrm{X}_{7}$-mediated $\mathrm{Ca}^{2+}$ signals and membrane currents have been detected $[93,113,266,268,335]$. Astroglial $\mathrm{P} 2 \mathrm{X}_{7}$ currents were also characterised in rat and mouse cortical slices. Activation of $\mathrm{P} 2 \mathrm{X}_{7}$ receptors in cultured astrocytes may be associated with release of glutamate, GABA, ATP [24, 93, 94, 382]. The P2X $\mathrm{X}_{7}$-mediated release of glutamate was also identified in astrocytes in hippocampal slices [106].

Adv Exp Med Biol. Author manuscript; available in PMC 2020 June 02. 
3.4.1.3 P2Y Receptors-Astrocytes in cortex express transcripts for $\mathrm{P} 2 \mathrm{Y}_{1,2,4,6,12,13}$ and UDP-glucose $\mathrm{P}_{2} \mathrm{Y}_{14}$ receptor $[1,36,89,113]$, whereas spinal cord astrocytes predominantly express mRNA for $\mathrm{P}_{2} \mathrm{Y}_{1,2}$ receptors [104]. Stimulation of astroglial $\mathrm{P} 2 \mathrm{Y}$ receptors triggers $\mathrm{Ca}^{2+}$ signals originating from $\mathrm{InsP}_{3}$-induced $\mathrm{ER} \mathrm{Ca}^{2+}$ release $[38,56,160,163,175,298$, 299, 407].

\subsubsection{Glutamate Receptors}

3.4.2.1 Ionotropic Glutamate Receptors-Astrocytes from different regions of the brain express a-amino-3-hydroxy-5-methyl-isoxazole propionate (AMPA) receptors (Fig. 3.7), which have been characterised at expression and functional levels. All main subunits of AMPA receptors (GluA1-GluA4) have been detected in astroglial cells. In the hippocampus, AMPA receptors are assembled predominantly from GluA2 and GluA4 subunits, which are reflected by a linear I-V relation and low $\mathrm{Ca}^{2+}$ permeability [351]. In cortical astrocytes these receptors are composed of GluA1 and GluA4 subunits [75]. In Bergmann glial cells AMPA receptors do not contain GluA2 subunit, and accordingly they have a doublerectifying I-V relationship and low $\left(\mathrm{P}_{\mathrm{Ca}}{ }^{2+} / \mathrm{P}_{\text {monovalent }} \sim 1\right) \mathrm{Ca}^{2+}$ permeability $[115,253]$. Conditional deletion of AMPA receptors, composed of GluA1 and GluA4 subunits, from Bergmann glia led to a retraction of glial perisynaptic processes and deficient fine motor coordination [338].

Astrocytes also possess functional N-methyl D-aspartate (NMDA) receptors. The transcriptome of human astroglia contains all 7 NMDA receptors subunits (GluN1, GluN2/A-D and GluN3A,B-[210]). In acute slices the NMDA-mediated currents and $\mathrm{Ca}^{2+}$ signals were found in astrocytes in the neocortex [202, 272, 348], in the spinal cord [437], and in some cells in the hippocampus [311, 376]. Astroglial NMDA receptors heterotetramers assembled from obligatory two GluN1 and additional subunits of each GluN2 C or D and GluN3; this composition underlies a weak $\mathrm{Mg}^{2+}$ block (which develops at $\sim-120 \mathrm{mV})$ and relatively low $\mathrm{Ca}^{2+}$ permeability $\left(\mathrm{P}_{\mathrm{Ca}} / \mathrm{P}_{\text {monovalent }} \sim 3\right)$, as well as sensitivity to memantine and GluN2C/D subunit-selective antagonist UBP141 [95, 203, 280, 281].

3.4.2.2 Metabotropic Glutamate Receptors-The most abundant type of astroglial metabotropic receptors in mature CNS is represented by mGluR3, which inhibits adenylyl cyclase [385]. In younger animals astrocytes express mGluR1/5 receptors linked to $\mathrm{Ca}^{2+}$ signals and $\left[\mathrm{Ca}^{2+}\right]_{\mathrm{i}}$ oscillations $[76,191,208,312]$.

\subsubsection{GABA Receptors}

Astrocytes express both ionotropic $\mathrm{GABA}_{\mathrm{A}}$ and metabotropic $\mathrm{GABA}_{\mathrm{B}}$ receptors. The $\mathrm{GABA}_{\mathrm{A}}$ receptors mediated $\mathrm{Cl}^{-}$currents have been characterised in astroglial cells in culture and in situ in the hippocampus, cerebellum, retina, hypothalamus, supraoptic nucleus and spinal cord $[74,179,180,182,229,252]$. The subunit composition of astroglial $\mathrm{GABA}_{\mathrm{A}}$ receptors is not certain; $a 1$ and $\beta 1$ subunits were detected in hippocampal astrocytes [112] and $\alpha 2$ and $\gamma 1$ in Bergmann glia [326]. Metabotropic $\mathrm{GABA}_{\mathrm{B}}$ receptors evoke astroglial $\mathrm{Ca}^{2+}$ signalling by triggering $\mathrm{Ca}^{2+}$ release from the ER [264]. 


\subsubsection{Glycine Receptors}

Glycine receptors mediate $\mathrm{Cl}^{-}$currents in astrocytes in the spinal cord slices [295]. Singlecell RT-PCR performed on these astrocytes revealed expression of $a 1$ and (in $~ 50 \%$ of cells) $\beta$-subunits of the receptor [188].

\subsection{Acetylcholine Receptors}

The ionotropic nicotinic acetylcholine receptors (nAChRs) have been characterised in astrocytes in culture and in acute slices. Activation of these receptors mediates $\mathrm{Ca}^{2+}$ influx and triggers $\mathrm{Ca}^{2+}$-induced $\mathrm{Ca}^{2+}$ release $[271,353,389]$. Analysis of mRNA expression in rodent cortical astrocytes found $\alpha 4, \alpha 7$ and $\beta 2$ subunits, whereas in human astroglial cells from the hippocampus and entorhinal cortex $\alpha 3, a 7$ and $\beta 4$ subunits were identified by immunocytochemistry [121, 390].

The metabotropic $\mathrm{M}_{1}$ and $\mathrm{M}_{2} \mathrm{AChRs}$ mediate $\mathrm{Ca}^{2+}$ signalling in astrocytes from hippocampal slices [15].

\subsection{Receptors for Monoamines}

Astroglial cells express receptors for major monoamines including adrenoceptors, and receptors for serotonin, dopamine and histamine. Both $\alpha$ - and $\beta$-adrenoceptors have been identified and characterised in astrocytes in culture, in slices, and in vivo at transcript, protein and functional levels $[14,135]$. The $a_{1}$-adrenoceptors are coupled to phospholipase$\mathrm{C}$ (PLC) and InsP $\mathrm{P}_{3}$ signalling and hence to $\mathrm{Ca}^{2+}$ release from the ER [55, 193, 352]. Immunoreactivity for $\mathrm{a}_{2}$-adrenoceptors was found in astrocytic processes in the brain tissue $[14,239]$; activation of $a_{2^{-}}$-adrenoceptor also triggers $\mathrm{Ca}^{2+}$ signalling [265, 339]. $\beta_{1^{-}}, \beta_{2^{-}}$ and $\beta_{3}$-adrenoceptors were characterised in astrocytes in vitro and in vivo $[62,232,352]$. $\beta_{1^{-}}$ adrenoceptors contribute to regulation of glycogen synthesis, while $\beta_{2}$-adrenoceptors coupled to adenylyl cyclase through $\mathrm{G}_{\mathrm{s}}$ proteins together with possibly $\beta_{3}$-adrenoceptors regulate glucose uptake by modulating GLUT1 plasmalemmal glucose transporter [92, 155].

Astrocytes express $5-\mathrm{HT}_{1 \mathrm{~A}}, 5-\mathrm{HT}_{2 \mathrm{~A}}, 5-\mathrm{HT}_{2 \mathrm{~B}}$ and $5-\mathrm{HT}_{5 \mathrm{~A}}$ metabotropic serotonin receptors, $[19,61,341] .5-\mathrm{HT}_{2}$ receptors activate $\mathrm{PLC} / \mathrm{InsP}_{3} / \mathrm{Ca}^{2+}$ signalling cascade [341]. 5- $\mathrm{HT}_{2 \mathrm{~B}}$ receptor seems rather abundant in astrocytes [196] with its expression as twice as large as in neurones [428]. Serotonin-specific reuptake inhibitors (major anti-depressant agents such as fluoxetine or sertraline) directly activate astroglial 5- $\mathrm{HT}_{2 \mathrm{~B}}$ receptors $[136,428]$ with subsequent $\mathrm{Ca}^{2+}$ signalling [347] or phosphorylation of extracellular regulated kinases 1/2 (ERK1/2) or up-regulation of $\mathrm{Ca}^{2+}$-dependent phospholipase A2 (cPLA2) [136, 428].

Dopamine $\mathrm{D}_{1}, \mathrm{D}_{2}, \mathrm{D}_{4}$ and $\mathrm{D}_{5}$ receptors have been detected in astroglia at transcript and protein levels [245] with higher expression of $\mathrm{D}_{1}$ [425] or $\mathrm{D}_{2}$ receptors [23]; astrocytes from the striatum were claimed to express $\mathrm{D}_{5}$ receptors [52]. Strong presence of $\mathrm{D}_{2}$ receptors was found in astroglial processes enwrapping cortical interneurones [184]. Activation of $\mathrm{D}_{1}$ and $\mathrm{D}_{2}$ receptors in astrocytes triggers $\mathrm{Ca}^{2+}$ signalling originating from the $\mathrm{InsP}_{3}$-induced ER $\mathrm{Ca}^{2+}$ release $[184,322]$. 
Astroglia express $\mathrm{H}_{1}, \mathrm{H}_{2}$ and $\mathrm{H}_{3}$ histamine receptors [166]. Astrocytic $\mathrm{H}_{1}$ receptors are coupled to $\mathrm{PLC} / \mathrm{InsP}_{3} / \mathrm{Ca}^{2+}$ signalling cascade $[193,355]$, regulation of glucose metabolism [16] and up-regulation of EAAT2/GLT-1 plasmalemmal glutamate transporter [105]; the latter also modulated by cytosolic $\mathrm{Ca}^{2+}[377]$.

\subsection{Bradykinin Receptors}

The $\mathrm{B}_{2}$ bradykinin receptors were identified in cultured astrocytes [71]; stimulation of these receptors induces $\mathrm{InsP}_{3}$ production, $\mathrm{Ca}^{2+}$ signalling and glutamate release [292, 378].

\subsection{Cannabinoid Receptors}

Astrocytes express cannabinoid $\mathrm{CB}_{1}$ receptors, which are involved in regulation of cellular metabolism [46, 340]. The $\mathrm{CB}_{1}$-mediated astroglial $\mathrm{Ca}^{2+}$ signalling was detected in response to neuronal release of endocannabinoids [261]. Activation of $\mathrm{CB}_{1}$ receptors in astroglia was also claimed to regulate neuronal synaptic plasticity [262].

\subsection{Neuropeptide Receptors}

$\mathrm{V}_{1}$ vasopressin receptors induced $\mathrm{Ca}^{2+}$ signalling was found in cultured astrocytes and in pituicytes $[129,167]$. Oxytocin receptors linked to $\mathrm{PLC}_{\mathrm{InsP}} / \mathrm{ER} \mathrm{Ca}^{2+}$ release were identified in rat embryonic cultured hippocampal astrocytes [87] and in hypothalamic astrocytes [199].

$\mathrm{ET}_{\mathrm{A}}$ and $\mathrm{ET}_{\mathrm{B}}$ endothelin receptors were initially described in cultured astrocytes [147, 405]. Stimulation of $\mathrm{ET}_{\mathrm{A} / \mathrm{B}}$ receptors resulted in astroglial $\mathrm{Ca}^{2+}$ signalling [47, 233]. In mouse cerebellar Bergmann glial cells, endothelin evoked $\left[\mathrm{Ca}^{2+}\right]_{\mathrm{i}}$ transients sensitive to the selective $\mathrm{ET}_{\mathrm{B}}$ receptor antagonist $\mathrm{BQ}-788$ [399]. Activation of $\mathrm{ET}_{\mathrm{A} / \mathrm{B}}$ receptors also suppresses astroglial gap junctions due to dephosphorylation of Cx43 $[47,116]$.

Receptors to atrial natriuretic peptide (NPR) were first identified in cultured mouse astrocytes [393]. Subsequently NPR-A [383], NPR-B [383, 438] and NPR-C [366, 383] receptors have been characterised. NPR-A and NPR-B increase intracellular cyclic guanosine monophosphate (cGMP), while NPR-C acts as a 'clearance receptor' that removes peptides from the extracellular space [314].

Astrocytes have been found to express $\delta$ and $\kappa$-opioid receptors [101, 102]; $\kappa$-opioid receptors induced $\mathrm{Ca}^{2+}$ signals sensitive to nifedipine [103], while $\delta$-receptors, are linked to $\mathrm{ER} \mathrm{Ca}^{2+}$ release [396]. Opioid receptors were claimed to regulate expression of plasmalemmal glutamate transporters [218], and astroglial growth [379].

\subsection{Receptors for Leptin and Insulin}

Expression of leptin receptors was detected in astrocytes in the subcommissural organ [79], in the nucleus tractus solitarius [80] and in the hypothalamus [149].

Insulin receptors have been characterised in astrocytes in vitro [131, 435]. Genetic deletion of insulin receptors from astrocytes affected brain glucose sensing, and reduced astroglial 
coverage of hypothalamic neurones [114]. Insulin may also act via the insulin-like growth factor 1 (IGF-1) receptor. Activation of insulin and IGF-1 receptors upregulates levels of glycogen in cultured rodent astrocytes [250].

\subsection{Platelet-Activating Factor Receptor}

Receptors for platelet-activating factor (1-O-alkyl-2-acetyl-sn-glycero-3-phosphocholine) were detected in astrocytes in vitro [53]. Activation of platelet-activating factor receptors stimulated production of $\mathrm{InsP}_{3}[254,304]$, induced secretion of nerve growth factor [54] and prostaglandin $\mathrm{E}_{2}$ [391].

\subsection{Protease-Activated Receptors (PAR)}

Thrombin-activated PAR-1 and trypsin-activated PAR-2 receptors were found in cultured rat newborn astrocytes; activation of these receptors induced $\mathrm{ER} \mathrm{Ca}^{2+}$ release [400, 401]. Astroglial PAR receptors are coupled to several signalling pathways, including stabilisation of hypoxia inducible factor-1a through ERK, JNK and PI3K/Akt cascades [436]. Activation of PAR-1 receptors (for example, by the selective peptide agonist TFLLR) is often used for selective stimulation of astroglia in situ [201,359], although there are reports of neuronal $\mathrm{Ca}^{2+}$ signals triggered by the TFLLR-sensitive receptors [127].

\subsection{Astroglial Membrane Transporters}

\subsubsection{ATP-Dependent Transporters}

The most prominent and functionally important astroglial membrane P-type ATPase is represented by the $\mathrm{Na}^{+}-\mathrm{K}^{+}$ATPase (NKA), that counter-transports $\mathrm{Na}^{+}$and $\mathrm{K}^{+}$with a stoichiometry of $3 \mathrm{Na}^{+}$(expelled from the cell): $2 \mathrm{~K}^{+}$(imported into the cell). This defines electrogeneity of NKA. Astrocytes exclusively express a 2 catalytic subunit [137, 165], which defines its peculiar properties. In contrast to neurones (which express a 1 subunit) astroglial NKA is activated by physiological rises in $\left[\mathrm{K}^{+}\right]_{0}$, while neuronal NKA is activated by an increase in $\left[\mathrm{Na}^{+}\right]_{\mathrm{i}}[134,207,329]$. This stipulates the leading role of astroglial NKA in $\mathrm{K}^{+}$buffering. Astrocytes also express plasmalemmal $\mathrm{Ca}^{2+}$-ATPases (PMCAs) and Sarco(Endo)Plasmic Reticulum $\mathrm{Ca}^{2+}$ ATP-ase (SERCA) both being responsible for $\mathrm{Ca}^{2+}$ homeostasis [410]. Astroglial plasma membrane and astroglial secretory vesicles possess the vacuolar V-type $\mathrm{H}^{+}$ATPase [288, 305].

\subsubsection{Secondary Plasmalemmal Transporters of Solute Carrier (SLC) Family}

3.13.2.1 Glutamate Transporters-Astrocytes represent the main sink for glutamate in the CNS [82, 410, 433]. Astrocytes express two types of plasmalemmal glutamate transporters: the excitatory amino acid transporters 1 and 2 (EAAT1/SLC1A6 and EAAT2/ SLC1A2), which in rodent experiments are also referred to as GLAST1 (glutamate-aspartate transporter 1 [381]) and GLT-1 (glutamate transporter 1 [307]). The EAAT1 is predominantly expressed in the cerebellum [212], in the retina [319] and in circumventricular organs [37]; in all other parts of the brain the EAAT2 is the major type. The average density of EAAT1 is $\sim 4700 / \mu \mathrm{m}^{2}$ in Bergmann glia, and $\sim 2300 / \mu \mathrm{m}^{2}$ in the CA1 region of the hippocampus; the density of EAAT2 is $\sim 8500 / \mu \mathrm{m}^{2}$ in the hippocampus and 
$\sim 740 / \mu \mathrm{m}^{2}$ in the cerebellum [212]. Both transporters are concentrated in perisynaptic astroglial processes [66].

The stoichiometry of EAAT1 and EAAT2 is $3 \mathrm{Na}^{+}, 1 \mathrm{H}^{+}, 1$ glutamate ${ }^{-}$in (glutamate is an anion at physiological conditions): $1 \mathrm{~K}^{+}$out $[278,426]$. The equilibrium potential $\mathrm{E}_{\mathrm{EAAT}}$ is the function of ions and glutamate concentration; the extracellular glutamate concentration varies between $25 \mathrm{nM}$ at rest and $1 \mathrm{mM}$ during synaptic transmission. The intracellular concentration of glutamate in astrocytes is $\sim 0.3 \mathrm{mM}$ due to high activity of glutamine synthetase $[49,132]$. At the rest the $\mathrm{E}_{\mathrm{EAAT}}$ is about $+9 \mathrm{mV}$, whereas at $1 \mathrm{mM}$ of glutamate in the cleft the transporter reverses at $+145 \mathrm{mV}$ [410]. The transporter is electrogenic and generates transmembrane current carried mainly by $\mathrm{Na}^{+}$ions [190, 404]. This $\mathrm{Na}^{+}$influx may elevate $\left[\mathrm{Na}^{+}\right]_{\mathrm{i}}$ by $10-30 \mathrm{mM}[331]$.

Astrocytes also express the cystine/glutamate antiporter $\mathrm{Sxc}^{-}$, which localises extrasynaptically $[7,70,176]$. This transporter is important for accumulation of cystine needed for production of glutathione.

3.13.2.2 Glutamine Transporters-The obligatory glutamate (and in proxy GABA) precursor glutamine is exported from astrocytes by SNAT3/SLC38A3 and SNAT5/SLC38A5 plasmalemmal glutamine transports, which are coupled with co-transport of $1 \mathrm{Na}^{+}$and counter-transport of $1 \mathrm{H}^{+}$[343]. Astroglial $\mathrm{Na}^{+}$signals stimulate glutamine efflux [397].

3.13.2.3 GABA Transporters-Astrocytes predominantly express GAT3 GABA plasmalemmal transporter with much lower expression of GAT1. The GAT3 are concentrated in astroglial processes [241, 325]. In the cerebellum GAT3 is localised in the perisynaptic processes of Bergmann glia, enwrapping inhibitory synapses [241]. In thalamic astrocytes GAT1 is concentrated in perisynaptic membranes, whereas GAT3 is localised more distantly being thus responsible for extrasynaptic GABA transport [31]. The stoichiometry of both transporters is $1 \mathrm{GABA}: 2 \mathrm{Na}^{+}: 1 \mathrm{Cl}^{-}$, being thus electrogenic [177, $223,318]$. The reversal potential $\mathrm{E}_{\mathrm{GAT}}$ lies around $-50 \mathrm{mV}$; hence, relatively small depolarisation and/or an increase in $\left[\mathrm{Na}^{+}\right]_{\mathrm{i}}$ favour the reverse mode operation of these transporters [402].

3.13.2.4 Glycine Transporters-Astroglial cells express GlyT1/SLC6A9 glycine plasmalemmal transporters [424]. Their stoichiometry is 1 glycine: $2 \mathrm{Na}^{+}: 1 \mathrm{Cl}^{-}$[333]. The transporter can reverse at physiological membrane potentials [358]. This transportermediated glycine release was shown to be stimulated by dopamine [152].

3.13.2.5 Adenosine Transporters-Astrocytes express both equilibrative (i.e. controlled by adenosine transmembrane gradient, [187]) plasmalemmal transporters ENT-1/ SLC29A1, ENT-2/SLC29A2, ENT-3/SLC29A3 and ENT-4/SLC29A4, and $\mathrm{Na}^{+}$-dependent concentrative nucleoside plasmalemmal transporters CNT2/SLC28A2 and CNT3/SLC28A3, which co-transport adenosine together with $1 \mathrm{Na}^{+}[217,300]$.

3.13.2.6 Transporters for Monoamines-It seems that the main astroglial monoamine plasmalemmal transporter is represented by norepinephrine transporter NET/ 
SLC6A2 that couples monoamine transport with $2 \mathrm{Na}^{+}$and $1 \mathrm{Cl}^{-}$, this transporter has higher affinity for dopamine than norepinephrine [349, 387].

3.13.2.7 D-Serine Transporters-Transmembrane transport of D-serine in astrocytes is mediated by a neutral amino acid transporter subtype ASCT2 (SLC1A5), which is an alanine-, serine-, cysteine-preferring neutral amino acid plasmalemmal transporter [234]. The ASCT2 is a $\mathrm{Na}^{+}$-dependent with $\mathrm{Na}^{+}$to amino acid stoichiometry of 1:1 [235].

3.13.2.8 Sodium-Calcium Exchangers-All three known plasmalemmal sodiumcalcium exchangers, NCX1/SLC8A1, NCX2/SLC8A2 and NCX3/SLC8A3, are expressed in astroglia [287]. The NCXs are mainly concentrated in astroglial perisynaptic processes, and co-localise with glutamate transporters and possibly with glutamate ionotropic receptors [45, 240]. The stoichiometry of astroglial NCX is $3 \mathrm{Na}^{+}: 1 \mathrm{Ca}^{2+}$, and hence the equilibrium $\mathrm{E}_{\mathrm{NCX}}$ lies at $\sim-85$ to $-90 \mathrm{mV}$ at rest making it prone for fluctuating between forward and reverse modes [415]. Membrane depolarisation and increase in intracellular $\mathrm{Na}^{+}$ concentration favour NCX to operate in the reverse mode, whereas increase in $\left[\mathrm{Ca}^{2+}\right]_{\mathrm{i}}$ promotes the forward mode. Operation of astroglial NCX was shown in vitro $[120,388]$ and in situ [189].

\subsubsection{Sodium-Proton Exchanger, or NHE-Astrocytes express NHE1/SLC9A1} $\mathrm{Na}^{+}-\mathrm{H}^{+}$exchanger $[69,85]$ with electroneutral stoichiometry $1 \mathrm{Na}^{+}$(in): $1 \mathrm{H}^{+}$(out) [276]. The NHE1 is primarily responsible for efflux of protons generated by cytoplasmic metabolism and accumulated by astrocytes through glutamate uptake (each glutamate brings a single $\mathrm{H}^{+}$ion) and $\mathrm{Ca}^{2+}$ extrusion (PMCA exchanges $2 \mathrm{H}^{+}$for each $\mathrm{Ca}^{2+}$ ion expelled).

3.13.2.10 Sodium-Bicarbonate Co-transporter, NBC-The sodium-bicarbonate transporter NBCe1/SLC4A4 has been identified in astrocytes in culture [270] and in hippocampal slices [122]. The NBC stoichiometry is $1 \mathrm{Na}^{+}: 2 \mathrm{HCO}_{3}{ }^{-}$or $1 \mathrm{Na}^{+}: 3 \mathrm{HCO}_{3}{ }^{-}$ [263], and this transporter can operate in both forward and reverse modes [394].

\subsubsection{Sodium-Potassium-Chloride Co-transporter, NKCC1- $\mathrm{The}^{\mathrm{N}} \mathrm{a}^{+}-\mathrm{K}^{+}$} Cl-co-transporter NKCC1/SLC12A2 has been detected in Bergmann glia [170], in astrocytes from the optic nerve [227] and spinal cord [316]. It has an electroneutral stoichiometry of 1 $\mathrm{Na}^{+:} 1 \mathrm{~K}^{+}: 2 \mathrm{Cl}^{-}$[226]. Experiments in situ in hippocampal slices questioned the functional role of NKCC1 in protoplasmic astrocytes in the healthy brain [207].

3.13.2.12 Glucose Transporters-Astrocytes express the glucose transporter GLUT1/ SLC2A1 [6], which is predominantly localised in endfeet and perisynaptic processes. Immunostaining revealed the presence of this transporter in grey matter astroglia [249]. It also contains GLUT4, a transporter sensitive to insulin in skeletal muscle, however the flux of glucose in astrocytes is not upregulated by insulin [250].

3.13.2.13 Monocarboxylate Transporters, MCT-Monocarboxylate transporters 1 and 4 (MCT1/SLC16A1, MCT4/SLC16A3) provide for export of lactate from astroglial cells [126]. They may, however, mediate both export or import of lactate depending on concentration gradients for monocarboxylate and $\mathrm{H}^{+}[126]$. 


\subsection{Ionic Signalling in Astroglia}

\subsubsection{Calcium Signalling}

Discovery of astroglial $\mathrm{Ca}^{2+}$ signals and propagating $\mathrm{Ca}^{2+}$ waves $[63,76,83,99,108,185$, 236] led to the formulation of the concept of astrocytic ionic signalling as a basis for their excitability [411]. Astroglial $\mathrm{Ca}^{2+}$ signalling depends on both intracellular and extracellular sources (Fig. 3.8) [414]. Somatic $\mathrm{Ca}^{2+}$ signals almost entirely depend on $\mathrm{Ca}^{2+}$ release from the ER mediated by $\mathrm{InsP}_{3}$ receptor type 2; deletion of this channel often substantially reduced or even eliminated somatic $\left[\mathrm{Ca}^{2+}\right]_{\mathrm{i}}$ transients $[4,171,302,303]$. At the same time, $\mathrm{Ca}^{2+}$ signals in astroglial processes remain even in the $\mathrm{InsP}_{3} \mathrm{R}^{-/-}$mice $[130,172,375]$. These signals were mediated by plasmalemmal $\mathrm{Ca}^{2+}$ influx [336]. This $\mathrm{Ca}^{2+}$ influx may reflect upon $\mathrm{Ca}^{2+}$ entry through ionotropic receptors and plasmalemmal channels, or $\mathrm{Ca}^{2+}$ influx mediated by the reverse mode of NCX [29, 361, 414].

Mechanisms underlying $\mathrm{Ca}^{2+}$ signalling differ between astrocytes from different brain regions. Local $\mathrm{Ca}^{2+}$ microdomains in Bergmann glia and in the main processes of hippocampal astrocytes were mediated solely by $\operatorname{InsP}_{3} \mathrm{Rs}[86,191]$. Local $\left[\mathrm{Ca}^{2+}\right]_{\mathrm{i}}$ transients in hippocampal astrocytes in contrast are mediated by TRPA1 channels [360]. In neocortical astrocytes $\mathrm{Ca}^{2+}$ signals involve ryanodine receptor-mediated $\left[\mathrm{Ca}^{2+}\right]_{i}$-induced $\mathrm{Ca}^{2+}$ release [284], which is not operative in hippocampal astroglia [30]. In astrocytes in vivo sensory stimulation triggers global synchronised $\mathrm{Ca}^{2+}$ signals in astrocytes in somato-sensory cortex, which depend entirely on $\operatorname{InsP}_{3} \mathrm{R} 2$ [171]. In cortical astrocytes spontaneous local $\mathrm{Ca}^{2+}$ signals in fine processes originate from $\mathrm{Ca}^{2+}$ release from mitochondria [3].

Global $\mathrm{Ca}^{2+}$ signals in the mature astrocytes in vivo are mediated by $\mathrm{a}_{1}$-adrenoceptors [88]. Similar global astroglial signalling is observed in attention and vigilance state, when widespread astrocytic responses are evoked by acetylcholine release from projection of the nucleus basalis of Meynert and are mediated through metabotropic cholinergic receptor$\mathrm{InsP}_{3}$ pathway $[67,386]$. Global astroglial $\mathrm{Ca}^{2+}$ signals spreading through the entire cortex were observed in response to transcranial direct current stimulation; these signals were mediated through $a_{1}$-adrenoceptors [247].

Astroglial propagating $\mathrm{Ca}^{2+}$ wave is mediated either by intercellular diffusion of $\mathrm{InsP}_{3}$ through gap junctions $[5,143,216]$ or through regenerative paracrine ATP-mediated signalling $[12,77,128]$ or through the combination of both [344]. Whether propagating $\mathrm{Ca}^{2+}$ waves develop in the in vivo brain in awake and behaving animals remains an open question.

\subsection{Sodium Signalling}

The concept of astroglial $\mathrm{Na}^{+}$signalling has been developed rather recently [192, 331]. Physiological stimulation triggers $\left[\mathrm{Na}^{+}\right]_{\mathrm{i}}$ transients in astrocytes in vitro $[178,329,330]$ and in situ [189, 190, 205, 328]. Generation of $\mathrm{Na}^{+}$signals is accomplished through plasmalemmal $\mathrm{Na}^{+}$entry either through plasmalemmal channels or $\mathrm{Na}^{+}$coupled SLC transporters, whereas extrusion of $\mathrm{Na}^{+}$is primarily mediated by NKA [192, 331]. Resting $\left[\mathrm{Na}^{+}\right]_{\mathrm{i}}$ in astrocytes is higher than in neurones, being in the range of $15-20 \mathrm{mM}$. 
One of the main sources for $\mathrm{Na}^{+}$influx activated in response to neuronal activity is associated with operation of EAATs that co-transport $3 \mathrm{Na}^{+}$with 1 glutamate; increase in extracellular glutamate may increase $\left[\mathrm{Na}^{+}\right]_{\mathrm{i}}$ by $10-30 \mathrm{mM}[35,65,190]$. Sodium influx may also be mediated by GABA transporters, ionotropic receptors, by TRP channels or by NCX operating in the forward mode [189, 205, 323]. Sodium entry may produce long-lasting [ $\mathrm{Na}$ $\left.{ }^{+}\right]_{\mathrm{i}}$ microdomains which, as per computational modelling, may be facilitated by fairly negative resting potential of astroglial plasmalemma [51]. Propagating $\mathrm{Na}^{+}$waves have been also detected in astrocytes in culture and in situ in hippocampal slices; these waves are propagating through gap junctions [206].

Astroglial $\mathrm{Na}^{+}$signals regulate multiple SLC transporters sensitive to transmembrane $\mathrm{Na}^{+}$ gradients (Fig. 3.9); $\left[\mathrm{Na}^{+}\right]_{\mathrm{i}}$ also regulates glutamine-glutamate (GABA) shuttle through direct action on glutamine synthetase [34] and regulation of glutamine transporters [397]. Changes in $\left[\mathrm{Na}^{+}\right]_{\mathrm{i}}$ regulate $\mathrm{K}^{+}$buffering through the NKA transport and $\mathrm{pH}$ homeostasis by regulating NBC and NHE. By controlling reversal potential of NCX, astroglial $\mathrm{Na}^{+}$signals may contribute to $\mathrm{Ca}^{2+}$ signalling by initiating local $\mathrm{Ca}^{2+}$ influx in distal processes. Finally, fluctuations of $\left[\mathrm{Na}^{+}\right]_{\mathrm{i}}$ are coupled to astroglial metabolism, through controlling glycolysis and lactate production and possibly regulating ATP synthesis [64]. The sodium signalling system thus provides for fast coordination of neuronal activity with 'homeostatic' response of astroglia mediated through $\mathrm{Na}^{+}$-dependent transporters, concentrated in perisynaptic processes.

\subsection{Summary}

Astroglial physiology is defined by a complement of ion channels, receptors for neurotransmitters, and neurohormones and membrane transporter systems. High expression of $\mathrm{K}^{+}$channels stabilises the membrane potential at negative level, thus ensuring electrodriving forces for operation of membrane transporters. Multiple receptors for neuroactive agents on astrocytes provide for input signals reflecting upon neuronal activity. Astrocytic ionic signalling regulates operation of transporters responsible for astroglial homeostatic response, central for astrocytic support of neuronal networks.

\section{Acknowledgments}

VP's work is supported by a grant from the National Institute of General Medical Sciences of the National Institutes of Health (R01GM123971). VP is an Honorary Professor at University of Rijeka, Croatia.

\section{References}

1. Abbracchio MP, Ceruti S (2006) Roles of P2 receptors in glial cells: focus on astrocytes. Purinergic Signal 2:595-604 [PubMed: 18404462]

2. Adermark L, Lovinger DM (2008) Electrophysiological properties and gap junction coupling of striatal astrocytes. Neurochem Int 52:1365-1372 [PubMed: 18396351]

3. Agarwal A, Wu PH, Hughes EG, Fukaya M, Tischfield MA, Langseth AJ, Wirtz D, Bergles DE (2017) Transient opening of the mitochondrial permeability transition pore induces microdomain calcium transients in astrocyte processes. Neuron 93(587-605):e587

4. Agulhon C, Fiacco TA, McCarthy KD (2010) Hippocampal short- and long-term plasticity are not modulated by astrocyte $\mathrm{Ca}^{2+}$ signaling. Science 327:1250-1254 [PubMed: 20203048] 
5. Allbritton NL, Meyer T, Stryer L (1992) Range of messenger action of calcium ion and inositol 1,4,5-trisphosphate. Science 258:1812-1815 [PubMed: 1465619]

6. Allen A, Messier C (2013) Plastic changes in the astrocyte GLUT1 glucose transporter and betatubulin microtubule protein following voluntary exercise in mice. Behav Brain Res 240:95-102 [PubMed: 23201358]

7. Allen JW, Shanker G, Aschner M (2001) Methylmercury inhibits the in vitro uptake of the glutathione precursor, cystine, in astrocytes, but not in neurons. Brain Res 894:131-140 [PubMed: 11245823]

8. Altevogt BM, Paul DL (2004) Four classes of intercellular channels between glial cells in the CNS. J Neurosci 24:4313-4323 [PubMed: 15128845]

9. Alvarez-Maubecin V, Garcia-Hernandez F, Williams JT, Van Bockstaele EJ (2000) Functional coupling between neurons and glia. J Neurosci 20:4091-4098 [PubMed: 10818144]

10. Amin MS, Wang HW, Reza E, Whitman SC, Tuana BS, Leenen FH (2005) Distribution of epithelial sodium channels and mineralocorticoid receptors in cardiovascular regulatory centers in rat brain. Am J Physiol Regul Integr Comp Physiol 289:R1787-R1797 [PubMed: 16141309]

11. Amzica F, Massimini M (2002) Glial and neuronal interactions during slow wave and paroxysmal activities in the neocortex. Cereb Cortex 12:1101-1113 [PubMed: 12217974]

12. Anderson CM, Bergher JP, Swanson RA (2004) ATP-induced ATP release from astrocytes. J Neurochem 88:246-256 [PubMed: 14675168]

13. Andriezen WL (1893) The neuroglia elements of the brain. Br Med J 2:227-230

14. Aoki C, Venkatesan C, Kurose H (1998) Noradrenergic modulation of the prefrontal cortex as revealed by electron microscopic immunocytochemistry. Adv Pharmacol 42:777-780 [PubMed: 9328013]

15. Araque A, Martin ED, Perea G, Arellano JI, Buno W (2002) Synaptically released acetylcholine evokes $\mathrm{Ca}^{2+}$ elevations in astrocytes in hippocampal slices. J Neurosci 22:2443-2450 [PubMed: 11923408]

16. Arbones L, Picatoste F, Garcia A (1990) Histamine stimulates glycogen breakdown and increases ${ }^{45} \mathrm{Ca}^{2+}$ permeability in rat astrocytes in primary culture. Mol Pharmacol 37:921-927 [PubMed: 2163018]

17. Armstrong WE, Rubrum A, Teruyama R, Bond CT, Adelman JP (2005) Immunocytochemical localization of small-conductance, calcium-dependent potassium channels in astrocytes of the rat supraoptic nucleus. J Comp Neurol 491:175-185 [PubMed: 16134141]

18. Ashour F, Deuchars J (2004) Electron microscopic localisation of $\mathrm{P} 2 \mathrm{X}_{4}$ receptor subunit immunoreactivity to pre- and post-synaptic neuronal elements and glial processes in the dorsal vagal complex of the rat. Brain Res 1026:44-55 [PubMed: 15476696]

19. Azmitia EC, Gannon PJ, Kheck NM, Whitaker-Azmitia PM (1996) Cellular localization of the 5$\mathrm{HT}_{1 \mathrm{~A}}$ receptor in primate brain neurons and glial cells. Neuropsychopharmacology 14:35-46 [PubMed: 8719028]

20. Babu AN, Cheng TP, Zhang A, Altura BT, Altura BM (1999) Low concentrations of ethanol deplete type-2 astrocytes of intracellular free magnesium. Brain Res Bull 50:59-62 [PubMed: 10507473]

21. Badaut J, Hirt L, Granziera C, Bogousslavsky J, Magistretti PJ, Regli L (2001) Astrocytespecific expression of aquaporin-9 in mouse brain is increased after transient focal cerebral ischemia. $\mathrm{J}$ Cereb Blood Flow Metab 21:477-482 [PubMed: 11333357]

22. Bai JZ, Lipski J (2010) Differential expression of TRPM2 and TRPV4 channels and their potential role in oxidative stress-induced cell death in organotypic hippocampal culture. Neurotoxicology 31:204-214 [PubMed: 20064552]

23. Bal A, Bachelot T, Savasta M, Manier M, Verna JM, Benabid AL, Feuerstein C (1994) Evidence for dopamine $\mathrm{D}_{2}$ receptor mRNA expression by striatal astrocytes in culture: in situ hybridization and polymerase chain reaction studies. Brain Res Mol Brain Res 23:204-212 [PubMed: 8057777]

24. Ballerini P, Rathbone MP, Di Iorio P, Renzetti A, Giuliani P, D’Alimonte I, Trubiani O, Caciagli F, Ciccarelli R (1996) Rat astroglial P2Z $\left(\mathrm{P}_{2} \mathrm{X}_{7}\right)$ receptors regulate intracellular calcium and purine release. NeuroReport 7:2533-2537 [PubMed: 8981418] 
25. Barcelo-Torns M, Lewis AM, Gubern A, Barneda D, Bloor-Young D, Picatoste F, Churchill GC, Claro E, Masgrau R (2011) NAADP mediates ATP-induced $\mathrm{Ca}^{2+}$ signals in astrocytes. FEBS Lett 585:2300-2306 [PubMed: 21664355]

26. Barres BA, Chun LL, Corey DP (1988) Ion channel expression by white matter glia: I. Type 2 astrocytes and oligodendrocytes. Glia 1:10-30 [PubMed: 2466789]

27. Barres BA, Chun LL, Corey DP (1989) Calcium current in cortical astrocytes: induction by cAMP and neurotransmitters and permissive effect of serum factors. J Neurosci 9:3169-3175 [PubMed: 2571687]

28. Barres BA, Chun LL, Corey DP (1989) Glial and neuronal forms of the voltage-dependent sodium channel: characteristics and cell-type distribution. Neuron 2:1375-1388 [PubMed: 2560639]

29. Bazargani N, Attwell D (2016) Astrocyte calcium signaling: the third wave. Nat Neurosci 19:182189 [PubMed: 26814587]

30. Beck A, Nieden RZ, Schneider HP, Deitmer JW (2004) Calcium release from intracellular stores in rodent astrocytes and neurons in situ. Cell Calcium 35:47-58 [PubMed: 14670371]

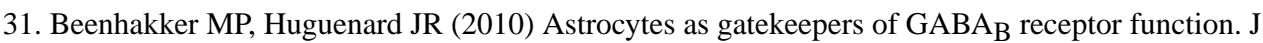
Neurosci 30:15262-15276 [PubMed: 21068331]

32. Bekar LK, Loewen ME, Cao K, Sun X, Leis J, Wang R, Forsyth GW, Walz W (2005) Complex expression and localization of inactivating $\mathrm{K}_{\mathrm{V}}$ channels in cultured hippocampal astrocytes. $\mathrm{J}$ Neurophysiol 93:1699-1709 [PubMed: 15738276]

33. Benfenati V, Amiry-Moghaddam M, Caprini M, Mylonakou MN, Rapisarda C, Ottersen OP, Ferroni S (2007) Expression and functional characterization of transient receptor potential vanilloid-related channel 4 (TRPV4) in rat cortical astrocytes. Neuroscience 148:876-892 [PubMed: 17719182]

34. Benjamin AM (1987) Influence of $\mathrm{Na}^{+}, \mathrm{K}^{+}$, and $\mathrm{Ca}^{2+}$ on glutamine synthesis and distribution in rat brain cortex slices: a possible linkage of glutamine synthetase with cerebral transport processes and energetics in the astrocytes. J Neurochem 48:1157-1164 [PubMed: 2434618]

35. Bennay M, Langer J, Meier SD, Kafitz KW, Rose CR (2008) Sodium signals in cerebellar Purkinje neurons and Bergmann glial cells evoked by glutamatergic synaptic transmission. Glia 56:11381149 [PubMed: 18442095]

36. Bennett GC, Ford AP, Smith JA, Emmett CJ, Webb TE, Boarder MR (2003) P2Y receptor regulation of cultured rat cerebral cortical cells: calcium responses and mRNA expression in neurons and glia. Br J Pharmacol 139:279-288 [PubMed: 12770933]

37. Berger UV, Hediger MA (2000) Distribution of the glutamate transporters GLAST and GLT-1 in rat circumventricular organs, meninges, and dorsal root ganglia. J Comp Neurol 421:385-399 [PubMed: 10813794]

38. Bernstein M, Behnisch T, Balschun D, Reymann KG, Reiser G (1998) Pharmacological characterisation of metabotropic glutamatergic and purinergic receptors linked to $\mathrm{Ca}^{2+}$ signalling in hippocampal astrocytes. Neuropharmacology 37:169-178 [PubMed: 9680241]

39. Binder DK, Yao X, Zador Z, Sick TJ, Verkman AS, Manley GT (2006) Increased seizure duration and slowed potassium kinetics in mice lacking aquaporin-4 water channels. Glia 53:631-636 [PubMed: 16470808]

40. Black JA, Dib-Hajj S, Cohen S, Hinson AW, Waxman SG (1998) Glial cells have heart: rH1 Na ${ }^{+}$ channel mRNA and protein in spinal cord astrocytes. Glia 23:200-208 [PubMed: 9633805]

41. Black JA, Newcombe J, Waxman SG (2010) Astrocytes within multiple sclerosis lesions upregulate sodium channel $\mathrm{Na}_{\mathrm{V}}$ 1.5. Brain 133:835-846 [PubMed: 20147455]

42. Black JA, Sontheimer H, Minturn JE, Ransom BR, Waxman SG (1992) The expression of sodium channels in astrocytes in situ and in vitro. Prog Brain Res 94:89-107 [PubMed: 1337617]

43. Black JA, Waxman SG (2013) Noncanonical roles of voltage-gated sodium channels. Neuron 80:280-291 [PubMed: 24139034]

44. Black JA, Westenbroek R, Minturn JE, Ransom BR, Catterall WA, Waxman SG (1995) Isoformspecific expression of sodium channels in astrocytes in vitro: immunocytochemical observations. Glia 14:133-144 [PubMed: 7558240] 
45. Blaustein MP, Juhaszova M, Golovina VA, Church PJ, Stanley EF (2002) Na/Ca exchanger and PMCA localization in neurons and astrocytes: functional implications. Ann NY Acad Sci 976:356-366 [PubMed: 12502582]

46. Blazquez C, Sanchez C, Daza A, Galve-Roperh I, Guzman M (1999) The stimulation of ketogenesis by cannabinoids in cultured astrocytes defines carnitine palmitoyltransferase I as a new ceramide-activated enzyme. J Neurochem 72:1759-1768 [PubMed: 10098887]

47. Blomstrand F, Giaume C, Hansson E, Ronnback L (1999) Distinct pharmacological properties of ET-1 and ET-3 on astroglial gap junctions and $\mathrm{Ca}^{(2+)}$ signaling. Am J Physiol 277:C616-C627 [PubMed: 10516091]

48. Bordey A, Sontheimer H (2000) Ion channel expression by astrocytes in situ: comparison of different CNS regions. Glia 30:27-38 [PubMed: 10696142]

49. Bramham CR, Torp R, Zhang N, Storm-Mathisen J, Ottersen OP (1990) Distribution of glutamatelike immunoreactivity in excitatory hippocampal pathways: a semiquantitative electron microscopic study in rats. Neuroscience 39:405-417 [PubMed: 2087264]

50. Brasko C, Hawkins V, De La Rocha IC, Butt AM (2016) Expression of $\mathrm{K}_{\mathrm{ir}} 4.1$ and $\mathrm{K}_{\mathrm{ir}} 5.1$ inwardly rectifying potassium channels in oligodendrocytes, the myelinating cells of the CNS. Brain Struct Funct

51. Breslin K, Wade JJ, Wong-Lin K, Harkin J, Flanagan B, Van Zalinge H, Hall S, Walker M, Verkhratsky A, McDaid L (2018) Potassium and sodium microdomains in thin astroglial processes: a computational model study. PLoS Comput Biol 14:e1006151 [PubMed: 29775457]

52. Brito V, Beyer C, Kuppers E (2004) BDNF-dependent stimulation of dopamine $\mathrm{D}_{5}$ receptor expression in developing striatal astrocytes involves PI3-kinase signaling. Glia 46:284-295 [PubMed: 15048851]

53. Brodie C (1994) Functional PAF receptors in glia cells: binding parameters and regulation of expression. Int J Dev Neurosci 12:631-640 [PubMed: 7900545]

54. Brodie C (1995) Platelet activating factor induces nerve growth factor production by rat astrocytes. Neurosci Lett 186:5-8 [PubMed: 7783948]

55. Brune T, Deitmer JW (1995) Intracellular acidification and $\mathrm{Ca}^{2+}$ transients in cultured rat cerebellar astrocytes evoked by glutamate agonists and noradrenaline. Glia 14:153-161 [PubMed: 7558242]

56. Bruner G, Murphy S (1993) UTP activates multiple second messenger systems in cultured rat astrocytes. Neurosci Lett 162:105-108 [PubMed: 8121609]

57. Butenko O, Dzamba D, Benesova J, Honsa P, Benfenati V, Rusnakova V, Ferroni S, Anderova M (2012) The increased activity of TRPV4 channel in the astrocytes of the adult rat hippocampus after cerebral hypoxia/ischemia. PLoS ONE 7:e39959 [PubMed: 22761937]

58. Butt AM, Kalsi A (2006) Inwardly rectifying potassium channels $\left(\mathrm{K}_{\mathrm{ir}}\right)$ in central nervous system glia: a special role for $\mathrm{K}_{\mathrm{ir}} 4.1$ in glial functions. J Cell Mol Med 10:33-44 [PubMed: 16563220]

59. Butt AM, Ransom BR (1989) Visualization of oligodendrocytes and astrocytes in the intact rat optic nerve by intracellular injection of lucifer yellow and horseradish peroxidase. Glia 2:470-475 [PubMed: 2531727]

60. Cahoy JD, Emery B, Kaushal A, Foo LC, Zamanian JL, Christopherson KS, Xing Y, Lubischer JL, Krieg PA, Krupenko SA, Thompson WJ, Barres BA (2008) A transcriptome database for astrocytes, neurons, and oligodendrocytes: a new resource for understanding brain development and function. J Neurosci 28:264-278 [PubMed: 18171944]

61. Carson MJ, Thomas EA, Danielson PE, Sutcliffe JG (1996) The 5HT5A serotonin receptor is expressed predominantly by astrocytes in which it inhibits cAMP accumulation: a mechanism for neuronal suppression of reactive astrocytes. Glia 17:317-326 [PubMed: 8856328]

62. Catus SL, Gibbs ME, Sato M, Summers RJ, Hutchinson DS (2011) Role of $\beta$-adrenoceptors in glucose uptake in astrocytes using beta-adrenoceptor knockout mice. Br J Pharmacol 162:1700 1715 [PubMed: 21138422]

63. Charles AC, Merrill JE, Dirksen ER, Sanderson MJ (1991) Intercellular signaling in glial cells: calcium waves and oscillations in response to mechanical stimulation and glutamate. Neuron 6:983-992 [PubMed: 1675864] 
64. Chatton JY, Magistretti PJ, Barros LF (2016) Sodium signaling and astrocyte energy metabolism. Glia 64:1667-1676 [PubMed: 27027636]

65. Chatton JY, Pellerin L, Magistretti PJ (2003) GABA uptake into astrocytes is not associated with significant metabolic cost: implications for brain imaging of inhibitory transmission. Proc Natl Acad Sci USA 100:12456-12461 [PubMed: 14530410]

66. Chaudhry FA, Lehre KP, van Lookeren Campagne M, Ottersen OP, Danbolt NC, Storm-Mathisen J (1995) Glutamate transporters in glial plasma membranes: highly differentiated localizations revealed by quantitative ultrastructural immunocytochemistry. Neuron 15:711-720 [PubMed: 7546749]

67. Chen N, Sugihara H, Sharma J, Perea G, Petravicz J, Le C, Sur M (2012) Nucleus basalisenabled stimulus-specific plasticity in the visual cortex is mediated by astrocytes. Proc Natl Acad Sci USA 109:E2832-E2841 [PubMed: 23012414]

68. Chen Y, Rathbone MP, Hertz L (2001) Guanosine-induced increase in free cytosolic calcium concentration in mouse astrocytes in primary cultures: does it act on an $\mathrm{A}_{3}$ adenosine receptor? $\mathrm{J}$ Neurosci Res 65:184-189 [PubMed: 11438987]

69. Chesler M (2003) Regulation and modulation of $\mathrm{pH}$ in the brain. Physiol Rev 83:1183-1221 [PubMed: 14506304]

70. Cho Y, Bannai S (1990) Uptake of glutamate and cysteine in C-6 glioma cells and in cultured astrocytes. J Neurochem 55:2091-2097 [PubMed: 1977889]

71. Cholewinski AJ, Stevens G, McDermott AM, Wilkin GP (1991) Identification of $B_{2}$ bradykinin binding sites on cultured cortical astrocytes. J Neurochem 57:1456-1458 [PubMed: 1895115]

72. Chun LLY, Barres BA, Corey DP (1986) Induction of a calcium channel in astrocytes by cAMP. Soc Neurosci Abs 12:1346

73. Chvatal A, Pastor A, Mauch M, Sykova E, Kettenmann H (1995) Distinct populations of identified glial cells in the developing rat spinal cord slice: ion channel properties and cell morphology. Eur J Neurosci 7:129-142 [PubMed: 7536092]

74. Clark B, Mobbs P (1992) Transmitter-operated channels in rabbit retinal astrocytes studied in situ by whole-cell patch clamping. J Neurosci 12:664-673 [PubMed: 1371317]

75. Conti F, Minelli A, Brecha NC (1994) Cellular localization and laminar distribution of AMPA glutamate receptor subunits mRNAs and proteins in the rat cerebral cortex. J Comp Neurol 350:241-259 [PubMed: 7884041]

76. Cornell-Bell AH, Finkbeiner SM, Cooper MS, Smith SJ (1990) Glutamate induces calcium waves in cultured astrocytes: long-range glial signaling. Science 247:470-473 [PubMed: 1967852]

77. Cotrina ML, Lin JH, Lopez-Garcia JC, Naus CC, Nedergaard M (2000) ATP-mediated glia signaling. J Neurosci 20:2835-2844 [PubMed: 10751435]

78. Dahl G (2015) ATP release through pannexon channels. Philos Trans R Soc Lond B Biol Sci 370

79. Dall'Aglio C, Ceccarelli P, Pascucci L, Brecchia G, Boiti C (2006) Receptors for leptin and estrogen in the subcommissural organ of rabbits are differentially modulated by fasting. Brain Res 1124:62-69 [PubMed: 17084823]

80. Dallaporta M, Pecchi E, Pio J, Jean A, Horner KC, Troadec JD (2009) Expression of leptin receptor by glial cells of the nucleus tractus solitarius: possible involvement in energy homeostasis. J Neuroendocrinol 21:57-67 [PubMed: 19094094]

81. Dallerac G, Chever O, Rouach N (2013) How do astrocytes shape synaptic transmission? Insights from electrophysiology. Front Cell Neurosci 7:159 [PubMed: 24101894]

82. Danbolt NC (2001) Glutamate uptake. Prog Neurobiol 65:1-105 [PubMed: 11369436]

83. Dani JW, Chernjavsky A, Smith SJ (1992) Neuronal activity triggers calcium waves in hippocampal astrocyte networks. Neuron 8:429-440 [PubMed: 1347996]

84. Dare E, Schulte G, Karovic O, Hammarberg C, Fredholm BB (2007) Modulation of glial cell functions by adenosine receptors. Physiol Behav 92:15-20 [PubMed: 17574632]

85. Deitmer JW, Rose CR (1996) $\mathrm{pH}$ regulation and proton signalling by glial cells. Prog Neurobiol 48:73-103 [PubMed: 8737439] 
86. Di Castro MA, Chuquet J, Liaudet N, Bhaukaurally K, Santello M, Bouvier D, Tiret P, Volterra A (2011) Local $\mathrm{Ca}^{2+}$ detection and modulation of synaptic release by astrocytes. Nat Neurosci 14:1276-1284 [PubMed: 21909085]

87. Di Scala-Guenot D, Mouginot D, Strosser MT (1994) Increase of intracellular calcium induced by oxytocin in hypothalamic cultured astrocytes. Glia 11:269-276 [PubMed: 7960031]

88. Ding F, O’Donnell J, Thrane AS, Zeppenfeld D, Kang H, Xie L, Wang F, Nedergaard M (2013) $\mathrm{a}_{1}$-Adrenergic receptors mediate coordinated $\mathrm{Ca}^{2+}$ signaling of cortical astrocytes in awake, behaving mice. Cell Calcium 54:387-394 [PubMed: 24138901]

89. Dixon SJ, Yu R, Panupinthu N, Wilson JX (2004) Activation of P2 nucleotide receptors stimulates acid efflux from astrocytes. Glia 47:367-376 [PubMed: 15293234]

90. Doengi M, Deitmer JW, Lohr C (2008) New evidence for purinergic signaling in the olfactory bulb: $\mathrm{A}_{2 \mathrm{~A}}$ and $\mathrm{P}_{2} \mathrm{Y}_{1}$ receptors mediate intracellular calcium release in astrocytes. FASEB J 22:23682378 [PubMed: 18310463]

91. Doly S, Fischer J, Salio C, Conrath M (2004) The vanilloid receptor-1 is expressed in rat spinal dorsal horn astrocytes. Neurosci Lett 357:123-126 [PubMed: 15036590]

92. Dong JH, Chen X, Cui M, Yu X, Pang Q, Sun JP (2012) $\beta_{2}$-adrenergic receptor and astrocyte glucose metabolism. J Mol Neurosci 48:456-463 [PubMed: 22399228]

93. Duan S, Anderson CM, Keung EC, Chen Y, Swanson RA (2003) P2X 7 receptor-mediated release of excitatory amino acids from astrocytes. J Neurosci 23:1320-1328 [PubMed: 12598620]

94. Duan S, Neary JT (2006) P2X 7 receptors: properties and relevance to CNS function. Glia 54:738746 [PubMed: 17006902]

95. Dzamba D, Honsa P, Valny M, Kriska J, Valihrach L, Novosadova V, Kubista M, Anderova M (2015) Quantitative analysis of glutamate receptors in glial cells from the cortex of GFAP/EGFP mice following ischemic injury: focus on NMDA receptors. Cell Mol Neurobiol 35:1187-1202 [PubMed: 25994914]

96. Eaton MJ, Skatchkov SN, Brune A, Biedermann B, Veh RW, Reichenbach A (2002) SURI and $\mathrm{K}_{\mathrm{ir}} 6.1$ subunits of $\mathrm{K}_{\mathrm{ATP}}$-channels are co-localized in retinal glial (Muller) cells. NeuroReport 13:57-60 [PubMed: 11924895]

97. Edwards L, Nashmi R, Jones O, Backx P, Ackerley C, Becker L, Fehlings MG (2002) Upregulation of $K_{\mathrm{V}} 1.4$ protein and gene expression after chronic spinal cord injury. J Comp Neurol 443:154167 [PubMed: 11793353]

98. Emmi A, Wenzel HJ, Schwartzkroin PA, Taglialatela M, Castaldo P, Bianchi L, Nerbonne J, Robertson GA, Janigro D (2000) Do glia have heart? Expression and functional role for ether-ago-go currents in hippocampal astrocytes. J Neurosci 20:3915-3925 [PubMed: 10804231]

99. Enkvist MO, Holopainen I, Akerman KE (1989) Glutamate receptor-linked changes in membrane potential and intracellular $\mathrm{Ca}^{2+}$ in primary rat astrocytes. Glia 2:397-402 [PubMed: 2574162]

100. Enyedi P, Czirjak G (2010) Molecular background of leak $\mathrm{K}^{+}$currents: two-pore domain potassium channels. Physiol Rev 90:559-605 [PubMed: 20393194]

101. Eriksson PS, Hansson E, Ronnback L (1990) $\delta$ and $\kappa$ opiate receptors in primary astroglial cultures from rat cerebral cortex. Neurochem Res 15:1123-1126 [PubMed: 1982460]

102. Eriksson PS, Hansson E, Ronnback L (1992) $\delta$ and $\kappa$ opiate receptors in primary astroglial cultures. Part II: Receptor sets in cultures from various brain regions and interactions with betareceptor activated cyclic AMP. Neurochem Res 17:545-551 [PubMed: 1318509]

103. Eriksson PS, Nilsson M, Wagberg M, Hansson E, Ronnback L (1993) א-opioid receptors on astrocytes stimulate L-type $\mathrm{Ca}^{2+}$ channels. Neuroscience 54:401-407 [PubMed: 8393154]

104. Fam SR, Gallagher CJ, Salter MW (2000) $\mathrm{P}_{2} \mathrm{Y}_{1}$ purinoceptor-mediated $\mathrm{Ca}^{2+}$ signaling and $\mathrm{Ca}^{2+}$ wave propagation in dorsal spinal cord astrocytes. J Neurosci 20:2800-2808 [PubMed: 10751431]

105. Fang Q, Hu WW, Wang XF, Yang Y, Lou GD, Jin MM, Yan HJ, Zeng WZ, Shen Y, Zhang SH, Xu TL, Chen Z (2014) Histamine up-regulates astrocytic glutamate transporter 1 and protects neurons against ischemic injury. Neuropharmacology 77:156-166 [PubMed: 23791559]

106. Fellin T, Pozzan T, Carmignoto G (2006) Purinergic receptors mediate two distinct glutamate release pathways in hippocampal astrocytes. J Biol Chem 281:4274-4284 [PubMed: 16338906] 
107. Filosa JA, Bonev AD, Straub SV, Meredith AL, Wilkerson MK, Aldrich RW, Nelson MT (2006) Local potassium signaling couples neuronal activity to vasodilation in the brain. Nat Neurosci 9:1397-1403 [PubMed: 17013381]

108. Finkbeiner S (1992) Calcium waves in astrocytes-filling in the gaps. Neuron 8:1101-1108 [PubMed: 1351732]

109. Franke H, Grosche J, Schadlich H, Krugel U, Allgaier C, Illes P (2001) P2X receptor expression on astrocytes in the nucleus accumbens of rats. Neuroscience 108:421-429 [PubMed: 11738256]

110. Franke H, Gunther A, Grosche J, Schmidt R, Rossner S, Reinhardt R, Faber-Zuschratter H, Schneider D, Illes P (2004) $\mathrm{P}_{2} \mathrm{X}_{7}$ receptor expression after ischemia in the cerebral cortex of rats. J Neuropathol Exp Neurol 63:686-699 [PubMed: 15290894]

111. Franke H, Verkhratsky A, Burnstock G, Illes P (2012) Pathophysiology of astroglial purinergic signalling. Purinergic Signal 8:629-657 [PubMed: 22544529]

112. Fraser DD, Duffy S, Angelides KJ, Perez-Velazquez JL, Kettenmann H, MacVicar BA (1995) $\mathrm{GABA}_{\mathrm{A}}$ /benzodiazepine receptors in acutely isolated hippocampal astrocytes. J Neurosci 15:2720-2732 [PubMed: 7722625]

113. Fumagalli M, Brambilla R, D'Ambrosi N, Volonte C, Matteoli M, Verderio C, Abbracchio MP (2003) Nucleotide-mediated calcium signaling in rat cortical astrocytes: role of P2X and P2Y receptors. Glia 43:218-230 [PubMed: 12898701]

114. Garcia-Caceres C, Quarta C, Varela L, Gao Y, Gruber T, Legutko B, Jastroch M, Johansson P, Ninkovic J, Yi CX, Le Thuc O, Szigeti-Buck K, Cai W, Meyer CW, Pfluger PT, Fernandez AM, Luquet S, Woods SC, Torres-Aleman I, Kahn CR, Gotz M, Horvath TL, Tschop MH (2016) Astrocytic insulin signaling couples brain glucose uptake with nutrient availability. Cell 166:867880 [PubMed: 27518562]

115. Geiger JR, Melcher T, Koh DS, Sakmann B, Seeburg PH, Jonas P, Monyer H (1995) Relative abundance of subunit mRNAs determines gating and $\mathrm{Ca}^{2+}$ permeability of AMPA receptors in principal neurons and interneurons in rat CNS. Neuron 15:193-204 [PubMed: 7619522]

116. Giaume C, Cordier J, Glowinski J (1992) Endothelins inhibit junctional permeability in cultured mouse astrocytes. Eur J Neurosci 4:877-881 [PubMed: 12106311]

117. Giaume C, Fromaget C, el Aoumari A, Cordier J, Glowinski J, Gros D (1991) Gap junctions in cultured astrocytes: single-channel currents and characterization of channel-forming protein. Neuron 6:133-143 [PubMed: 1702648]

118. Giaume C, Koulakoff A, Roux L, Holcman D, Rouach N (2010) Astroglial networks: a step further in neuroglial and gliovascular interactions. Nat Rev Neurosci 11:87-99 [PubMed: 20087359]

119. Giaume C, Leybaert L, Naus CC, Saez JC (2013) Connexin and pannexin hemichannels in brain glial cells: properties, pharmacology, and roles. Front Pharmacol 4:88 [PubMed: 23882216]

120. Golovina VA, Bambrick LL, Yarowsky PJ, Krueger BK, Blaustein MP (1996) Modulation of two functionally distinct $\mathrm{Ca}^{2+}$ stores in astrocytes: role of the plasmalemmal $\mathrm{Na} / \mathrm{Ca}$ exchanger. Glia 16:296-305 [PubMed: 8721670]

121. Graham AJ, Ray MA, Perry EK, Jaros E, Perry RH, Volsen SG, Bose S, Evans N, Lindstrom J, Court JA (2003) Differential nicotinic acetylcholine receptor subunit expression in the human hippocampus. J Chem Neuroanat 25:97-113 [PubMed: 12663058]

122. Grichtchenko II, Chesler M (1994) Depolarization-induced alkalinization of astrocytes in gliotic hippocampal slices. Neuroscience 62:1071-1078 [PubMed: 7845587]

123. Griemsmann S, Hoft SP, Bedner P, Zhang J, von Staden E, Beinhauer A, Degen J, Dublin P, Cope DW, Richter N, Crunelli V, Jabs R, Willecke K, Theis M, Seifert G, Kettenmann H, Steinhauser $\mathrm{C}$ (2015) Characterization of panglial gap junction networks in the thalamus, neocortex, and hippocampus reveals a unique population of glial cells. Cereb Cortex 25:3420-3433 [PubMed: 25037920]

124. Grimaldi M, Maratos M, Verma A (2003) Transient receptor potential channel activation causes a novel form of $\left[\mathrm{Ca}^{2+}\right]_{\mathrm{i}}$ oscillations and is not involved in capacitative $\mathrm{Ca}^{2+}$ entry in glial cells. $\mathrm{J}$ Neurosci 23:4737-4745 [PubMed: 12805313] 
125. Grolla AA, Sim JA, Lim D, Rodriguez JJ, Genazzani AA, Verkhratsky A (2013) Amyloid- $\beta$ and Alzheimer's disease type pathology differentially affects the calcium signalling toolkit in astrocytes from different brain regions. Cell Death Dis 4:e623 [PubMed: 23661001]

126. Halestrap AP (2012) The monocarboxylate transporter family-structure and functional characterization. IUBMB Life 64:1-9 [PubMed: 22131303]

127. Han KS, Mannaioni G, Hamill CE, Lee J, Junge CE, Lee CJ, Traynelis SF (2011) Activation of protease activated receptor 1 increases the excitability of the dentate granule neurons of hippocampus. Mol Brain. 4:32 [PubMed: 21827709]

128. Hassinger TD, Guthrie PB, Atkinson PB, Bennet MVL, Kater SB (1997) An extracellular signaling component in propagation of astrocytic calcium waves. Proc Natl Acad Sci USA 93:13268-13273

129. Hatton GI, Bicknell RJ, Hoyland J, Bunting R, Mason WT (1992) Arginine vasopressin mobilises intracellular calcium via $\mathrm{V}_{1}$-receptor activation in astrocytes (pituicytes) cultured from adult rat neural lobes. Brain Res 588:75-83 [PubMed: 1393572]

130. Haustein MD, Kracun S, Lu XH, Shih T, Jackson-Weaver O, Tong X, Xu J, Yang XW, O'Dell TJ, Marvin JS, Ellisman MH, Bushong EA, Looger LL, Khakh BS (2014) Conditions and constraints for astrocyte calcium signaling in the hippocampal mossy fiber pathway. Neuron 82:413-429 [PubMed: 24742463]

131. Heni M, Hennige AM, Peter A, Siegel-Axel D, Ordelheide AM, Krebs N, Machicao F, Fritsche A, Haring HU, Staiger H (2011) Insulin promotes glycogen storage and cell proliferation in primary human astrocytes. PLoS ONE 6:e21594 [PubMed: 21738722]

132. Herman MA, Jahr CE (2007) Extracellular glutamate concentration in hippocampal slice. J Neurosci 27:9736-9741 [PubMed: 17804634]

133. Hertle DN, Yeckel MF (2007) Distribution of inositol-1,4,5-trisphosphate receptor isotypes and ryanodine receptor isotypes during maturation of the rat hippocampus. Neuroscience 150:625638 [PubMed: 17981403]

134. Hertz L, Gerkau NJ, Xu J, Durry S, Song D, Rose CR, Peng L (2015) Roles of astrocytic $\mathrm{Na}^{+}, \mathrm{K}$ ${ }^{+}$-ATPase and glycogenolysis for $\mathrm{K}^{+}$homeostasis in mammalian brain. J Neurosci Res 93:10191030 [PubMed: 25352321]

135. Hertz L, Lovatt D, Goldman SA, Nedergaard M (2010) Adrenoceptors in brain: cellular gene expression and effects on astrocytic metabolism and $\left[\mathrm{Ca}^{2+}\right]_{\mathrm{i}}$. Neurochem Int 57:411-420 [PubMed: 20380860]

136. Hertz L, Rothman DL, Li B, Peng L (2015) Chronic SSRI stimulation of astrocytic 5-HT $2 B$ receptors change multiple gene expressions/editings and metabolism of glutamate, glucose and glycogen: a potential paradigm shift. Front Behav Neurosci 9:25 [PubMed: 25750618]

137. Hertz L, Song D, Xu J, Peng L, Gibbs ME (2015) Role of the astrocytic $\mathrm{Na}^{+}, \mathrm{K}^{+}$-ATPase in $\mathrm{K}^{+}$ homeostasis in brain: $\mathrm{K}^{+}$uptake, signaling pathways and substrate utilization. Neurochem Res 40:2505-2516 [PubMed: 25555706]

138. Hibino H, Fujita A, Iwai K, Yamada M, Kurachi Y (2004) Differential assembly of inwardly rectifying $\mathrm{K}^{+}$channel subunits, $\mathrm{K}_{\mathrm{ir}} 4.1$ and $\mathrm{K}_{\mathrm{ir}}$ 5.1, in brain astrocytes. J Biol Chem 279:4406544073 [PubMed: 15310750]

139. Hibino H, Inanobe A, Furutani K, Murakami S, Findlay I, Kurachi Y (2010) Inwardly rectifying potassium channels: their structure, function, and physiological roles. Physiol Rev 90:291-366 [PubMed: 20086079]

140. Higashi K, Fujita A, Inanobe A, Tanemoto M, Doi K, Kubo T, Kurachi Y (2001) An inwardly rectifying $\mathrm{K}^{+}$channel, $\mathrm{K}_{\mathrm{ir}} 4.1$, expressed in astrocytes surrounds synapses and blood vessels in brain. Am J Physiol Cell Physiol 281:C922-C931 [PubMed: 11502569]

141. Hiyama TY, Yoshida M, Matsumoto M, Suzuki R, Matsuda T, Watanabe E, Noda M (2013) Endothelin-3 expression in the subfornical organ enhances the sensitivity of $\mathrm{Na}_{\mathrm{X}}$, the brain sodium-level sensor, to suppress salt intake. Cell Metab 17:507-519 [PubMed: 23541371]

142. Ho T, Vessey KA, Fletcher EL (2014) Immunolocalization of the $\mathrm{P} 2 \mathrm{X}_{4}$ receptor on neurons and glia in the mammalian retina. Neuroscience 277:55-71 [PubMed: 24997270]

143. Hofer T, Venance L, Giaume C (2002) Control and plasticity of intercellular calcium waves in astrocytes: a modeling approach. J Neurosci 22:4850-4859 [PubMed: 12077182] 
144. Holtzclaw LA, Pandhit S, Bare DJ, Mignery GA, Russell JT (2002) Astrocytes in adult rat brain express type 2 inositol 1,4,5-trisphosphate receptors. Glia 39:69-84 [PubMed: 12112377]

145. Honsa P, Pivonkova H, Harantova L, Butenko O, Kriska J, Dzamba D, Rusnakova V, Valihrach L, Kubista M, Anderova M (2014) Increased expression of hyperpolarization-activated cyclic nucleotide-gated $(\mathrm{HCN})$ channels in reactive astrocytes following ischemia. Glia 62:2004-2021 [PubMed: 25042871]

146. Horvat A, Zorec R, Vardjan N (2016) Adrenergic stimulation of single rat astrocytes results in distinct temporal changes in intracellular $\mathrm{Ca}^{(2+)}$ and cAMP-dependent PKA responses. Cell Calcium 59:156-163 [PubMed: 26794933]

147. Hosli E, Hosli L (1991) Autoradiographic evidence for endothelin receptors on astrocytes in cultures of rat cerebellum, brainstem and spinal cord. Neurosci Lett 129:55-58 [PubMed: 1656341]

148. Houades V, Koulakoff A, Ezan P, Seif I, Giaume C (2008) Gap junction-mediated astrocytic networks in the mouse barrel cortex. J Neurosci 28:5207-5217 [PubMed: 18480277]

149. Hsuchou H, Pan W, Barnes MJ, Kastin AJ (2009) Leptin receptor mRNA in rat brain astrocytes. Peptides 30:2275-2280 [PubMed: 19747514]

150. Hua X, Malarkey EB, Sunjara V, Rosenwald SE, Li WH, Parpura V (2004) $\mathrm{Ca}^{(2+)}$-dependent glutamate release involves two classes of endoplasmic reticulum $\mathrm{Ca}^{(2+)}$ stores in astrocytes. $\mathrm{J}$ Neurosci Res 76:86-97 [PubMed: 15048932]

151. Huang C, Hu ZL, Wu WN, Yu DF, Xiong QJ, Song JR, Shu Q, Fu H, Wang F, Chen JG (2010) Existence and distinction of acid-evoked currents in rat astrocytes. Glia 58:1415-1424 [PubMed: 20549751]

152. Huang H, Barakat L, Wang D, Bordey A (2004) Bergmann glial GlyT1 mediates glycine uptake and release in mouse cerebellar slices. J Physiol 560:721-736 [PubMed: 15331688]

153. Huang Y, Grinspan JB, Abrams CK, Scherer SS (2007) Pannexin1 is expressed by neurons and glia but does not form functional gap junctions. Glia 55:46-56 [PubMed: 17009242]

154. Hung AC, Sun SH (2002) The $\mathrm{P}_{2} \mathrm{X}_{7}$ receptor-mediated phospholipase D activation is regulated by both PKC-dependent and PKC-independent pathways in a rat brain-derived Type-2 astrocyte cell line, RBA-2. Cell Signal 14:83-92 [PubMed: 11747993]

155. Hutchinson DS, Summers RJ, Gibbs ME (2007) $\beta_{2}$ - and $\beta_{3}$-adrenoceptors activate glucose uptake in chick astrocytes by distinct mechanisms: a mechanism for memory enhancement? J Neurochem 103:997-1008 [PubMed: 17680985]

156. Hwang EM, Kim E, Yarishkin O, Woo DH, Han KS, Park N, Bae Y, Woo J, Kim D, Park M, Lee CJ, Park JY (2014) A disulphide-linked heterodimer of TWIK-1 and TREK-1 mediates passive conductance in astrocytes. Nat Commun 5:3227 [PubMed: 24496152]

157. Iglesias R, Dahl G, Qiu F, Spray DC, Scemes E (2009) Pannexin 1: the molecular substrate of astrocyte "hemichannels". J Neurosci 29:7092-7097 [PubMed: 19474335]

158. Illes P, Verkhratsky A (2016) Purinergic neurone-glia signalling in cognitive-related pathologies. Neuropharmacology 104:62-75 [PubMed: 26256423]

159. Ishii M, Fujita A, Iwai K, Kusaka S, Higashi K, Inanobe A, Hibino H, Kurachi Y (2003) Differential expression and distribution of $\mathrm{K}_{\mathrm{ir}} 5.1$ and $\mathrm{K}_{\mathrm{ir}} 4.1$ inwardly rectifying $\mathrm{K}^{+}$channels in retina. Am J Physiol Cell Physiol 285:C260-C267 [PubMed: 12686518]

160. Ishimoto H, Nakahata N, Matsuoka I, Nakanishi H (1997) Effects of ATP on phosphoinositide hydrolysis and prostaglandin E2 generation in rabbit astrocytes. J Pharm Pharmacol 49:520-524 [PubMed: 9178188]

161. Isokawa M, McKhann GM 2nd (2005) Electrophysiological and morphological characterization of dentate astrocytes in the hippocampus. J Neurobiol 65:125-134 [PubMed: 16114022]

162. Jabs R, Guenther E, Marquordt K, Wheeler-Schilling TH (2000) Evidence for $P 2 X_{3}, P 2 X_{4}, P_{2} X_{5}$ but not for $\mathrm{P}_{2} \mathrm{X}_{7}$ containing purinergic receptors in Muller cells of the rat retina. Brain Res Mol Brain Res 76:205-210 [PubMed: 10762695]

163. Jimenez AI, Castro E, Communi D, Boeynaems JM, Delicado EG, Miras-Portugal MT (2000) Coexpression of several types of metabotropic nucleotide receptors in single cerebellar astrocytes. J Neurochem 75:2071-2079 [PubMed: 11032896] 
164. John GR, Simpson JE, Woodroofe MN, Lee SC, Brosnan CF (2001) Extracellular nucleotides differentially regulate interleukin $-1_{b}$ signaling in primary human astrocytes: implications for inflammatory gene expression. J Neurosci 21:4134-4142 [PubMed: 11404398]

165. Juhaszova M, Blaustein MP (1997) $\mathrm{Na}^{+}$pump low and high ouabain affinity a subunit isoforms are differently distributed in cells. Proc Natl Acad Sci USA 94:1800-1805 [PubMed: 9050859]

166. Juric DM, Mele T, Carman-Krzan M (2011) Involvement of histaminergic receptor mechanisms in the stimulation of NT-3 synthesis in astrocytes. Neuropharmacology 60:1309-1317 [PubMed: 21276809]

167. Jurzak M, Muller AR, Gerstberger R (1995) Characterization of vasopressin receptors in cultured cells derived from the region of rat brain circumventricular organs. Neuroscience 65:1145-1159 [PubMed: 7617168]

168. Kafitz KW, Meier SD, Stephan J, Rose CR (2008) Developmental profile and properties of sulforhodamine 101-Labeled glial cells in acute brain slices of rat hippocampus. J Neurosci Methods 169:84-92 [PubMed: 18187203]

169. Kalsi AS, Greenwood K, Wilkin G, Butt AM (2004) $\mathrm{K}_{\mathrm{ir}} 4.1$ expression by astrocytes and oligodendrocytes in CNS white matter: a developmental study in the rat optic nerve. J Anat 204:475-485 [PubMed: 15198689]

170. Kanaka C, Ohno K, Okabe A, Kuriyama K, Itoh T, Fukuda A, Sato K (2001) The differential expression patterns of messenger RNAs encoding $\mathrm{K}-\mathrm{Cl}$ cotransporters $(\mathrm{KCC} 1,2)$ and $\mathrm{Na}-\mathrm{K}-2 \mathrm{Cl}$ cotransporter (NKCC1) in the rat nervous system. Neuroscience 104:933-946 [PubMed: $11457581]$

171. Kanemaru K, Kubota J, Sekiya H, Hirose K, Okubo Y, Iino M (2013) Calcium-dependent Ncadherin up-regulation mediates reactive astrogliosis and neuroprotection after brain injury. Proc Natl Acad Sci USA 110:11612-11617 [PubMed: 23798419]

172. Kanemaru K, Sekiya H, Xu M, Satoh K, Kitajima N, Yoshida K, Okubo Y, Sasaki T, Moritoh S, Hasuwa H, Mimura M, Horikawa K, Matsui K, Nagai T, Iino M, Tanaka KF (2014) In vivo visualization of subtle, transient, and local activity of astrocytes using an ultrasensitive $\mathrm{Ca}^{(2+)}$ indicator. Cell Rep 8:311-318 [PubMed: 24981861]

173. Kanjhan R, Housley GD, Thorne PR, Christie DL, Palmer DJ, Luo L, Ryan AF (1996) Localization of ATP-gated ion channels in cerebellum using $\mathrm{P} 2 \times 2 \mathrm{R}$ subunit-specific antisera. NeuroReport 7:2665-2669 [PubMed: 8981443]

174. Karschin A, Brockhaus J, Ballanyi K (1998) KATP channel formation by the sulphonylurea receptors SUR1 with $\mathrm{K}_{\mathrm{ir}} 6.2$ subunits in rat dorsal vagal neurons in situ. J Physiol 509(Pt 2):339346 [PubMed: 9575284]

175. Kastritsis CH, Salm AK, McCarthy K (1992) Stimulation of the P2Y purinergic receptor on type 1 astroglia results in inositol phosphate formation and calcium mobilization. J Neurochem 58:1277-1284 [PubMed: 1548464]

176. Kato S, Ishita S, Sugawara K, Mawatari K (1993) Cystine/glutamate antiporter expression in retinal Muller glial cells: implications for DL-alpha-aminoadipate toxicity. Neuroscience 57:473482 [PubMed: 7906874]

177. Kavanaugh MP, Arriza JL, North RA, Amara SG (1992) Electrogenic uptake of $\gamma$-aminobutyric acid by a cloned transporter expressed in Xenopus oocytes. J Biol Chem 267:22007-22009 [PubMed: 1429551]

178. Kelly T, Kafitz KW, Roderigo C, Rose CR (2009) Ammonium-evoked alterations in intracellular sodium and $\mathrm{pH}$ reduce glial glutamate transport activity. Glia 57:921-934 [PubMed: 19053055]

179. Kettenmann H, Backus KH, Schachner M (1984) Aspartate, glutamate and gamma-aminobutyric acid depolarize cultured astrocytes. Neurosci Lett 52:25-29 [PubMed: 6152041]

180. Kettenmann H, Backus KH, Schachner M (1987) $\gamma$-Aminobutyric acid opens $\mathrm{Cl}^{-}$channels in cultured astrocytes. Brain Res 404:1-9 [PubMed: 2436707]

181. Kettenmann H, Ransom BR (1988) Electrical coupling between astrocytes and between oligodendrocytes studied in mammalian cell cultures. Glia 1:64-73 [PubMed: 2853139]

182. Kettenmann H, Schachner M (1985) Pharmacological properties of gamma-aminobutyric acid-, glutamate-, and aspartate-induced depolarizations in cultured astrocytes. J Neurosci 5:3295-3301 [PubMed: 2867131] 
183. Kettenmann H, Zorec R (2013) Release of gliotransmitters and transmitter receptors in astrocytes In: Kettenmann H, Ransom BR (eds) Neuroglia. Oxford University Press, New York, pp 197-211

184. Khan ZU, Koulen P, Rubinstein M, Grandy DK, Goldman-Rakic PS (2001) An astroglialinked dopamine $\mathrm{D}_{2}$-receptor action in prefrontal cortex. Proc Natl Acad Sci USA 98:1964-1969 [PubMed: 11172059]

185. Kim WT, Rioult MG, Cornell-Bell AH (1994) Glutamate-induced calcium signaling in astrocytes. Glia 11:173-184 [PubMed: 7927645]

186. Kimelberg HK, Macvicar BA, Sontheimer H (2006) Anion channels in astrocytes: biophysics, pharmacology, and function. Glia 54:747-757 [PubMed: 17006903]

187. King AE, Ackley MA, Cass CE, Young JD, Baldwin SA (2006) Nucleoside transporters: from scavengers to novel therapeutic targets. Trends Pharmacol Sci 27:416-425 [PubMed: 16820221]

188. Kirchhoff F, Mulhardt C, Pastor A, Becker CM, Kettenmann H (1996) Expression of glycine receptor subunits in glial cells of the rat spinal cord. J Neurochem 66:1383-1390 [PubMed: 8627289]

189. Kirischuk S, Kettenmann H, Verkhratsky A (1997) $\mathrm{Na}^{+} / \mathrm{Ca}^{2+}$ exchanger modulates kainatetriggered $\mathrm{Ca}^{2+}$ signaling in Bergmann glial cells in situ. FASEB J 11:566-572 [PubMed: 9212080]

190. Kirischuk S, Kettenmann H, Verkhratsky A (2007) Membrane currents and cytoplasmic sodium transients generated by glutamate transport in Bergmann glial cells. Pflugers Arch 454:245-252 [PubMed: 17273865]

191. Kirischuk S, Kirchhoff F, Matyash V, Kettenmann H, Verkhratsky A (1999) Glutamatetriggered calcium signalling in mouse bergmann glial cells in situ: role of inositol-1,4,5-trisphosphatemediated intracellular calcium release. Neuroscience 92:1051-1059 [PubMed: 10426545]

192. Kirischuk S, Parpura V, Verkhratsky A (2012) Sodium dynamics: another key to astroglial excitability? Trends Neurosci 35:497-506 [PubMed: 22633141]

193. Kirischuk S, Tuschick S, Verkhratsky A, Kettenmann H (1996) Calcium signalling in mouse Bergmann glial cells mediated by $\mathrm{a}_{1}$-adrenoreceptors and $\mathrm{H}_{1}$ histamine receptors. Eur $\mathbf{J}$ Neurosci 8:1198-1208 [PubMed: 8752590]

194. Kofuji P, Biedermann B, Siddharthan V, Raap M, Iandiev I, Milenkovic I, Thomzig A, Veh RW, Bringmann A, Reichenbach A (2002) $\mathrm{K}_{\text {ir }}$ potassium channel subunit expression in retinal glial cells: implications for spatial potassium buffering. Glia 39:292-303 [PubMed: 12203395]

195. von Kölliker A (1896) Handbuch der Gewebelehre des Menschen, 6 Aufl. Engelmann, Leipzig

196. Kong EK, Peng L, Chen Y, Yu AC, Hertz L (2002) Up-regulation of 5-HT2B receptor density and receptor-mediated glycogenolysis in mouse astrocytes by long-term fluoxetine administration. Neurochem Res 27:113-120 [PubMed: 11930908]

197. Kukley M, Barden JA, Steinhauser C, Jabs R (2001) Distribution of P2X receptors on astrocytes in juvenile rat hippocampus. Glia 36:11-21 [PubMed: 11571780]

198. Kunzelmann P, Schroder W, Traub O, Steinhauser C, Dermietzel R, Willecke K (1999) Late onset and increasing expression of the gap junction protein connexin 30 in adult murine brain and longterm cultured astrocytes. Glia 25:111-119 [PubMed: 9890626]

199. Kuo J, Hariri OR, Micevych P (2009) An interaction of oxytocin receptors with metabotropic glutamate receptors in hypothalamic astrocytes. J Neuroendocrinol 21:1001-1006 [PubMed: 19807846]

200. Lalo U, Palygin O, North RA, Verkhratsky A, Pankratov Y (2011) Age-dependent remodelling of ionotropic signalling in cortical astroglia. Aging Cell 10:392-402 [PubMed: 21272193]

201. Lalo U, Palygin O, Rasooli-Nejad S, Andrew J, Haydon PG, Pankratov Y (2014) Exocytosis of ATP from astrocytes modulates phasic and tonic inhibition in the neocortex. PLoS Biol 12:e1001747 [PubMed: 24409095]

202. Lalo U, Pankratov Y, Kirchhoff F, North RA, Verkhratsky A (2006) NMDA receptors mediate neuron-to-glia signaling in mouse cortical astrocytes. J Neurosci 26:2673-2683 [PubMed: 16525046]

203. Lalo U, Pankratov Y, Parpura V, Verkhratsky A (2011) Ionotropic receptors in neuronalastroglial signalling: what is the role of "excitable" molecules in non-excitable cells. Biochim Biophys Acta 1813:992-1002 [PubMed: 20869992] 
204. Lalo U, Pankratov Y, Wichert SP, Rossner MJ, North RA, Kirchhoff F, Verkhratsky A (2008) $\mathrm{P} 2 \mathrm{X}_{1}$ and $\mathrm{P} 2 \mathrm{X}_{5}$ subunits form the functional $\mathrm{P} 2 \mathrm{X}$ receptor in mouse cortical astrocytes. $\mathrm{J}$ Neurosci 28:5473-5480 [PubMed: 18495881]

205. Langer J, Rose CR (2009) Synaptically induced sodium signals in hippocampal astrocytes in situ. J Physiol 587:5859-5877 [PubMed: 19858225]

206. Langer J, Stephan J, Theis M, Rose CR (2012) Gap junctions mediate intercellular spread of sodium between hippocampal astrocytes in situ. Glia 60:239-252 [PubMed: 22025386]

207. Larsen BR, Assentoft M, Cotrina ML, Hua SZ, Nedergaard M, Kaila K, Voipio J, MacAulay N (2014) Contributions of the $\mathrm{Na}^{+} / \mathrm{K}^{+}$-ATPase, NKCC1, and $\mathrm{K}_{\mathrm{ir}} 4.1$ to hippocampal $\mathrm{K}^{+}$clearance and volume responses. Glia 62:608-622 [PubMed: 24482245]

208. Latour I, Gee CE, Robitaille R, Lacaille JC (2001) Differential mechanisms of $\mathrm{Ca}^{2+}$ responses in glial cells evoked by exogenous and endogenous glutamate in rat hippocampus. Hippocampus 11:132-145 [PubMed: 11345120]

209. Latour I, Hamid J, Beedle AM, Zamponi GW, Macvicar BA (2003) Expression of voltage-gated $\mathrm{Ca}^{2+}$ channel subtypes in cultured astrocytes. Glia 41:347-353 [PubMed: 12555202]

210. Lee MC, Ting KK, Adams S, Brew BJ, Chung R, Guillemin GJ (2010) Characterisation of the expression of NMDA receptors in human astrocytes. PLoS ONE 5:e14123 [PubMed: 21152063]

211. Lee SM, Cho YS, Kim TH, Jin MU, Ahn DK, Noguchi K, Bae YC (2012) An ultrastructural evidence for the expression of transient receptor potential ankyrin 1 (TRPA1) in astrocytes in the rat trigeminal caudal nucleus. J Chem Neuroanat 45:45-49 [PubMed: 22813698]

212. Lehre KP, Danbolt NC (1998) The number of glutamate transporter subtype molecules at glutamatergic synapses: chemical and stereological quantification in young adult rat brain. $\mathrm{J}$ Neurosci 18:8751-8757 [PubMed: 9786982]

213. von Lenhossék M (1895) Der feinere Bau des Nervensystems im Lichte neuester Forschung, 2nd edn Fischer's Medicinische Buchhandlung H. Kornfield, Berlin

214. Leonoudakis D, Mailliard W, Wingerd K, Clegg D, Vandenberg C (2001) Inward rectifier potassium channel $\mathrm{K}_{\mathrm{ir}} 2.2$ is associated with synapse-associated protein SAP97. J Cell Sci 114:987-998 [PubMed: 11181181]

215. Letellier M, Park YK, Chater TE, Chipman PH, Gautam SG, Oshima-Takago T, Goda Y (2016) Astrocytes regulate heterogeneity of presynaptic strengths in hippocampal networks. Proc Natl Acad Sci USA 113:E2685-E2694 [PubMed: 27118849]

216. Leybaert L, Sanderson MJ (2001) Intercellular calcium signaling and flash photolysis of caged compounds. A sensitive method to evaluate gap junctional coupling. Methods Mol Biol 154:407430 [PubMed: 11218662]

217. Li B, Gu L, Hertz L, Peng L (2013) Expression of nucleoside transporter in freshly isolated neurons and astrocytes from mouse brain. Neurochem Res 38:2351-2358 [PubMed: 24026568]

218. Liang J, Chao D, Sandhu HK, Yu Y, Zhang L, Balboni G, Kim DH, Xia Y (2014) $\delta$-Opioid receptors up-regulate excitatory amino acid transporters in mouse astrocytes. Br J Pharmacol 171:5417-5430 [PubMed: 25052197]

219. Lisjak M, Potokar M, Rituper B, Jorgacevski J, Zorec R (2017) AQP4e-based orthogonal arrays regulate rapid cell volume changes in astrocytes. J Neurosci 37:10748-10756 [PubMed: 28978666]

220. Liu X, Bandyopadhyay BC, Nakamoto T, Singh B, Liedtke W, Melvin JE, Ambudkar I (2006) A role for AQP5 in activation of TRPV4 by hypotonicity: concerted involvement of AQP5 and TRPV4 in regulation of cell volume recovery. J Biol Chem 281:15485-15495 [PubMed: 16571723]

221. Loesch A, Burnstock G (1998) Electron-immunocytochemical localization of $\mathrm{P} 2 \mathrm{X}_{1}$ receptors in the rat cerebellum. Cell Tissue Res 294:253-260 [PubMed: 9799441]

222. Longden TA, Dunn KM, Draheim HJ, Nelson MT, Weston AH, Edwards G (2011) Intermediateconductance calcium-activated potassium channels participate in neurovascular coupling. $\mathrm{Br} \mathrm{J}$ Pharmacol 164:922-933 [PubMed: 21506954]

223. Lu CC, Hilgemann DW (1999) GAT1 (GABA: $\mathrm{Na}^{+}: \mathrm{Cl}^{-}$) cotransport function. Steady state studies in giant Xenopus oocyte membrane patches. J Gen Physiol 114:429-444 [PubMed: 10469733] 
224. Lu DC, Zhang H, Zador Z, Verkman AS (2008) Impaired olfaction in mice lacking aquaporin-4 water channels. FASEB J 22:3216-3223 [PubMed: 18511552]

225. Lu Z (2004) Mechanism of rectification in inward-rectifier $\mathrm{K}^{+}$channels. Annu Rev Physiol 66:103-129 [PubMed: 14977398]

226. Macaulay N, Zeuthen $\mathrm{T}$ (2012) Glial $\mathrm{K}^{+}$clearance and cell swelling: key roles for cotransporters and pumps. Neurochem Res 37:2299-2309 [PubMed: 22367475]

227. MacVicar BA, Feighan D, Brown A, Ransom B (2002) Intrinsic optical signals in the rat optic nerve: role for $\mathrm{K}^{+}$uptake via NKCC1 and swelling of astrocytes. Glia 37:114-123 [PubMed: 11754210]

228. MacVicar BA, Tse FW (1988) Norepinephrine and cyclic adenosine $3^{\prime}: 5^{\prime}$-cyclic monophosphate enhance a nifedipine-sensitive calcium current in cultured rat astrocytes. Glia 1:359-365 [PubMed: 2852639]

229. MacVicar BA, Tse FW, Crichton SA, Kettenmann H (1989) GABA-activated $\mathrm{Cl}^{-}$channels in astrocytes of hippocampal slices. J Neurosci 9:3577-3583 [PubMed: 2477511]

230. Magnotti LM, Goodenough DA, Paul DL (2011) Functional heterotypic interactions between astrocyte and oligodendrocyte connexins. Glia 59:26-34 [PubMed: 21046554]

231. Malarkey EB, Ni Y, Parpura V (2008) $\mathrm{Ca}^{2+}$ entry through TRPC1 channels contributes to intracellular $\mathrm{Ca}^{2+}$ dynamics and consequent glutamate release from rat astrocytes. Glia 56:821835 [PubMed: 18338793]

232. Mantyh PW, Rogers SD, Allen CJ, Catton MD, Ghilardi JR, Levin LA, Maggio JE, Vigna SR (1995) $\beta_{2}$-adrenergic receptors are expressed by glia in vivo in the normal and injured central nervous system in the rat, rabbit, and human. J Neurosci 15:152-164 [PubMed: 7823126]

233. Marsault R, Vigne P, Breittmayer JP, Frelin C (1990) Astrocytes are target cells for endothelins and sarafotoxin. J Neurochem 54:2142-2144 [PubMed: 2187055]

234. Martineau M, Parpura V, Mothet JP (2014) Cell-type specific mechanisms of D-serine uptake and release in the brain. Front Synaptic Neurosci 6:12 [PubMed: 24910611]

235. Maucler C, Pernot P, Vasylieva N, Pollegioni L, Marinesco S (2013) In vivo D-serine heteroexchange through alanine-serine-cysteine (ASC) transporters detected by microelectrode biosensors. ACS Chem Neurosci. 4:772-781 [PubMed: 23581544]

236. McCarthy KD, Salm AK (1991) Pharmacologically-distinct subsets of astroglia can be identified by their calcium response to neuroligands. Neuroscience 41:325-333 [PubMed: 1678498]

237. Miller RL, Loewy AD (2013) ENaC $\boldsymbol{\gamma}$-expressing astrocytes in the circumventricular organs, white matter, and ventral medullary surface: sites for $\mathrm{Na}^{+}$regulation by glial cells. J Chem Neuroanat 53:72-80 [PubMed: 24145067]

238. Miller RL, Wang MH, Gray PA, Salkoff LB, Loewy AD (2013) ENaC-expressing neurons in the sensory circumventricular organs become c-Fos activated following systemic sodium changes. Am J Physiol Regul Integr Comp Physiol 305:R1141-R1152 [PubMed: 24049115]

239. Milner TA, Lee A, Aicher SA, Rosin DL (1998) Hippocampal $a_{2 a}$-adrenergic receptors are located predominantly presynaptically but are also found postsynaptically and in selective astrocytes. J Comp Neurol 395:310-327 [PubMed: 9596526]

240. Minelli A, Castaldo P, Gobbi P, Salucci S, Magi S, Amoroso S (2007) Cellular and subcellular localization of $\mathrm{Na}^{+}-\mathrm{Ca}^{2+}$ exchanger protein isoforms, $\mathrm{NCX} 1, \mathrm{NCX} 2$, and $\mathrm{NCX} 3$ in cerebral cortex and hippocampus of adult rat. Cell Calcium 41:221-234 [PubMed: 16914199]

241. Minelli A, DeBiasi S, Brecha NC, Zuccarello LV, Conti F (1996) GAT-3, a high-affinity GABA plasma membrane transporter, is localized to astrocytic processes, and it is not confined to the vicinity of GABAergic synapses in the cerebral cortex. J Neurosci 16:6255-6264 [PubMed: 8815906]

242. Mishima T, Hirase H (2010) In vivo intracellular recording suggests that gray matter astrocytes in mature cerebral cortex and hippocampus are electrophysiologically homogeneous. J Neurosci 30:3093-3100 [PubMed: 20181606]

243. Mishima T, Sakatani S, Hirase H (2007) Intracellular labeling of single cortical astrocytes in vivo. J Neurosci Methods 166:32-40 [PubMed: 17686526] 
244. Miyano K, Morioka N, Sugimoto T, Shiraishi S, Uezono Y, Nakata Y (2010) Activation of the neurokinin-1 receptor in rat spinal astrocytes induces $\mathrm{Ca}^{2+}$ release from $\mathrm{IP}_{3}$-sensitive $\mathrm{Ca}^{2+}$ stores and extracellular $\mathrm{Ca}^{2+}$ influx through TRPC3. Neurochem Int 57:923-934 [PubMed: 20933035]

245. Miyazaki I, Asanuma M, Diaz-Corrales FJ, Miyoshi K, Ogawa N (2004) Direct evidence for expression of dopamine receptors in astrocytes from basal ganglia. Brain Res 1029:120-123 [PubMed: 15533323]

246. Molnar T, Yarishkin O, Iuso A, Barabas P, Jones B, Marc RE, Phuong TT, Krizaj D (2016) Storeoperated calcium entry in muller glia is controlled by synergistic activation of TRPC and Orai channels. J Neurosci 36:3184-3198 [PubMed: 26985029]

247. Monai H, Ohkura M, Tanaka M, Oe Y, Konno A, Hirai H, Mikoshiba K, Itohara S, Nakai J, Iwai Y, Hirase H (2016) Calcium imaging reveals glial involvement in transcranial direct current stimulation-induced plasticity in mouse brain. Nat Commun 7:11100 [PubMed: 27000523]

248. Moreno C, Sampieri A, Vivas O, Pena-Segura C, Vaca L (2012) STIM1 and Orai1 mediate thrombin-induced $\mathrm{Ca}^{2+}$ influx in rat cortical astrocytes. Cell Calcium 52:457-467 [PubMed: 22944608]

249. Morgello S, Uson RR, Schwartz EJ, Haber RS (1995) The human blood-brain barrier glucose transporter (GLUT1) is a glucose transporter of gray matter astrocytes. Glia 14:43-54 [PubMed: 7615345]

250. Muhic M, Vardjan N, Chowdhury HH, Zorec R, Kreft M (2015) Insulin and insulin-like growth factor 1 (IGF-1) modulate cytoplasmic glucose and glycogen levels but not glucose transport across the membrane in astrocytes. J Biol Chem 290:11167-11176 [PubMed: 25792745]

251. Mulkey DK, Wenker IC (2011) Astrocyte chemoreceptors: mechanisms of $\mathrm{H}^{+}$sensing by astrocytes in the retrotrapezoid nucleus and their possible contribution to respiratory drive. Exp Physiol 96:400-406 [PubMed: 21169332]

252. Muller T, Fritschy JM, Grosche J, Pratt GD, Mohler H, Kettenmann H (1994) Developmental regulation of voltage-gated $\mathrm{K}^{+}$channel and GABAA receptor expression in Bergmann glial cells. J Neurosci 14:2503-2514 [PubMed: 8182424]

253. Muller T, Moller T, Berger T, Schnitzer J, Kettenmann H (1992) Calcium entry through kainate receptors and resulting potassium-channel blockade in Bergmann glial cells. Science 256:15631566 [PubMed: 1317969]

254. Murphy S, Welk G (1990) Hydrolysis of polyphosphoinositides in astrocytes by plateletactivating factor. Eur J Pharmacol 188:399-401 [PubMed: 2164941]

255. Nadarajah B, Thomaidou D, Evans WH, Parnavelas JG (1996) Gap junctions in the adult cerebral cortex: regional differences in their distribution and cellular expression of connexins. J Comp Neurol 376:326-342 [PubMed: 8951647]

256. Nagelhus EA, Ottersen OP (2013) Physiological roles of aquaporin-4 in brain. Physiol Rev 93:1543-1562 [PubMed: 24137016]

257. Nagy JI, Dudek FE, Rash JE (2004) Update on connexins and gap junctions in neurons and glia in the mammalian nervous system. Brain Res Brain Res Rev 47:191-215 [PubMed: 15572172]

258. Nagy JI, Li X, Rempel J, Stelmack G, Patel D, Staines WA, Yasumura T, Rash JE (2001) Connexin 26 in adult rodent central nervous system: demonstration at astrocytic gap junctions and colocalization with connexin30 and connexin43. J Comp Neurol 441:302-323 [PubMed: 11745652]

259. Nagy JI, Lynn BD, Tress O, Willecke K, Rash JE (2011) Connexin26 expression in brain parenchymal cells demonstrated by targeted connexin ablation in transgenic mice. Eur J Neurosci 34:263-271 [PubMed: 21714813]

260. Narcisse L, Scemes E, Zhao Y, Lee SC, Brosnan CF (2005) The cytokine IL-1 $\beta$ transiently enhances $\mathrm{P} 2 \mathrm{X}_{7}$ receptor expression and function in human astrocytes. Glia. 49:245-258 [PubMed: 15472991]

261. Navarrete M, Araque A (2008) Endocannabinoids mediate neuron-astrocyte communication. Neuron 57:883-893 [PubMed: 18367089]

262. Navarrete M, Araque A (2010) Endocannabinoids potentiate synaptic transmission through stimulation of astrocytes. Neuron 68:113-126 [PubMed: 20920795] 
263. Newman EA (1996) Acid efflux from retinal glial cells generated by sodium bicarbonate cotransport. J Neurosci 16:159-168 [PubMed: 8613782]

264. Nilsson M, Eriksson PS, Ronnback L, Hansson E (1993) GABA induces $\mathrm{Ca}^{2+}$ transients in astrocytes. Neuroscience 54:605-614 [PubMed: 8332251]

265. Nilsson M, Hansson E, Ronnback L (1991) Adrenergic and 5-HT2 receptors on the same astroglial cell. A microspectrofluorimetric study on cytosolic $\mathrm{Ca}^{2+}$ responses in single cells in primary culture. Brain Res Dev Brain Res 63:33-41 [PubMed: 1790597]

266. Nobile M, Monaldi I, Alloisio S, Cugnoli C, Ferroni S (2003) ATP-induced, sustained calcium signalling in cultured rat cortical astrocytes: evidence for a non-capacitative, P2X7-likemediated calcium entry. FEBS Lett 538:71-76 [PubMed: 12633855]

267. Noda M, Sakuta H (2013) Central regulation of body-fluid homeostasis. Trends Neurosci 36:661673 [PubMed: 24016361]

268. Norenberg W, Schunk J, Fischer W, Sobottka H, Riedel T, Oliveira JF, Franke H, Illes P (2010) Electrophysiological classification of $\mathrm{P}_{2} \mathrm{X}_{7}$ receptors in rat cultured neocortical astroglia. $\mathrm{Br} \mathrm{J}$ Pharmacol 160:1941-1952 [PubMed: 20649592]

269. Nwaobi SE, Cuddapah VA, Patterson KC, Randolph AC, Olsen ML (2016) The role of glialspecific $\mathrm{K}_{\mathrm{ir}} 4.1$ in normal and pathological states of the CNS. Acta Neuropathol 132:1-21 [PubMed: 26961251]

270. O'Connor ER, Sontheimer H, Ransom BR (1994) Rat hippocampal astrocytes exhibit electrogenic sodium-bicarbonate co-transport. J Neurophysiol 72:2580-2589 [PubMed: 7897475]

271. Oikawa H, Nakamichi N, Kambe Y, Ogura M, Yoneda Y (2005) An increase in intracellular free calcium ions by nicotinic acetylcholine receptors in a single cultured rat cortical astrocyte. $\mathrm{J}$ Neurosci Res 79:535-544 [PubMed: 15635597]

272. Oliveira JF, Riedel T, Leichsenring A, Heine C, Franke H, Krugel U, Norenberg W, Illes P (2011) Rodent cortical astroglia express in situ functional $\mathrm{P} 2 \mathrm{X}_{7}$ receptors sensing pathologically high ATP concentrations. Cereb Cortex 21:806-820 [PubMed: 20739479]

273. Olsen ML, Campbell SL, Sontheimer H (2007) Differential distribution of $\mathrm{K}_{\mathrm{ir}} 4.1$ in spinal cord astrocytes suggests regional differences in $\mathrm{K}^{+}$homeostasis. J Neurophysiol 98:786-793 [PubMed: 17581847]

274. Orellana JA, Saez PJ, Cortes-Campos C, Elizondo RJ, Shoji KF, Contreras-Duarte S, Figueroa V, Velarde V, Jiang JX, Nualart F, Saez JC, Garcia MA (2012) Glucose increases intracellular free $\mathrm{Ca}^{2+}$ in tanycytes via ATP released through connexin 43 hemichannels. Glia 60:53-68 [PubMed: 21987367]

275. Orellana JA, Saez PJ, Shoji KF, Schalper KA, Palacios-Prado N, Velarde V, Giaume C, Bennett MV, Saez JC (2009) Modulation of brain hemichannels and gap junction channels by proinflammatory agents and their possible role in neurodegeneration. Antioxid Redox Signal 11:369-399 [PubMed: 18816186]

276. Orlowski J, Grinstein S (1997) $\mathrm{Na}^{+} / \mathrm{H}^{+}$exchangers of mammalian cells. J Biol Chem 272:2237322376 [PubMed: 9278382]

277. Orthmann-Murphy JL, Freidin M, Fischer E, Scherer SS, Abrams CK (2007) Two distinct heterotypic channels mediate gap junction coupling between astrocyte and oligodendrocyte connexins. J Neurosci 27:13949-13957 [PubMed: 18094232]

278. Owe SG, Marcaggi P, Attwell D (2006) The ionic stoichiometry of the GLAST glutamate transporter in salamander retinal glia. J Physiol 577:591-599 [PubMed: 17008380]

279. Pakhotin P, Verkhratsky A (2005) Electrical synapses between Bergmann glial cells and Purkinje neurones in rat cerebellar slices. Mol Cell Neurosci 28:79-84 [PubMed: 15607943]

280. Palygin O, Lalo U, Pankratov Y (2011) Distinct pharmacological and functional properties of NMDA receptors in mouse cortical astrocytes. Br J Pharmacol 163:1755-1766 [PubMed: 21449975]

281. Palygin O, Lalo U, Verkhratsky A, Pankratov Y (2010) Ionotropic NMDA and P2X $1 / 5$ receptors mediate synaptically induced $\mathrm{Ca}^{2+}$ signalling in cortical astrocytes. Cell Calcium 48:225-231 [PubMed: 20926134]

282. Panenka W, Jijon H, Herx LM, Armstrong JN, Feighan D, Wei T, Yong VW, Ransohoff RM, MacVicar BA (2001) P2X 7 -like receptor activation in astrocytes increases chemokine monocyte 
chemoattractant protein-1 expression via mitogen-activated protein kinase. J Neurosci 21:71357142 [PubMed: 11549724]

283. Pangrsic T, Potokar M, Haydon PG, Zorec R, Kreft M (2006) Astrocyte swelling leads to membrane unfolding, not membrane insertion. J Neurochem 99:514-523 [PubMed: 17029603]

284. Pankratov Y, Lalo U (2015) Role for astroglial a 1-adrenoreceptors in gliotransmission and control of synaptic plasticity in the neocortex. Front Cell Neurosci 9:230 [PubMed: 26136663]

285. Pappalardo LW, Black JA, Waxman SG (2016) Sodium channels in astroglia and microglia. Glia

286. Pappalardo LW, Liu S, Black JA, Waxman SG (2014) Dynamics of sodium channel $\mathrm{Na}_{\mathrm{V}} 1.5$ expression in astrocytes in mouse models of multiple sclerosis. NeuroReport 25:1208-1215 [PubMed: 25144393]

287. Pappalardo LW, Samad OA, Black JA, Waxman SG (2014) Voltage-gated sodium channel $\mathrm{Na}_{\mathrm{V}} 1.5$ contributes to astrogliosis in an in vitro model of glial injury via reverse $\mathrm{Na}^{+} / \mathrm{Ca}^{2+}$ exchange. Glia 62:1162-1175 [PubMed: 24740847]

288. Pappas CA, Ransom BR (1993) A depolarization-stimulated, bafilomycin-inhibitable $\mathrm{H}^{+}$pump in hippocampal astrocytes. Glia 9:280-291 [PubMed: 8112821]

289. Parekh AB, Putney JW Jr (2005) Store-operated calcium channels. Physiol Rev 85:757-810 [PubMed: 15788710]

290. Park H, Han KS, Oh SJ, Jo S, Woo J, Yoon BE, Lee CJ (2013) High glutamate permeability and distal localization of Best1 channel in CA1 hippocampal astrocyte. Mol Brain 6:54 [PubMed: 24321245]

291. Parkerson KA, Sontheimer H (2004) Biophysical and pharmacological characterization of hypotonically activated chloride currents in cortical astrocytes. Glia 46:419-436 [PubMed: 15095372]

292. Parpura V, Basarsky TA, Liu F, Jeftinija K, Jeftinija S, Haydon PG (1994) Glutamate-mediated astrocyte-neuron signalling. Nature 369:744-747 [PubMed: 7911978]

293. Parpura V, Scemes E, Spray DC (2004) Mechanisms of glutamate release from astrocytes: gap junction "hemichannels", purinergic receptors and exocytotic release. Neurochem Int 45:259-264 [PubMed: 15145541]

294. Parri HR, Gould TM, Crunelli V (2001) Spontaneous astrocytic $\mathrm{Ca}^{2+}$ oscillations in situ drive NMDAR-mediated neuronal excitation. Nat Neurosci 4:803-812 [PubMed: 11477426]

295. Pastor A, Chvatal A, Sykova E, Kettenmann H (1995) Glycine- and GABA-activated currents in identified glial cells of the developing rat spinal cord slice. Eur J Neurosci 7:1188-1198 [PubMed: 7582092]

296. Pastor A, Kremer M, Moller T, Kettenmann H, Dermietzel R (1998) Dye coupling between spinal cord oligodendrocytes: differences in coupling efficiency between gray and white matter. Glia 24:108-120 [PubMed: 9700494]

297. Peakman MC, Hill SJ (1995) Adenosine $A_{1}$ receptor-mediated changes in basal and histaminestimulated levels of intracellular calcium in primary rat astrocytes. Br J Pharmacol 115:801-810 [PubMed: 8548180]

298. Pearce B, Langley D (1994) Purine- and pyrimidine-stimulated phosphoinositide breakdown and intracellular calcium mobilisation in astrocytes. Brain Res 660:329-332 [PubMed: 7820701]

299. Pearce B, Murphy S, Jeremy J, Morrow C, Dandona P (1989) ATP-evoked Ca ${ }^{2+}$ mobilisation and prostanoid release from astrocytes: P2-purinergic receptors linked to phosphoinositide hydrolysis. J Neurochem 52:971-977 [PubMed: 2918318]

300. Peng L, Huang R, Yu AC, Fung KY, Rathbone MP, Hertz L (2005) Nucleoside transporter expression and function in cultured mouse astrocytes. Glia 52:25-35 [PubMed: 15892125]

301. Pereira GJ, Hirata H, Fimia GM, do Carmo LG, Bincoletto C, Han SW, Stilhano RS, Ureshino RP, Bloor-Young D, Churchill G, Piacentini M, Patel S, Smaili SS (2011) Nicotinic acid adenine dinucleotide phosphate (NAADP) regulates autophagy in cultured astrocytes. J Biol Chem 286:27875-27881 [PubMed: 21610076]

302. Petravicz J, Boyt KM, McCarthy KD (2014) Astrocyte $\mathrm{IP}_{3} \mathrm{R} 2$-dependent $\mathrm{Ca}^{2+}$ signaling is not a major modulator of neuronal pathways governing behavior. Front Behav Neurosci 8:384 [PubMed: 25429263] 
303. Petravicz J, Fiacco TA, McCarthy KD (2008) Loss of $\mathrm{IP}_{3}$ receptor-dependent $\mathrm{Ca}^{2+}$ increases in hippocampal astrocytes does not affect baseline CA1 pyramidal neuron synaptic activity. J Neurosci 28:4967-4973 [PubMed: 18463250]

304. Petroni A, Salami M, Blasevich M, Papini N, Galella G, Colombo C, Galli C (1994) Eicosanoid and inositol phosphate response to platelet-activating factor (PAF) and to a PAF antagonist in rat astroglial cells. Brain Res Dev Brain Res 78:169-174 [PubMed: 8026072]

305. Philippe JM, Dubois JM, Rouzaire-Dubois B, Cartron PF, Vallette F, Morel N (2002) Functional expression of V-ATPases in the plasma membrane of glial cells. Glia 37:365-373 [PubMed: 11870875]

306. Pilitsis JG, Kimelberg HK (1998) Adenosine receptor mediated stimulation of intracellular calcium in acutely isolated astrocytes. Brain Res 798:294-303 [PubMed: 9666151]

307. Pines G, Danbolt NC, Bjoras M, Zhang Y, Bendahan A, Eide L, Koepsell H, Storm-Mathisen J, Seeberg E, Kanner BI (1992) Cloning and expression of a rat brain L-glutamate transporter. Nature 360:464-467 [PubMed: 1448170]

308. Pizzo P, Burgo A, Pozzan T, Fasolato C (2001) Role of capacitative calcium entry on glutamateinduced calcium influx in type-I rat cortical astrocytes. J Neurochem 79:98-109 [PubMed: 11595762]

309. Poopalasundaram S, Knott C, Shamotienko OG, Foran PG, Dolly JO, Ghiani CA, Gallo V, Wilkin GP (2000) Glial heterogeneity in expression of the inwardly rectifying $\mathrm{K}^{+}$channel, $\mathrm{K}_{\mathrm{ir}} 4.1$, in adult rat CNS. Glia. 30:362-372 [PubMed: 10797616]

310. Porter JT, McCarthy KD (1995) Adenosine receptors modulate $\left[\mathrm{Ca}^{2+}\right]_{\mathrm{i}}$ in hippocampal astrocytes in situ. J Neurochem 65:1515-1523 [PubMed: 7561845]

311. Porter JT, McCarthy KD (1995) GFAP-positive hippocampal astrocytes in situ respond to glutamatergic neuroligands with increases in $\left[\mathrm{Ca}^{2+}\right.$ ]i. Glia. 13:101-112 [PubMed: 7544323]

312. Porter JT, McCarthy KD (1996) Hippocampal astrocytes in situ respond to glutamate released from synaptic terminals. J Neurosci 16:5073-5081 [PubMed: 8756437]

313. Potokar M, Stenovec M, Jorgacevski J, Holen T, Kreft M, Ottersen OP, Zorec R (2013) Regulation of AQP4 surface expression via vesicle mobility in astrocytes. Glia 61:917-928 [PubMed: 23505074]

314. Potter LR, Abbey-Hosch S, Dickey DM (2006) Natriuretic peptides, their receptors, and cyclic guanosine monophosphate-dependent signaling functions. Endocr Rev 27:47-72 [PubMed: 16291870]

315. Price DL, Ludwig JW, Mi H, Schwarz TL, Ellisman MH (2002) Distribution of rSlo Ca ${ }^{2+}$ activated $\mathrm{K}^{+}$channels in rat astrocyte perivascular endfeet. Brain Res 956:183-193 [PubMed: 12445685]

316. Price TJ, Hargreaves KM, Cervero F (2006) Protein expression and mRNA cellular distribution of the NKCC1 cotransporter in the dorsal root and trigeminal ganglia of the rat. Brain Res 1112:146-158 [PubMed: 16904086]

317. Raap M, Biedermann B, Braun P, Milenkovic I, Skatchkov SN, Bringmann A, Reichenbach A (2002) Diversity of $\mathrm{K}_{\mathrm{ir}}$ channel subunit mRNA expressed by retinal glial cells of the guineapig. NeuroReport 13:1037-1040 [PubMed: 12060804]

318. Radian R, Kanner BI (1983) Stoichiometry of sodium- and chloride-coupled gammaaminobutyric acid transport by synaptic plasma membrane vesicles isolated from rat brain. Biochemistry 22:1236-1241 [PubMed: 6838850]

319. Rauen T, Rothstein JD, Wassle H (1996) Differential expression of three glutamate transporter subtypes in the rat retina. Cell Tissue Res 286:325-336 [PubMed: 8929335]

320. Ray A, Zoidl G, Weickert S, Wahle P, Dermietzel R (2005) Site-specific and developmental expression of pannexin1 in the mouse nervous system. Eur J Neurosci 21:3277-3290 [PubMed: 16026466]

321. Reese KA, Caldwell JH (1999) Immunocytochemical localization of NaCh6 in cultured spinal cord astrocytes. Glia 26:92-96 [PubMed: 10088676]

322. Requardt RP, Hirrlinger PG, Wilhelm F, Winkler U, Besser S, Hirrlinger J (2012) $\mathrm{Ca}^{2+}$ signals of astrocytes are modulated by the NAD ${ }^{+} / \mathrm{NADH}$ redox state. J Neurochem 120:1014-1025 [PubMed: 22299833] 
323. Reyes RC, Verkhratsky A, Parpura V (2012) Plasmalemmal $\mathrm{Na}^{+} / \mathrm{Ca}^{2+}$ exchanger modulates $\mathrm{Ca}^{2+}$-dependent exocytotic release of glutamate from rat cortical astrocytes. ASN Neuro 4

324. Reyes RC, Verkhratsky A, Parpura V (2013) TRPC1-mediated $\mathrm{Ca}^{2+}$ and $\mathrm{Na}^{+}$signalling in astroglia: differential filtering of extracellular cations. Cell Calcium (in press)

325. Ribak CE, Tong WM, Brecha NC (1996) GABA plasma membrane transporters, GAT-1 and GAT-3, display different distributions in the rat hippocampus. J Comp Neurol 367:595-606 [PubMed: 8731228]

326. Riquelme R, Miralles CP, De Blas AL (2002) Bergmann glia GABA receptors concentrate on the glial processes that wrap inhibitory synapses. J Neurosci 22:10720-10730 [PubMed: 12486165]

327. Ronco V, Grolla AA, Glasnov TN, Canonico PL, Verkhratsky A, Genazzani AA, Lim D (2014) Differential deregulation of astrocytic calcium signalling by amyloid- $\beta$, TNFa, IL- $1 \beta$ and LPS. Cell Calcium 55:219-229 [PubMed: 24656753]

328. Rose CR, Karus C (2013) Two sides of the same coin: sodium homeostasis and signaling in astrocytes under physiological and pathophysiological conditions. Glia 61:1191-1205 [PubMed: 23553639]

329. Rose CR, Ransom BR (1996) Intracellular sodium homeostasis in rat hippocampal astrocytes. J Physiol 491(Pt 2):291-305 [PubMed: 8866855]

330. Rose CR, Ransom BR (1997) Regulation of intracellular sodium in cultured rat hippocampal neurones. J Physiol 499(Pt 3):573-587 [PubMed: 9130155]

331. Rose CR, Verkhratsky A (2016) Principles of sodium homeostasis and sodium signalling in astroglia. Glia 64:1611-1627 [PubMed: 26919326]

332. Roux L, Benchenane K, Rothstein JD, Bonvento G, Giaume C (2011) Plasticity of astroglial networks in olfactory glomeruli. Proc Natl Acad Sci USA 108:18442-18446 [PubMed: 21997206]

333. Roux MJ, Supplisson S (2000) Neuronal and glial glycine transporters have different stoichiometries. Neuron 25:373-383 [PubMed: 10719892]

334. Roy ML, Saal D, Perney T, Sontheimer H, Waxman SG, Kaczmarek LK (1996) Manipulation of the delayed rectifier $\mathrm{K}_{\mathrm{V}} 1.5$ potassium channel in glial cells by antisense oligodeoxynucleotides. Glia 18:177-184 [PubMed: 8915650]

335. Rubini P, Pagel G, Mehri S, Marquardt P, Riedel T, Illes P (2014) Functional P2X 7 receptors at cultured hippocampal astrocytes but not neurons. Naunyn Schmiedebergs Arch Pharmacol 387:943-954 [PubMed: 24961463]

336. Rungta RL, Bernier LP, Dissing-Olesen L, Groten CJ, LeDue JM, Ko R, Drissler S, MacVicar BA (2016) $\mathrm{Ca}^{2+}$ transients in astrocyte fine processes occur via $\mathrm{Ca}^{2+}$ influx in the adult mouse hippocampus. Glia 64:2093-2103 [PubMed: 27479868]

337. Rusnakova V, Honsa P, Dzamba D, Stahlberg A, Kubista M, Anderova M (2013) Heterogeneity of astrocytes: from development to injury-single cell gene expression. PLoS ONE 8:e69734 [PubMed: 23940528]

338. Saab AS, Neumeyer A, Jahn HM, Cupido A, Simek AA, Boele HJ, Scheller A, Le Meur K, Gotz M, Monyer H, Sprengel R, Rubio ME, Deitmer JW, De Zeeuw CI, Kirchhoff F (2012) Bergmann glial AMPA receptors are required for fine motor coordination. Science 337:749-753 [PubMed: 22767895]

339. Salm AK, McCarthy KD (1990) Norepinephrine-evoked calcium transients in cultured cerebral type 1 astroglia. Glia 3:529-538 [PubMed: 2148555]

340. Sanchez C, Galve-Roperh I, Rueda D, Guzman M (1998) Involvement of sphingomyelin hydrolysis and the mitogen-activated protein kinase cascade in the Delta9-tetrahydrocannabinolinduced stimulation of glucose metabolism in primary astrocytes. Mol Pharmacol 54:834-843 [PubMed: 9804618]

341. Sanden N, Thorlin T, Blomstrand F, Persson PA, Hansson E (2000) 5-Hydroxytryptamine 2 B receptors stimulate $\mathrm{Ca}^{2+}$ increases in cultured astrocytes from three different brain regions. Neurochem Int 36:427-434 [PubMed: 10733010] 
342. Satoh J, Tabunoki H, Yamamura T, Arima K, Konno H (2007) Human astrocytes express aquaporin-1 and aquaporin-4 in vitro and in vivo. Neuropathology 27:245-256 [PubMed: 17645239]

343. Scalise M, Pochini L, Galluccio M, Indiveri C (2016) Glutamine transport. From energy supply to sensing and beyond. Biochim Biophys Acta

344. Scemes E, Giaume C (2006) Astrocyte calcium waves: what they are and what they do. Glia 54:716-725 [PubMed: 17006900]

345. Schaller KL, Krzemien DM, Yarowsky PJ, Krueger BK, Caldwell JH (1995) A novel, abundant sodium channel expressed in neurons and glia. J Neurosci 15:3231-3242 [PubMed: 7751906]

346. Scharfman HE, Binder DK (2013) Aquaporin-4 water channels and synaptic plasticity in the hippocampus. Neurochem Int 63:702-711 [PubMed: 23684954]

347. Schipke CG, Heuser I, Peters O (2011) Antidepressants act on glial cells: SSRIs and serotonin elicit astrocyte calcium signaling in the mouse prefrontal cortex. J Psychiatr Res 45:242-248 [PubMed: 20619420]

348. Schipke CG, Ohlemeyer C, Matyash M, Nolte C, Kettenmann H, Kirchhoff F (2001) Astrocytes of the mouse neocortex express functional N-methyl-D-aspartate receptors. FASEB J. 15:12701272 [PubMed: 11344110]

349. Schroeter S, Apparsundaram S, Wiley RG, Miner LH, Sesack SR, Blakely RD (2000) Immunolocalization of the cocaine- and antidepressant-sensitive l-norepinephrine transporter. $\mathrm{J}$ Comp Neurol 420:211-232 [PubMed: 10753308]

350. Seifert G, Huttmann K, Binder DK, Hartmann C, Wyczynski A, Neusch C, Steinhauser C (2009) Analysis of astroglial $\mathrm{K}^{+}$channel expression in the developing hippocampus reveals a predominant role of the $\mathrm{K}_{\mathrm{ir}} 4.1$ subunit. J Neurosci 29:7474-7488 [PubMed: 19515915]

351. Seifert G, Steinhauser C (1995) Glial cells in the mouse hippocampus express AMPA receptors with an intermediate $\mathrm{Ca}^{2+}$ permeability. Eur J Neurosci 7:1872-1881 [PubMed: 8528461]

352. Shao Y, Sutin J (1992) Expression of adrenergic receptors in individual astrocytes and motor neurons isolated from the adult rat brain. Glia 6:108-117 [PubMed: 1328049]

353. Sharma G, Vijayaraghavan S (2001) Nicotinic cholinergic signaling in hippocampal astrocytes involves calcium-induced calcium release from intracellular stores. Proc Natl Acad Sci USA 98:4148-4153 [PubMed: 11259680]

354. Sharp AH, Nucifora FC Jr, Blondel O, Sheppard CA, Zhang C, Snyder SH, Russell JT, Ryugo DK, Ross CA (1999) Differential cellular expression of isoforms of inositol 1,4,5-triphosphate receptors in neurons and glia in brain. J Comp Neurol 406:207-220 [PubMed: 10096607]

355. Shelton MK, McCarthy KD (2000) Hippocampal astrocytes exhibit $\mathrm{Ca}^{2+}$-elevating muscarinic cholinergic and histaminergic receptors in situ. J Neurochem 74:555-563 [PubMed: 10646506]

356. Sheppard CA, Simpson PB, Sharp AH, Nucifora FC, Ross CA, Lange GD, Russell JT (1997) Comparison of type 2 inositol 1,4,5-trisphosphate receptor distribution and subcellular $\mathrm{Ca}^{2+}$ release sites that support $\mathrm{Ca}^{2+}$ waves in cultured astrocytes. J Neurochem 68:2317-2327 [PubMed: 9166724]

357. Sherwood MW, Arizono M, Hisatsune C, Bannai H, Ebisui E, Sherwood JL, Panatier A, Oliet $\mathrm{SH}$, Mikoshiba $\mathrm{K}$ (2017) Astrocytic $\mathrm{IP}_{3}$ Rs: contribution to $\mathrm{Ca}^{2+}$ signalling and hippocampal LTP. Glia 65:502-513 [PubMed: 28063222]

358. Shibasaki K, Hosoi N, Kaneko R, Tominaga M, Yamada K (2016) Glycine release from astrocytes via functional reversal of GlyT1. J Neurochem

359. Shigetomi E, Bowser DN, Sofroniew MV, Khakh BS (2008) Two forms of astrocyte calcium excitability have distinct effects on NMDA receptor-mediated slow inward currents in pyramidal neurons. J Neurosci 28:6659-6663 [PubMed: 18579739]

360. Shigetomi E, Jackson-Weaver O, Huckstepp RT, O’Dell TJ, Khakh BS (2013) TRPA1 channels are regulators of astrocyte basal calcium levels and long-term potentiation via constitutive Dserine release. J Neurosci 33:10143-10153 [PubMed: 23761909]

361. Shigetomi E, Patel S, Khakh BS (2016) Probing the complexities of astrocyte calcium signaling. Trends Cell Biol 26:300-312 [PubMed: 26896246]

362. Shigetomi E, Tong X, Kwan KY, Corey DP, Khakh BS (2012) TRPA1 channels regulate astrocyte resting calcium and inhibitory synapse efficacy through GAT-3. Nat Neurosci 15:70-80 
363. Sik A, Smith RL, Freund TF (2000) Distribution of chloride channel-2-immunoreactive neuronal and astrocytic processes in the hippocampus. Neuroscience 101:51-65 [PubMed: 11068136]

364. Simpson PB, Holtzclaw LA, Langley DB, Russell JT (1998) Characterization of ryanodine receptors in oligodendrocytes, type 2 astrocytes, and O-2A progenitors. J Neurosci Res 52:468482 [PubMed: 9589392]

365. Skatchkov SN, Rojas L, Eaton MJ, Orkand RK, Biedermann B, Bringmann A, Pannicke T, Veh RW, Reichenbach A (2002) Functional expression of $\mathrm{K}_{\mathrm{ir}} 6.1 / \mathrm{SUR} 1-\mathrm{K}_{\mathrm{ATP}}$ channels in frog retinal Muller glial cells. Glia 38:256-267 [PubMed: 11968063]

366. Skowronska M, Zielinska M, Albrecht J (2010) Stimulation of natriuretic peptide receptor C attenuates accumulation of reactive oxygen species and nitric oxide synthesis in ammoniatreated astrocytes. J Neurochem 115:1068-1076 [PubMed: 20854429]

367. Skucas VA, Mathews IB, Yang J, Cheng Q, Treister A, Duffy AM, Verkman AS, Hempstead BL, Wood MA, Binder DK, Scharfman HE (2011) Impairment of select forms of spatial memory and neurotrophin-dependent synaptic plasticity by deletion of glial aquaporin-4. J Neurosci 31:63926397 [PubMed: 21525279]

368. Smyth JT, Dehaven WI, Jones BF, Mercer JC, Trebak M, Vazquez G, Putney JW Jr (2006) Emerging perspectives in store-operated $\mathrm{Ca}^{2+}$ entry: roles of Orai, Stim and TRP. Biochim Biophys Acta 1763:1147-1160 [PubMed: 17034882]

369. Sohl G, Odermatt B, Maxeiner S, Degen J, Willecke K (2004) New insights into the expression and function of neural connexins with transgenic mouse mutants. Brain Res Brain Res Rev 47:245-259 [PubMed: 15572175]

370. Solenov E, Watanabe H, Manley GT, Verkman AS (2004) Sevenfold-reduced osmotic water permeability in primary astrocyte cultures from AQP-4-deficient mice, measured by a fluorescence quenching method. Am J Physiol Cell Physiol 286:C426-C432 [PubMed: 14576087]

371. Sontheimer H, Black JA, Ransom BR, Waxman SG (1992) Ion channels in spinal cord astrocytes in vitro. I. Transient expression of high levels of $\mathrm{Na}^{+}$and $\mathrm{K}^{+}$channels. J Neurophysiol 68:9851000 [PubMed: 1331358]

372. Sontheimer H, Fernandez-Marques E, Ullrich N, Pappas CA, Waxman SG (1994) Astrocyte $\mathrm{Na}^{+}$ channels are required for maintenance of $\mathrm{Na}^{+} / \mathrm{K}^{+}$-ATPase activity. J Neurosci 14:2464-2475 [PubMed: 8182422]

373. Sontheimer H, Minturn JE, Black JA, Ransom BR, Waxman SG (1991) Two types of $\mathrm{Na}^{+}-$ currents in cultured rat optic nerve astrocytes: changes with time in culture and with age of culture derivation. J Neurosci Res 30:275-287 [PubMed: 1665865]

374. Sontheimer H, Waxman SG (1992) Ion channels in spinal cord astrocytes in vitro. II. Biophysical and pharmacological analysis of two $\mathrm{Na}^{+}$current types. J Neurophysiol 68:1001-1011 [PubMed: 1331355]

375. Srinivasan R, Huang BS, Venugopal S, Johnston AD, Chai H, Zeng H, Golshani P, Khakh BS (2015) $\mathrm{Ca}^{2+}$ signaling in astrocytes from Ip3r2 $2^{-/-}$mice in brain slices and during startle responses in vivo. Nat Neurosci 18:708-717 [PubMed: 25894291]

376. Steinhauser C, Jabs R, Kettenmann H (1994) Properties of GABA and glutamate responses in entified glial cells of the mouse hippocampal slice. Hippocampus 4:19-35 [PubMed: 7914797]

377. Stenovec M, Kreft M, Grilc S, Pangrsic T, Zorec R (2008) EAAT2 density at the astrocyte plasma membrane and $\mathrm{Ca}^{(2+)}$-regulated exocytosis. Mol Membr Biol 25:203-215 [PubMed: 18428036]

378. Stephens GJ, Cholewinski AJ, Wilkin GP, Djamgoz MB (1993) Calcium-mobilizing and electrophysiological effects of bradykinin on cortical astrocyte subtypes in culture. Glia 9:269279 [PubMed: 8112820]

379. Stiene-Martin A, Gurwell JA, Hauser KF (1991) Morphine alters astrocyte growth in primary cultures of mouse glial cells: evidence for a direct effect of opiates on neural maturation. Brain Res Dev Brain Res 60:1-7 [PubMed: 1914143]

380. Stonehouse AH, Pringle JH, Norman RI, Stanfield PR, Conley EC, Brammar WJ (1999) Characterisation of $\mathrm{K}_{\mathrm{ir}} 2.0$ proteins in the rat cerebellum and hippocampus by polyclonal antibodies. Histochem Cell Biol 112:457-465 [PubMed: 10651097] 
381. Storck T, Schulte S, Hofmann K, Stoffel W (1992) Structure, expression, and functional analysis of a $\mathrm{Na}^{+}$-dependent glutamate/aspartate transporter from rat brain. Proc Natl Acad Sci USA 89:10955-10959 [PubMed: 1279699]

382. Suadicani SO, Brosnan CF, Scemes E (2006) P2X 7 receptors mediate ATP release and amplification of astrocytic intercellular $\mathrm{Ca}^{2+}$ signaling. J Neurosci 26:1378-1385 [PubMed: 16452661]

383. Sumners C, Tang W, Paulding W, Raizada MK (1994) Peptide receptors in astroglia: focus on angiotensin II and atrial natriuretic peptide. Glia 11:110-116 [PubMed: 7927641]

384. Sun L, Kosugi Y, Kawakami E, Piao YS, Hashimoto T, Oyanagi K (2009) Magnesium concentration in the cerebrospinal fluid of mice and its response to changes in serum magnesium concentration. Magnes Res 22:266-272 [PubMed: 20228005]

385. Sun W, McConnell E, Pare JF, Xu Q, Chen M, Peng W, Lovatt D, Han X, Smith Y, Nedergaard M (2013) Glutamate-dependent neuroglial calcium signaling differs between young and adult brain. Science 339:197-200 [PubMed: 23307741]

386. Takata N, Mishima T, Hisatsune C, Nagai T, Ebisui E, Mikoshiba K, Hirase H (2011) Astrocyte calcium signaling transforms cholinergic modulation to cortical plasticity in vivo. J Neurosci 31:18155-18165 [PubMed: 22159127]

387. Takeda H, Inazu M, Matsumiya T (2002) Astroglial dopamine transport is mediated by norepinephrine transporter. Naunyn Schmiedebergs Arch Pharmacol. 366:620-623 [PubMed: 12444505]

388. Takuma K, Matsuda T, Hashimoto H, Kitanaka J, Asano S, Kishida Y, Baba A (1996) Role of Na ${ }_{-}^{+} \mathrm{Ca}^{2+}$ exchanger in agonist-induced $\mathrm{Ca}^{2+}$ signaling in cultured rat astrocytes. J Neurochem 67:1840-1845 [PubMed: 8863488]

389. Talantova M, Sanz-Blasco S, Zhang X, Xia P, Akhtar MW, Okamoto S, Dziewczapolski G, Nakamura T, Cao G, Pratt AE, Kang YJ, Tu S, Molokanova E, McKercher SR, Hires SA, Sason H, Stouffer DG, Buczynski MW, Solomon JP, Michael S, Powers ET, Kelly JW, Roberts A, Tong G, Fang-Newmeyer T, Parker J, Holland EA, Zhang D, Nakanishi N, Chen HS, Wolosker H, Wang Y, Parsons LH, Ambasudhan R, Masliah E, Heinemann SF, Pina-Crespo JC, Lipton SA (2013) Abeta induces astrocytic glutamate release, extrasynaptic NMDA receptor activation, and synaptic loss. Proc Natl Acad Sci USA 110:E2518-E2527 [PubMed: 23776240]

390. Teaktong T, Graham A, Court J, Perry R, Jaros E, Johnson M, Hall R, Perry E (2003) Alzheimer's disease is associated with a selective increase in a 7 nicotinic acetylcholine receptor immunoreactivity in astrocytes. Glia. 41:207-211 [PubMed: 12509811]

391. Teather LA, Lee RK, Wurtman RJ (2002) Platelet-activating factor increases prostaglandin $E_{2}$ release from astrocyte-enriched cortical cell cultures. Brain Res 946:87-95 [PubMed: 12133598]

392. Tence M, Ezan P, Amigou E, Giaume C (2012) Increased interaction of connexin43 with zonula occludens-1 during inhibition of gap junctions by $\mathrm{G}$ protein-coupled receptor agonists. Cell Signal 24:86-98 [PubMed: 21872657]

393. Teoh R, Kum W, Cockram CS, Young JD, Nicholls MG (1989) Mouse astrocytes possess specific ANP receptors which are linked to cGMP production. Clin Exp Pharmacol Physiol 16:323-327 [PubMed: 2545396]

394. Theparambil SM, Naoshin Z, Thyssen A, Deitmer JW (2015) Reversed electrogenic sodium bicarbonate cotransporter 1 is the major acid loader during recovery from cytosolic alkalosis in mouse cortical astrocytes. J Physiol 593:3533-3547 [PubMed: 25990710]

395. Thomzig A, Wenzel M, Karschin C, Eaton MJ, Skatchkov SN, Karschin A, Veh RW (2001) $\mathrm{K}_{\mathrm{ir}} 6.1$ is the principal pore-forming subunit of astrocyte but not neuronal plasma membrane KATP channels. Mol Cell Neurosci 18:671-690 [PubMed: 11749042]

396. Thorlin T, Eriksson PS, Persson PA, Aberg ND, Hansson E, Ronnback L (1998) $\delta$-opioid receptors on astroglial cells in primary culture: mobilization of intracellular free calcium via a pertussis sensitive G protein. Neuropharmacology 37:299-311 [PubMed: 9681928]

397. Todd AC, Marx MC, Hulme SR, Broer S, Billups B (2017) SNAT3-mediated glutamine transport in perisynaptic astrocytes in situ is regulated by intracellular sodium. Glia 
398. Toth A, Boczan J, Kedei N, Lizanecz E, Bagi Z, Papp Z, Edes I, Csiba L, Blumberg PM (2005) Expression and distribution of vanilloid receptor 1 (TRPV1) in the adult rat brain. Brain Res Mol Brain Res 135:162-168 [PubMed: 15857679]

399. Tuschick S, Kirischuk S, Kirchhoff F, Liefeldt L, Paul M, Verkhratsky A, Kettenmann H (1997) Bergmann glial cells in situ express endothelin ${ }_{B}$ receptors linked to cytoplasmic calcium signals. Cell Calcium 21:409-419 [PubMed: 9223677]

400. Ubl JJ, Reiser G (1997) Characteristics of thrombin-induced calcium signals in rat astrocytes. Glia. 21:361-369 [PubMed: 9419011]

401. Ubl JJ, Vohringer C, Reiser G (1998) Co-existence of two types of $\left[\mathrm{Ca}^{2+}\right]_{\mathrm{i}}$-inducing proteaseactivated receptors (PAR-1 and PAR-2) in rat astrocytes and C6 glioma cells. Neuroscience 86:597-609 [PubMed: 9881872]

402. Unichenko P, Myakhar O, Kirischuk S (2012) Intracellular $\mathrm{Na}^{+}$concentration influences shortterm plasticity of glutamate transporter-mediated currents in neocortical astrocytes. Glia 60:605614 [PubMed: 22279011]

403. Untiet V, Kovermann P, Gerkau NJ, Gensch T, Rose CR, Fahlke C (2017) Glutamate transporterassociated anion channels adjust intracellular chloride concentrations during glial maturation. Glia 65:388-400 [PubMed: 27859594]

404. Vandenberg RJ, Ryan RM (2013) Mechanisms of glutamate transport. Physiol Rev 93:1621-1657 [PubMed: 24137018]

405. Venance L, Premont J, Glowinski J, Giaume C (1998) Gap junctional communication and pharmacological heterogeneity in astrocytes cultured from the rat striatum. J Physiol 510(Pt 2):429-440 [PubMed: 9705994]

406. Verkhratsky A, Butt AM (2013) Glial physiology and pathophysiology. Wiley-Blackwell, Chichester, p 560

407. Verkhratsky A, Kettenmann H (1996) Calcium signalling in glial cells. Trends Neurosci 19:346352 [PubMed: 8843604]

408. Verkhratsky A, Nedergaard M (2014) Astroglial cradle in the life of the synapse. Philos Trans R Soc Lond B Biol Sci 369:20130595 [PubMed: 25225089]

409. Verkhratsky A, Nedergaard M (2016). The homeostatic astroglia emerges from evolutionary specialization of neural cells. Philos Trans R Soc Lond B Biol Sci 371

410. Verkhratsky A, Nedergaard M (2018) Physiology of astroglia. Physiol Rev 98:239-389 [PubMed: 29351512]

411. Verkhratsky A, Orkand RK, Kettenmann H (1998) Glial calcium: homeostasis and signaling function. Physiol Rev 78:99-141 [PubMed: 9457170]

412. Verkhratsky A, Parpura V (2014) Store-operated calcium entry in neuroglia. Neurosci Bull 30:125-133 [PubMed: 23677809]

413. Verkhratsky A, Parpura V (2015) Physiology of astroglia: channels, receptors, transporters, ion signaling and gliotransmission. Morgan \& Claypool Publishers, 172pp

414. Verkhratsky A, Rodriguez JJ, Parpura V (2012) Calcium signalling in astroglia. Mol Cell Endocrinol 353:45-56 [PubMed: 21945602]

415. Verkhratsky A, Trebak M, Perocchi F, Khananshvili D, Sekler I (2018) Crosslink between calcium and sodium signalling. Exp Physiol 103:157-169 [PubMed: 29210126]

416. Waldmann R, Champigny G, Bassilana F, Voilley N, Lazdunski M (1995) Molecular cloning and functional expression of a novel amiloride-sensitive $\mathrm{Na}^{+}$channel. J Biol Chem 270:27411-27414 [PubMed: 7499195]

417. Wang CM, Chang YY, Sun SH (2003) Activation of P2X 7 purinoceptor-stimulated TGF- $\beta 1$ mRNA expression involves PKC/MAPK signalling pathway in a rat brain-derived type-2 astrocyte cell line, RBA-2. Cell Signal 15:1129-1137 [PubMed: 14575868]

418. Wang D, Yan B, Rajapaksha WR, Fisher TE (2009) The expression of voltage-gated $\mathrm{ca}^{2+}$ channels in pituicytes and the up-regulation of L-type $\mathrm{ca}^{2+}$ channels during water deprivation. $\mathrm{J}$ Neuroendocrinol 21:858-866 [PubMed: 19686441]

419. Wang F, Du T, Liang C, Verkhratsky A, Peng L (2015) Ammonium increases $\mathrm{Ca}^{2+}$ signalling and upregulates expression of $\mathrm{Ca}_{\mathrm{v}} 1.2$ gene in astrocytes in primary cultures and in the in vivo brain. Acta Physiol (Oxf) 214:261-274 [PubMed: 25846713] 
420. Watanabe E, Hiyama TY, Shimizu H, Kodama R, Hayashi N, Miyata S, Yanagawa Y, Obata K, Noda M (2006) Sodium-level-sensitive sodium channel $\mathrm{Na}_{\mathrm{X}}$ is expressed in glial laminate processes in the sensory circumventricular organs. Am J Physiol Regul Integr Comp Physiol 290:R568-R576 [PubMed: 16223844]

421. Westenbroek RE, Bausch SB, Lin RC, Franck JE, Noebels JL, Catterall WA (1998) Upregulation of L-type $\mathrm{Ca}^{2+}$ channels in reactive astrocytes after brain injury, hypomyelination, and ischemia. J Neurosci 18:2321-2334 [PubMed: 9502793]

422. Woo DH, Han KS, Shim JW, Yoon BE, Kim E, Bae JY, Oh SJ, Hwang EM, Marmorstein AD, Bae YC, Park JY, Lee CJ (2012) TREK-1 and Best1 channels mediate fast and slow glutamate release in astrocytes upon GPCR activation. Cell 151:25-40 [PubMed: 23021213]

423. Yang F, Sun X, Ding Y, Ma H, Yang TO, Ma Y, Wei D, Li W, Xu T, Jiang W (2016) Astrocytic acid-sensing ion channel 1a contributes to the development of chronic epileptogenesis. Sci Rep 6:31581 [PubMed: 27526777]

424. Zafra F, Aragon C, Olivares L, Danbolt NC, Gimenez C, Storm-Mathisen J (1995) Glycine transporters are differentially expressed among CNS cells. J Neurosci 15:3952-3969 [PubMed: 7751957]

425. Zanassi P, Paolillo M, Montecucco A, Avvedimento EV, Schinelli S (1999) Pharmacological and molecular evidence for dopamine $\mathrm{D}_{1}$ receptor expression by striatal astrocytes in culture. $\mathrm{J}$ Neurosci Res 58:544-552 [PubMed: 10533046]

426. Zerangue N, Kavanaugh MP (1996) Flux coupling in a neuronal glutamate transporter. Nature 383:634-637 [PubMed: 8857541]

427. Zhang J, Li Y, Chen ZG, Dang H, Ding JH, Fan Y, Hu G (2013) Glia protein aquaporin-4 regulates aversive motivation of spatial memory in Morris water maze. CNS Neurosci Ther 19:937-944 [PubMed: 24165567]

428. Zhang S, Li B, Lovatt D, Xu J, Song D, Goldman SA, Nedergaard M, Hertz L, Peng L (2010) 5$\mathrm{HT}_{2 \mathrm{~B}}$ receptors are expressed on astrocytes from brain and in culture and are a chronic target for all five conventional 'serotonin-specific reuptake inhibitors'. Neuron Glia Biol 6:113-125 [PubMed: 20846463]

429. Zhang XD, Morishima S, Ando-Akatsuka Y, Takahashi N, Nabekura T, Inoue H, Shimizu T, Okada Y (2004) Expression of novel isoforms of the CIC-1 chloride channel in astrocytic glial cells in vitro. Glia. 47:46-57 [PubMed: 15139012]

430. Zhang Y, Chen K, Sloan SA, Bennett ML, Scholze AR, O’Keeffe S, Phatnani HP, Guarnieri P, Caneda C, Ruderisch N, Deng S, Liddelow SA, Zhang C, Daneman R, Maniatis T, Barres BA, Wu JQ (2014) An RNA-sequencing transcriptome and splicing database of glia, neurons, and vascular cells of the cerebral cortex. J Neurosci 34:11929-11947 [PubMed: 25186741]

431. Zhou M, Tanaka O, Suzuki M, Sekiguchi M, Takata K, Kawahara K, Abe H (2002) Localization of pore-forming subunit of the ATP-sensitive $\mathrm{K}^{+}$-channel, $\mathrm{K}_{\mathrm{ir}} 6.2$, in rat brain neurons and glial cells. Brain Res Mol Brain Res 101:23-32 [PubMed: 12007828]

432. Zhou M, Xu G, Xie M, Zhang X, Schools GP, Ma L, Kimelberg HK, Chen H (2009) TWIK-1 and TREK-1 are potassium channels contributing significantly to astrocyte passive conductance in rat hippocampal slices. J Neurosci 29:8551-8564 [PubMed: 19571146]

433. Zhou Y, Danbolt NC (2013) GABA and glutamate transporters in brain. Front Endocrinol (Lausanne) 4:165 [PubMed: 24273530]

434. Zhu H, Zhao Y, Wu H, Jiang N, Wang Z, Lin W, Jin J, Ji Y (2016) Remarkable alterations of Nav1.6 in reactive astrogliosis during epileptogenesis. Sci Rep 6:38108 [PubMed: 27905510]

435. Zhu SQ, Kum W, Ho SK, Young JD, Cockram CS (1990) Structure-function relationships of insulin receptor interactions in cultured mouse astrocytes. Brain Res 529:329-332 [PubMed: 1704285]

436. Zhu Z, Reiser G (2014) Signaling mechanism of protease activated receptor 1-induced proliferation of astrocytes: stabilization of hypoxia inducible factor-1alpha triggers glucose metabolism and accumulation of cyclin D1. Neurochem Int 79:20-32 [PubMed: 25280834]

437. Ziak D, Chvatal A, Sykova E (1998) Glutamate-, kainate- and NMDA-evoked membrane currents in identified glial cells in rat spinal cord slice. Physiol Res 47:365-375 [PubMed: 10052606] 
438. Zielinska M, Fresko I, Konopacka A, Felipo V, Albrecht J (2007) Hyperammonemia inhibits the natriuretic peptide receptor 2 (NPR-2)-mediated cyclic GMP synthesis in the astrocytic compartment of rat cerebral cortex slices. Neurotoxicology 28:1260-1263 [PubMed: 17629948] 


\begin{tabular}{|l|}
\hline \multicolumn{1}{|c|}{ Molecular homeostasis } \\
\hline Ion homeostasis $\left(\mathrm{K}^{*}, \mathrm{Cr}^{\prime}, \mathrm{Ca}^{2+}\right)$ \\
Regulation of $\mathrm{pH}$ \\
Water transport and homeostasis \\
Neurotransmitter homeostasis \\
(glutamate, $\mathrm{GABA}$, adenosine, \\
monoamines) \\
\hline
\end{tabular}

\section{Cellular \& network homeostasis}

Neurogenesis

Neuronal development and

neuronal guidance

Defining cyto-architecture of the CNS

Synaptogenesis, synaptic

maintenance and synaptic elimination

Synaptic plastiity

\begin{tabular}{|l|}
\hline \multicolumn{1}{|c|}{ Organ homoestasis } \\
\hline $\begin{array}{l}\text { Control over blood-brain barrier } \\
\text { Operation of the glymphatic system }\end{array}$ \\
\hline
\end{tabular}

Fig. 3.1.

Homoeostatic functions of astroglia

\begin{tabular}{|l|}
\hline \multicolumn{1}{|c|}{ Systemic homeostasis } \\
\hline Chemosensing \\
$\left(\mathrm{O}_{2}, \mathrm{CO}_{2}, \mathrm{pH}, \mathrm{Na} \mathrm{a}^{*}\right.$ glucose $)$ \\
Regulation of energy balance and \\
food intake \\
Sleep homeostat \\
\hline
\end{tabular}

\section{Metabolic homeostasis}

Formation of neuro-glio-vascular unit and glial-vascular interface Regulation of local blood flow Metabolic support

Glycogene synthesis and storage 


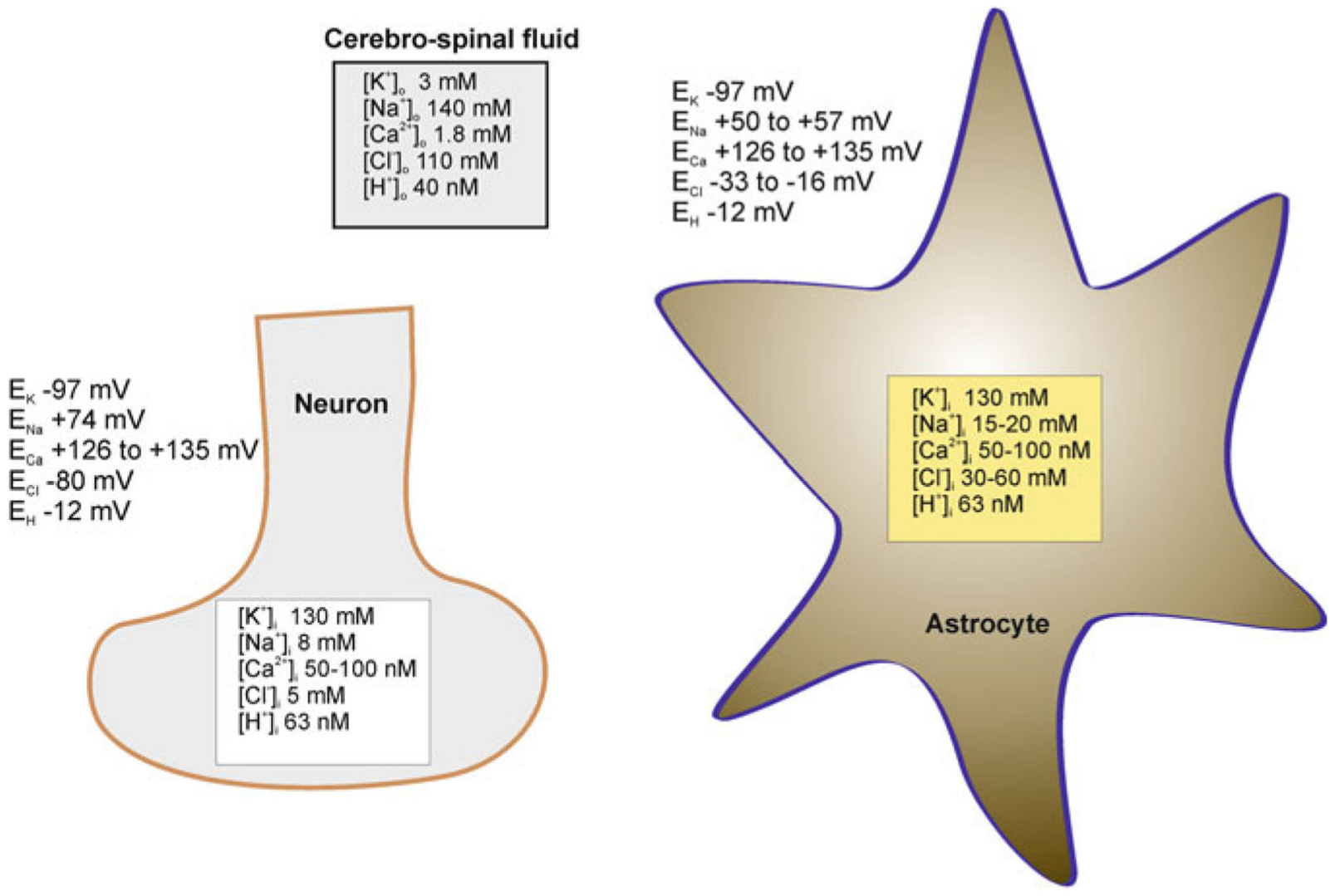

Fig. 3.2.

Ion distribution (and corresponding values of equilibrium potentials for different ions) between the cerebrospinal fluid and cytosol of astrocytes and neurones. Modified from [413] 
Inward rectifier

$\mathrm{K}^{+}$channels

$\mathrm{K}_{\mathrm{if}} 4.1$ (KCNJ10)

$\mathrm{K}_{\mathrm{in}} 5.1(\mathrm{KCNJ} 16)$

$\mathrm{K}_{\mathrm{ir}} 2.1,2.2,2.3(\mathrm{KCNJ} 2,12,4)$

$\mathrm{K}_{\mathrm{ir}} 3.1 / \mathrm{K}_{\mathrm{ir}} 3.4$ (KCNJ3/KCNJ5)

$\mathrm{K}_{\mathrm{ir}} 6.1(\mathrm{KCNJ} 8)$ and $\mathrm{K}_{\mathrm{ir}} 6.2(\mathrm{KCNJ} 11)$
Voltage-gated

$\mathrm{K}^{+}$channels

$\mathrm{K}_{\mathrm{v}} 1.1$ (KCNA1)

$\mathrm{K}_{\mathrm{v}} 1.2$ (KCNA2)

$\mathrm{K}_{\mathrm{v}} 1.5(\mathrm{KCNA5})$

$\mathrm{K}_{\mathrm{v}} 1.6(\mathrm{KCNA6})$

$\mathrm{K}_{\mathrm{v}} 1.4$ (KCNA4)

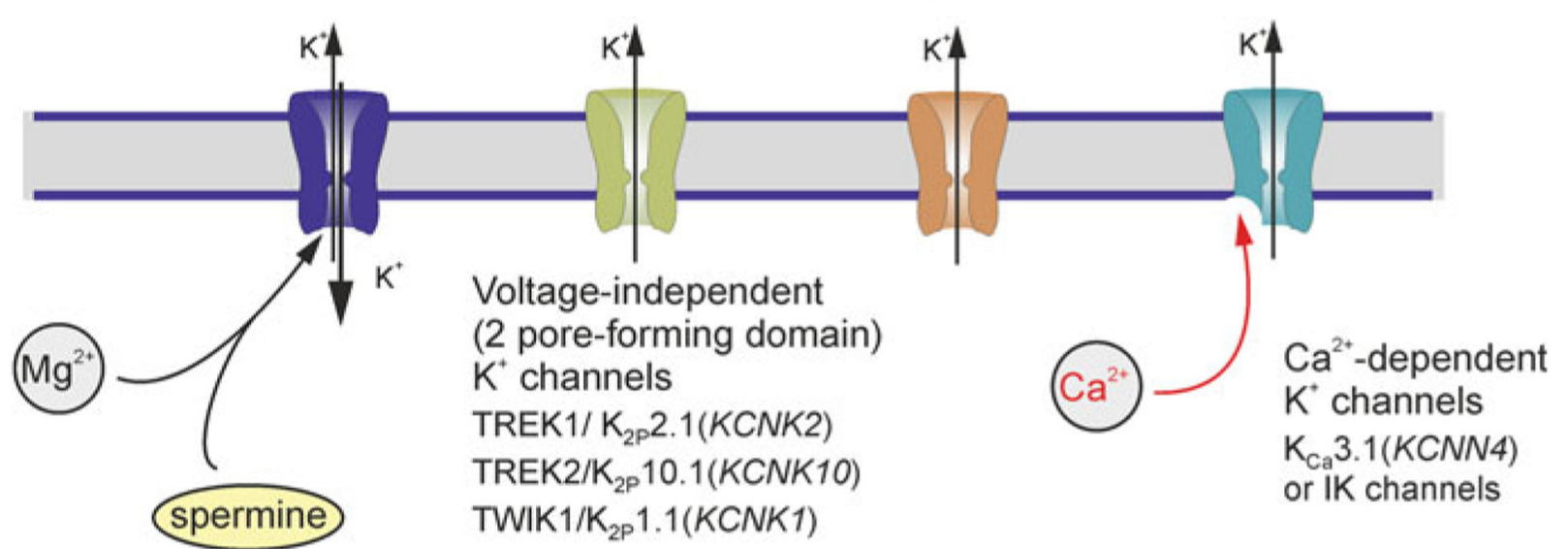

Fig. 3.3.

Potassium channels in astroglia. Gene names for a given channels are shown in parentheses. Modified from [413] 


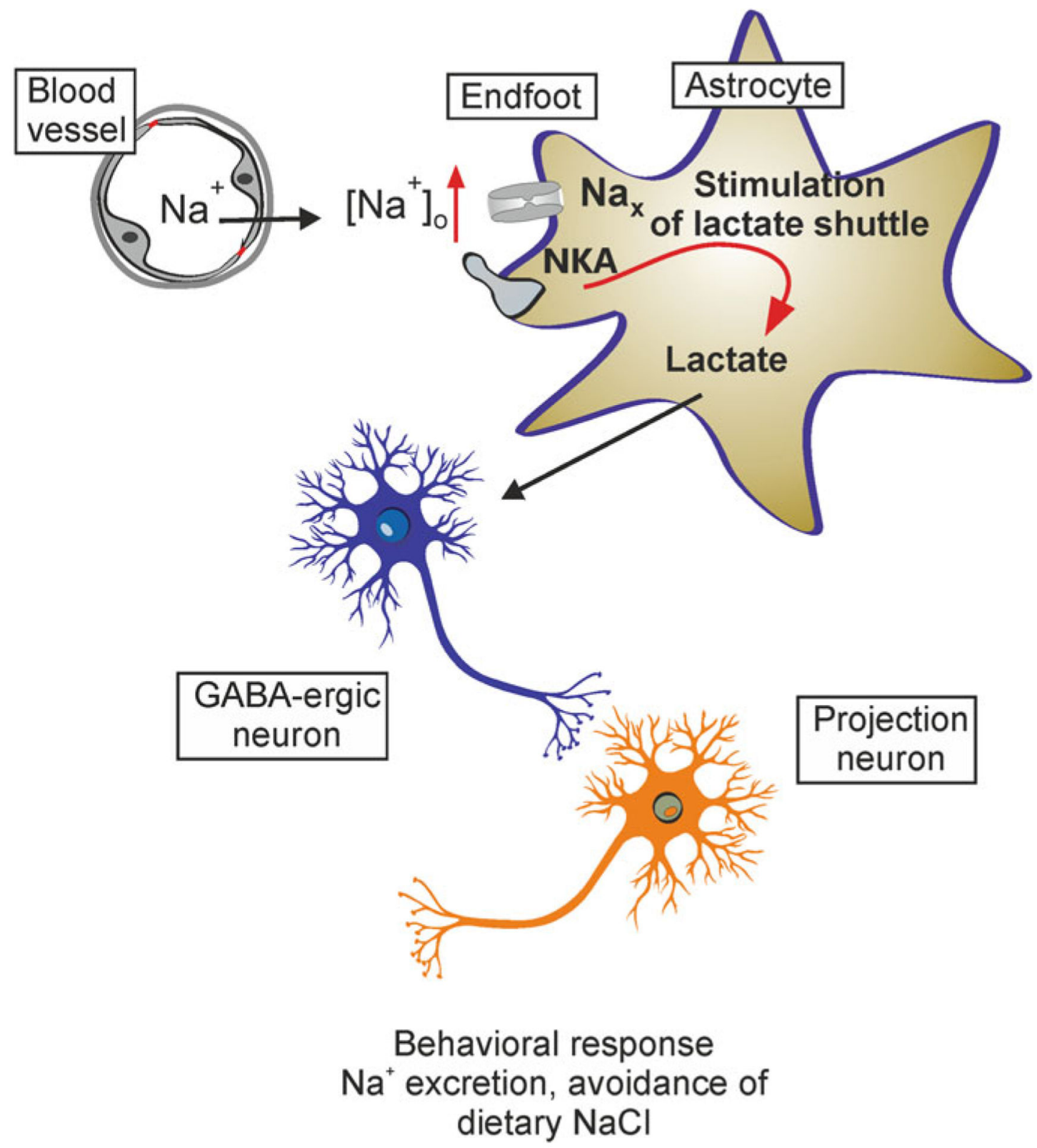

Fig. 3.4.

Astroglial $\mathrm{Na}_{\mathrm{x}}$ channels in systemic $\mathrm{Na}^{+}$regulation. Increases in blood $\mathrm{Na}^{+}$concentration activate $\mathrm{Na}_{\mathrm{x}}$ sodium channels localised in astrocytes residing in the subfornical organ. This leads to an increase in cytosolic $\mathrm{Na}^{+}$concentration, which in turn increases astroglial production of lactate. Lactate released by astrocytes is accumulated by neighbouring neurones (release and uptake carried by MCT1 in astrocytes and MCT4 in neurones, respectively), thus increasing ATP production in neurones. Increased ATP in turn closes neuronal ATP-sensitive $\mathrm{K}^{+}$channels, which results in depolarisation and subsequent activation of neuronal networks responsible for systemic $\mathrm{Na}^{+}$homeostasis. NKA, sodiumpotassium ATPase. Modified from [413] 

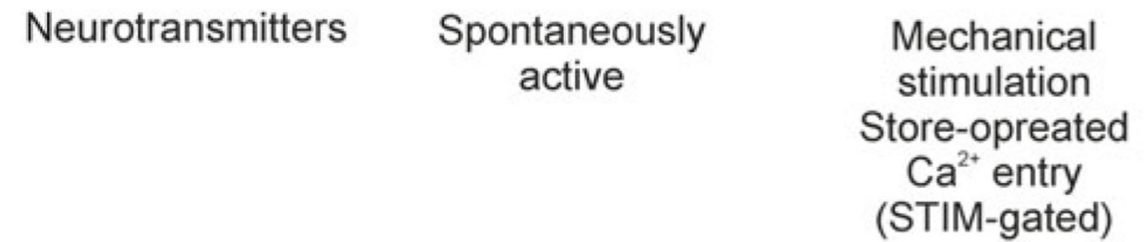

Osmotic challenge

(STIM-gated)

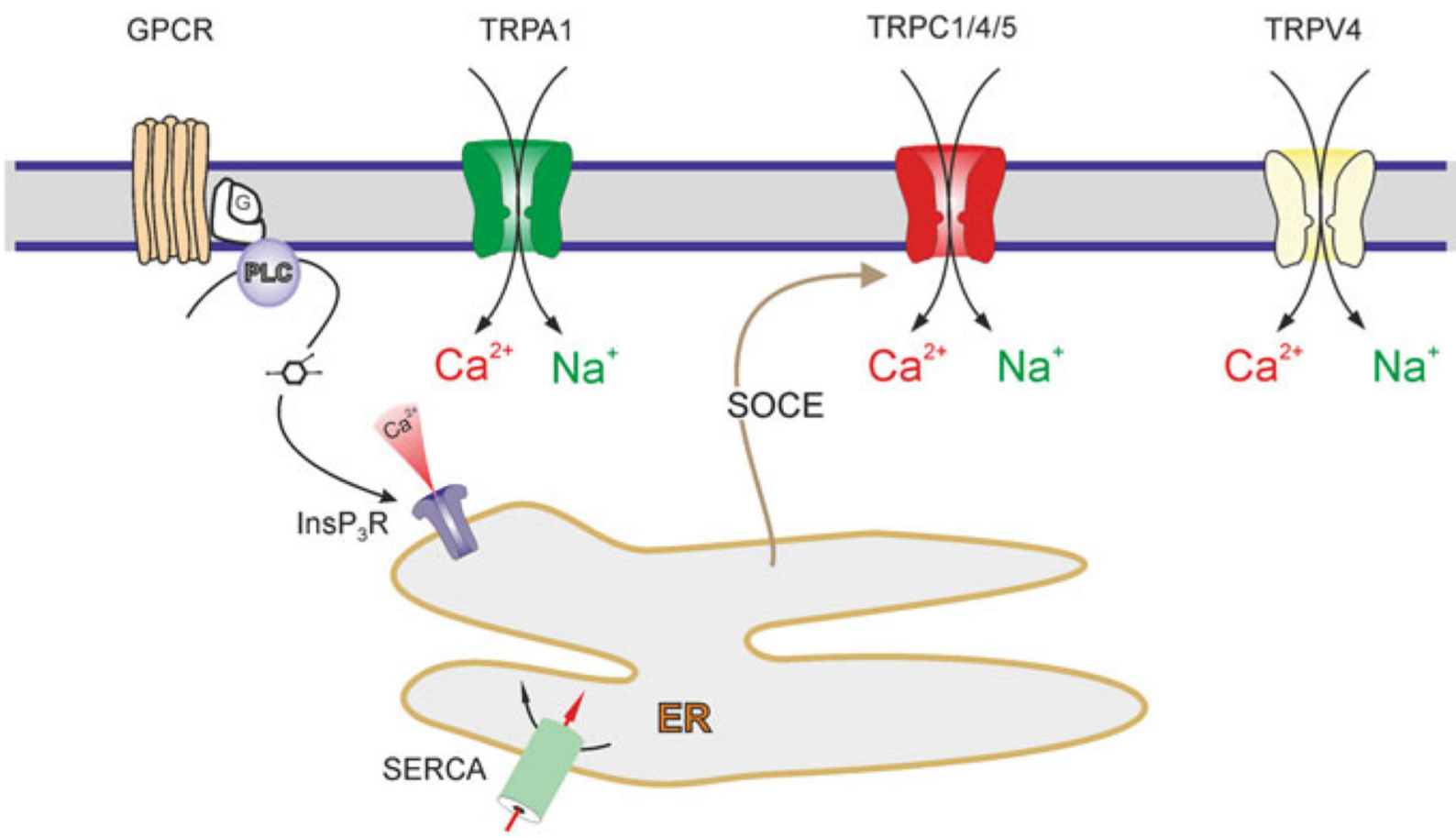

Fig. 3.5.

Astroglial TRP channels. Activation of G-protein coupled receptors (GPCR), i.e. metabotropic stimulation, can lead to production of $\mathrm{InsP}_{3}$ and release of $\mathrm{Ca}^{2+}$ from the ER store. The $\mathrm{Ca}^{2+}$ content of the ER store is refilled by Sarco(Endo)Plasmic Reticulum $\mathrm{Ca}^{2+}$ ATPase, i.e. SERCA. Depletion of the ER $\mathrm{Ca}^{2+}$ store activates (via STIM) TRPC channels in astrocytes which are therefore acting as a store-operated channel, contributing to capacitative $\mathrm{Ca}^{2+}$ entry. Activation of all TRP channels mediates $\mathrm{Ca}^{2+}$ and $\mathrm{Na}^{+}$influx. Modified from [413] 


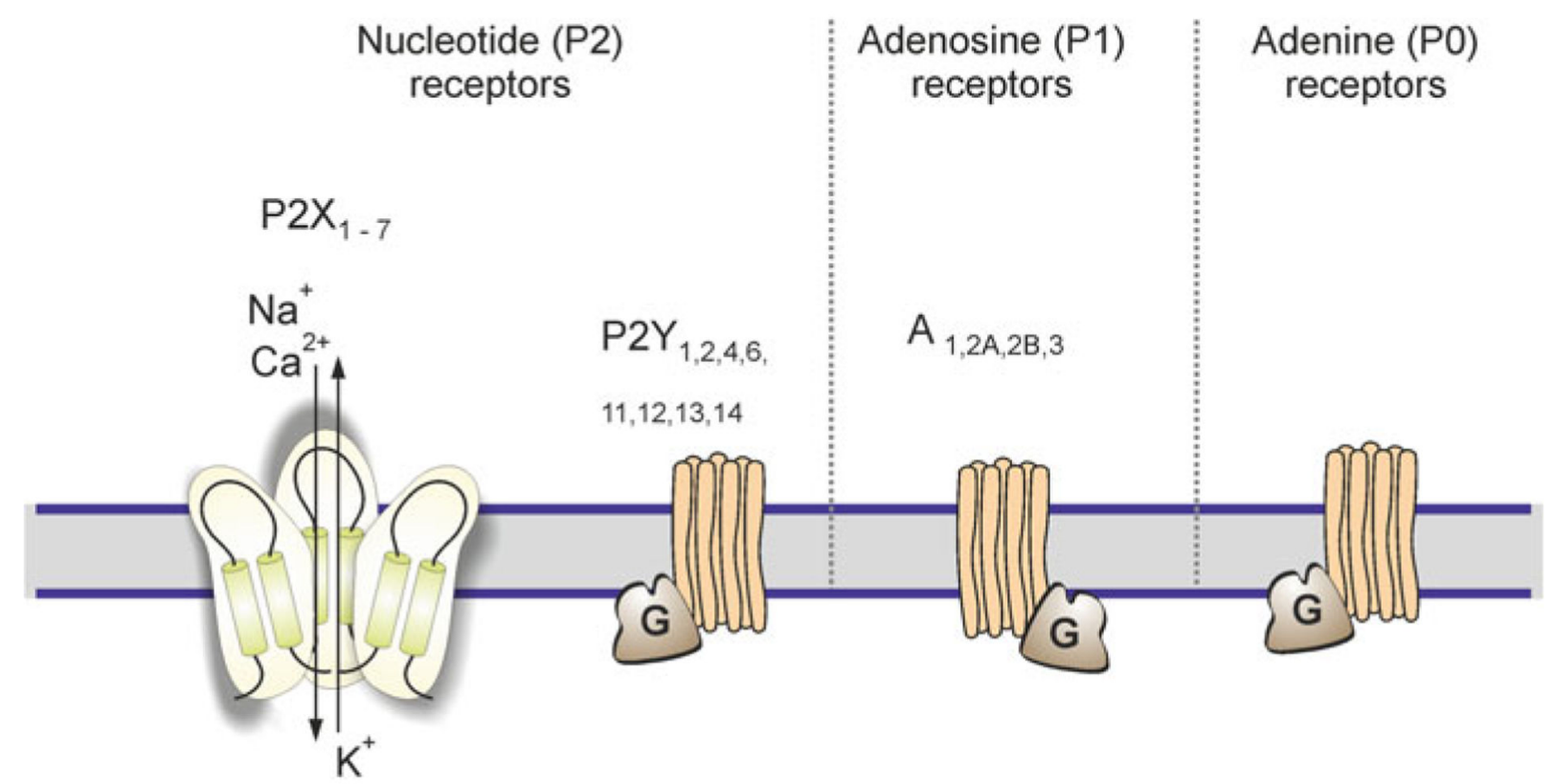

Fig. 3.6.

Classes of purinoreceptors. ATP after being released from neurones and glia is rapidly degrading by ectonucleotidases into ADP, AMP and adenosine, which act on P1 metabotropic adenosine receptors, $\mathrm{P} 2 \mathrm{X}$ ionotropic and $\mathrm{P} 2 \mathrm{Y}$ metabotropic nucleotide receptors. Adenine stimulates A0 adenine metabotorpic receptors, which hitherto have not been detected in astrocytes. Modified from [406] 
Ionotropic receptors (iGluRs)

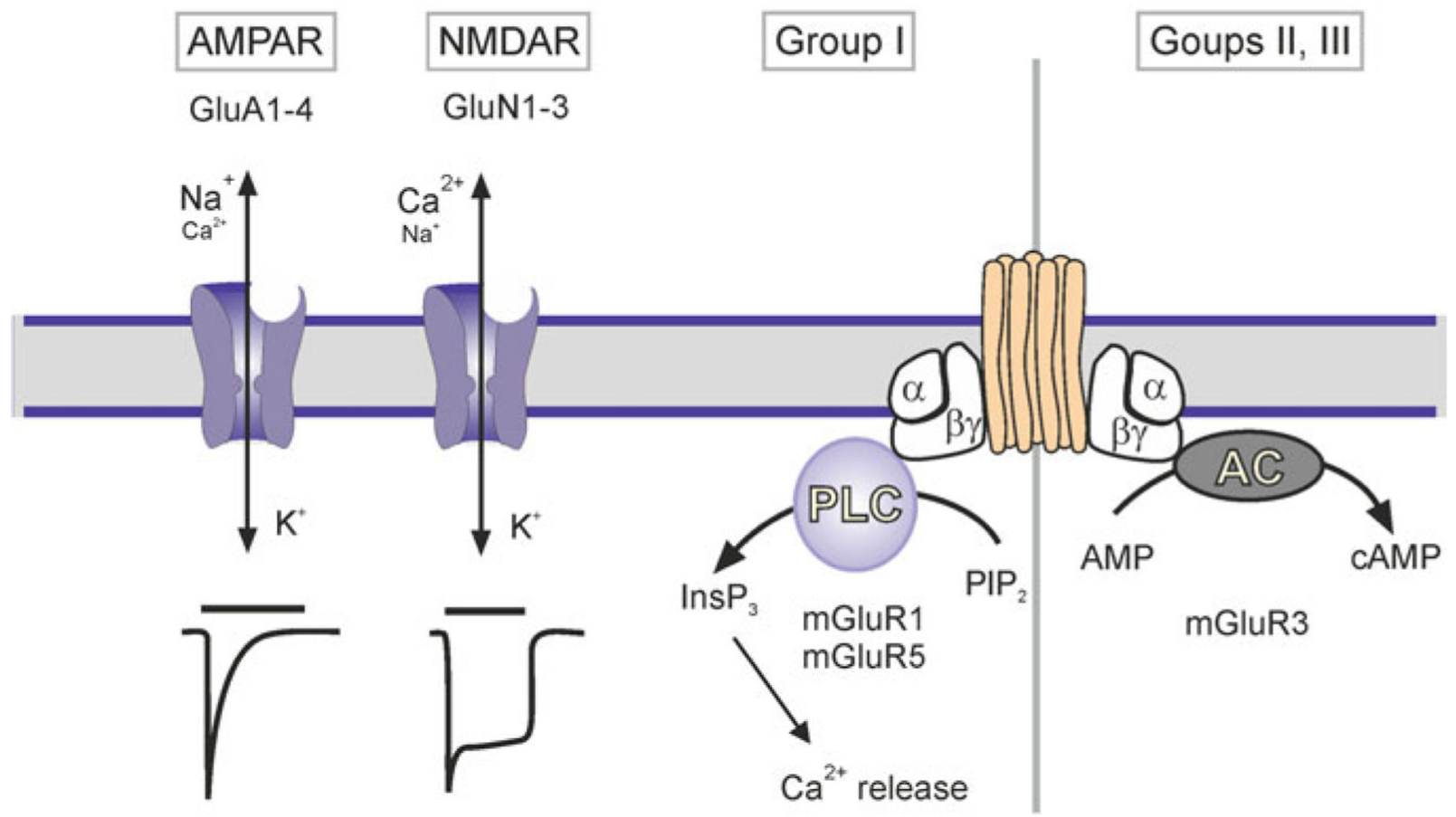

Fig. 3.7.

Classes of glutamate receptors expressed in astrocytes. Current traces show a faster time course for AMPAR than NMDAR. AC, adenylyl cyclase; AMP, adenosine monophosphate; cAMP, cyclic AMP; $\mathrm{InsP}_{3}$, inositol 1,4,5-trisphosphate; $\mathrm{PIP}_{2}$, phosphatidylinositol 4,5bisphosphate; PLC, phospholipase C. Modified from [406] 


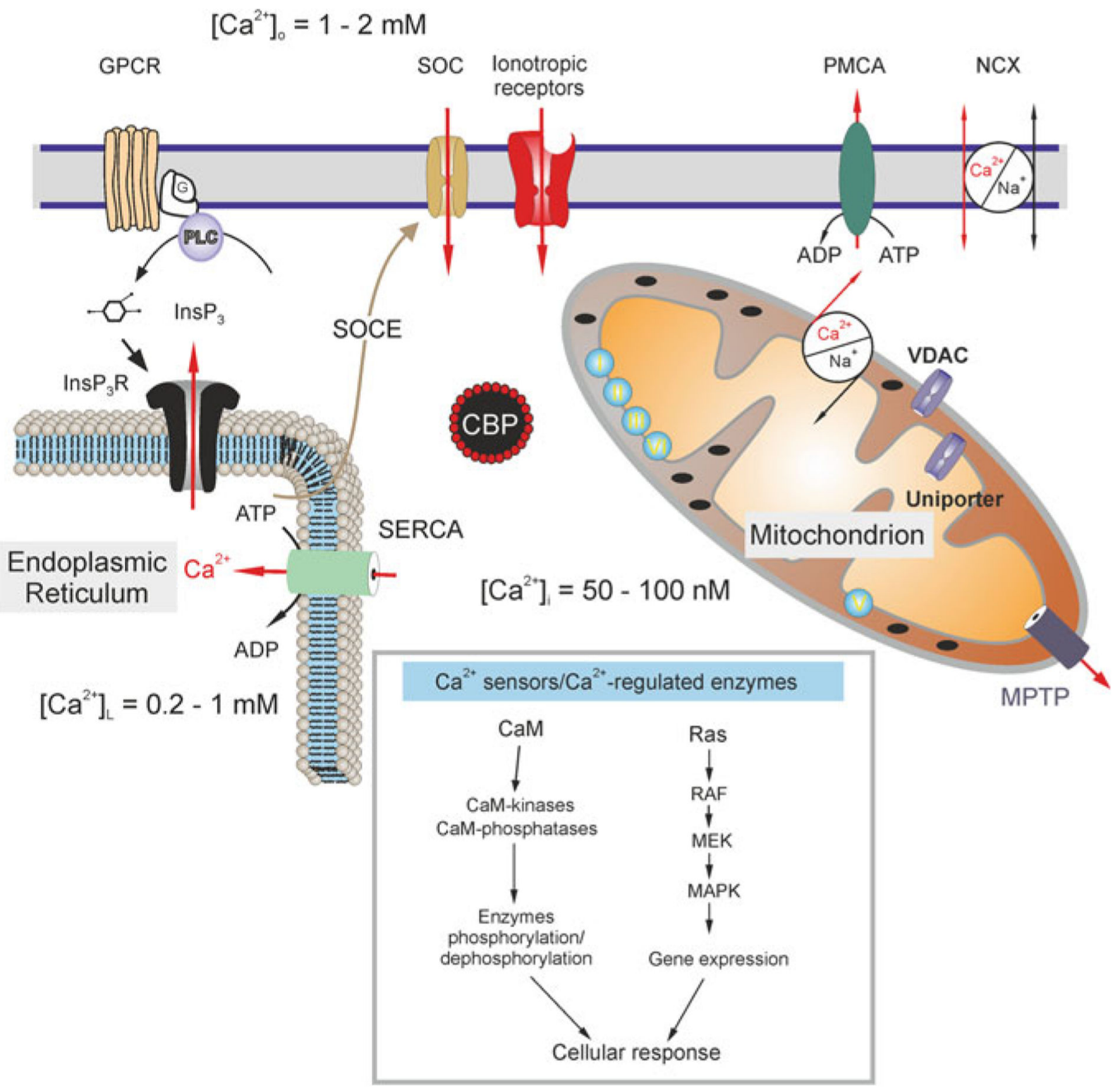

Fig. 3.8.

Calcium distribution and calcium signalling cascades in intracellular compartments. Stimuliinduced increases in $\left[\mathrm{Ca}^{2+}\right]_{\mathrm{i}}$ could be caused by the entry of $\mathrm{Ca}^{2+}$ from the extracellular space through ionotropic receptors or store-operated channels (SOC). Plasmalemmal $\mathrm{Ca}^{2+}$ pumps/ATPases (PMCA) can extrude cytosolic $\mathrm{Ca}^{2+}$, while the plasmalemmal sodiumcalcium exchanger $(\mathrm{NCX})$ can operate in both directions depending on intercellular $\mathrm{Na}^{+}$ concentration and membrane potential. An additional source of $\mathrm{Ca}^{2+}$ is available from the ER internal store that possesses inositol 1,4,5 trisphosphate $\left(\mathrm{InsP}_{3}\right)$ receptors, which can be activated by the activity of metabotropic G-protein coupled receptors (GPCRs) and phospholipase C (PLC). The ER store is (re)filled by the activity of the store-specific $\mathrm{Ca}^{2+}$ ATPase (SERCA). Cytosolic $\mathrm{Ca}^{2+}$ levels can be affected by a variety of cytosolic $\mathrm{Ca}^{2+}$ binding proteins (CBPs) and by the action of mitochondria. A negative membrane potential exists across the inner mitochondrial membrane. Mitochondrial $\mathrm{Ca}^{2+}$ uptake occurs through 
voltage-dependent anion channels (VDACs) present in the outer membrane and by the uniporter in the inner membrane as the electrochemical gradient drives $\mathrm{Ca}^{2+}$ into the matrix, while free $\mathrm{Ca}^{2+}$ exits the mitochondrial matrix through the mitochondrial $\mathrm{Na}^{+} / \mathrm{Ca}^{2+}$ exchanger and transient opening of the mitochondrial permeability transition pore (MPTP). Concentrations of free $\mathrm{Ca}^{2+}$ in different compartments are indicated on the scheme. Inset shows various $\mathrm{Ca}^{2+}$ effector molecules, sensors and enzymes. CaM, calmodulin; RAF, Rapidly Accelerated Fibrosarcoma, MAPK, mitogen-activated protein kinase (MAPK), MEK, MAPK kinase. Modified from [413] 


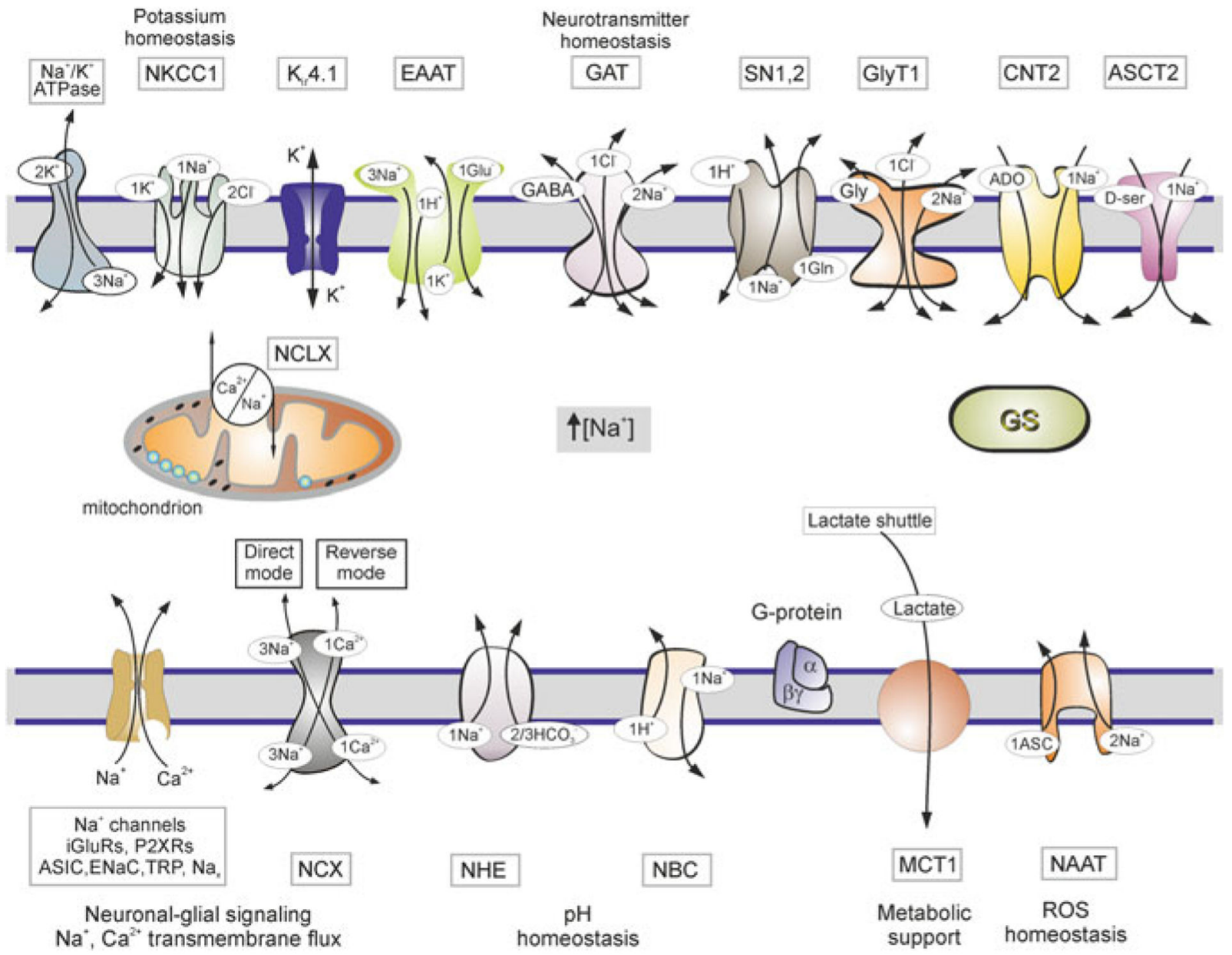

Fig. 3.9.

Molecules of $\mathrm{Na}^{+}$homeostasis and targets of $\mathrm{Na}^{+}$signalling in astroglia. Schematic diagram showing receptors and transporters involved in and sensitive to changes in $\left[\mathrm{Na}^{+}\right]_{\mathrm{i}}$ and their relations to main homeostatic functions of astroglia. Abbreviations ASCT2, alanineserinecysteine transporter 2; ASIC-acid sensing ion channels; CNT2, concentrative nucleoside transporters; EAAT-excitatory amino acid transporters; ENaC-epithelial sodium channels; GAT-GABA transporters; GS-glutamine synthetase, GlyT1-glycine transporter. iGluRsionotropic glutamate receptors; $\mathrm{Na}_{\mathrm{x}}-\mathrm{Na}^{+}$channels activated by extracellular $\mathrm{Na}^{+}$; NAAT-Na ${ }^{+}$-dependent ascorbic acid transporter; $\mathrm{NBC}-\mathrm{Na}^{+} / \mathrm{HCO}_{3}{ }^{-}$(sodium-bicarbonate) cotransporter; NCX-Na ${ }^{+} / \mathrm{Ca}^{2+}$ exchanger; NCLX-mitochondrial $\mathrm{Na}^{+} / \mathrm{Ca}^{2+}$ exchanger; NHE$\mathrm{Na}^{+} / \mathrm{H}^{+}$exchanger; NKCC1-Na ${ }^{+} / \mathrm{K}^{+} / \mathrm{Cl}^{-}$cotransporter, MCT1-monocarboxylase transporter 1; P2XRs-ionotropic purinoceptors; SN1,2-sodium-coupled neutral amino acid transporters which underlie exit of glutamine; TRP-transient receptor potential channels. Reactive oxygen species (ROS). Modified from [413] 